\title{
Science Mapping: A Scientometric Review on Resource Curses, Dutch Diseases, and Conflict Resources during 1993-2020
}

\author{
Chi-Swian Wong (D)
}

Citation: Wong, C.-S. Science

Mapping: A Scientometric Review on Resource Curses, Dutch Diseases, and Conflict Resources during 1993-2020. Energies 2021, 14, 4573. https:// doi.org/10.3390/en14154573

Academic Editor: David Mares

Received: 23 June 2021

Accepted: 22 July 2021

Published: 28 July 2021

Publisher's Note: MDPI stays neutral with regard to jurisdictional claims in published maps and institutional affiliations.

Copyright: (C) 2021 by the author. Licensee MDPI, Basel, Switzerland. This article is an open access article distributed under the terms and conditions of the Creative Commons Attribution (CC BY) license (https:/ / creativecommons.org/licenses/by/ $4.0 /)$.
Department of Political Science, Nanjing University, Nanjing 210023, China; mg1906009@smail.nju.edu.cn; Tel.: +86-18613620675

\begin{abstract}
Over the past few decades, the wealth of Africa has not made African wealthy. There is a voicing that Africa is cursed, whether richly poor or poorly rich. Sub-Saharan Africa is commonplace for political turbulence, as well as humanitarian and economic misery. In such a catastrophic situation, political economics studies have focused on the Resource Curses, Dutch Diseases, and Con-flict Resources in this area. A systematic scientometric analysis of this field would be beneficial but is currently lacking in the academic literature. Using VOSviewer and CiteSpace, this review fills the void by analyzing the 1783 articles published in the WoS SSCI Collection between 1993 and 2020 on the "Resource Curses", "Dutch Diseases", and "Conflict Resources". The author dis-cusses recent papers with disruptive potential, references with the most robust citation explora-tions, and cooperation networks between authors and institutes. Three hotspots were detected: the causes and effects of the Resource curses; the interaction among the Resource Curses, Dutch Diseases, and Conflict Resources; the factors that affect rent collection and regime resilience. While the literature on the "Resource curse" and "Dutch Disease" has been around longer, studies on "Conflict Resources" are picking up quickly. Conflict Resources were characterized by active citation exploration keywords and multiple active co-citation clusters, including possibly groundbreaking articles. There is a massive overlap between the three strings of literature, but each one has its emphasis.
\end{abstract}

Keywords: African countries; Dutch Diseases; Resource Curses; Conflict Resources; bibliometric analysis; CiteSpace

\section{Introduction}

The research on how natural resources affect economic development is fascinating and interesting in political economics studies. Although early research on the resource curse found a clear negative relationship between natural resources and GDP growth, more recent research has found a positive connection between the two [1-5]. With several countries already reliant on unpredictable resource rentals, the effect of natural resources on economic development is a worrying high-stakes policy [6].

Over the past few decades, the wealth of Africa has not made African wealthy. Although Africa is rich in bauxite, uranium, coltan, gold, diamonds, oil, and other precious commodities, its people have long been among the world's poorest and most disappointed [7]. While a few countries in Sub-Saharan Africa are doing reasonably well, most are impoverished [8]. All seem to have an interesting reason for this unfortunate occurrence, including the Resource Curse, Dutch Disease, overwhelming corruption, inefficient political processes, mechanisms of injustice, selfish multinationals, shady local and external elites, inefficient or inadequate international aid agencies, outside military and imperial influences, and the emergence of a modern form of colonization led by actors such as China and Israel [9-16].

This review provides a scientometric analysis of the Resource Curses, Dutch Diseases, and Conflict Resources studies from 1993 to 2020, as well as the historical research accomplishments in this field, possibly presenting guidelines for decision-makers through 
institutes, industries, and scholars in coping with the emerging unpredictable African political unrest. The rapidly increasing branch of analysis considered "the science of science" that seeks fundamental and domain-specific developments in large-scale data on the advancement of sciences is helpful to demonstrate how studies and researchers are associated [17].These specific clusters face a significant challenge in defining the search criterion for relevant literature. A series of terms, such as "Resource Curses", "Dutch Disease", "Conflict resource", "the paradox of plenty", "resource trap", "conflict diamond", "blood diamond", "Banana republic", "crony capitalism", and "conflict mineral", could represent such a political economics phenomenon and the unpredictable socio-political turmoil. The author selected three similarly related terms- "Resource Curse", "Dutch Disease", and "Conflict resource"-and applied them as search terms to retrieve bibliographic documents from the Web of Science (WoS) Social Science Citation Index database after careful consideration.

The remainder of this article is organized as follows: In Section 2, the author introduces three theoretical concepts: Resource Curses, Dutch Diseases, and Conflict Resources. Section 3 discusses data processing and analysis techniques. Section 4 presents the quantitative analysis, including discipline bases, journal and institutional influence, and productive mapping of countries/regions. Section 5 deals with co-occurrence analysis from discipline co-existence, mainstream journals, keyword frequency analysis, and reference co-citation analysis. Limitations of the results and conclusions are addressed and discussed in Sections 6 and 7.

\section{Theoretical Concepts}

\subsection{Resource Curse}

Richard Auty coined the term "Resource Curse" in 1993 to explain how countries with abundant mineral resources could not utilize the godsend to feed their economies and, counterintuitively, have weaker economic development than countries with fewer natural resources [18]. It seems that striking gold or locating oil would carry immediate prosperity. Instead, it often results in violence, poverty, and corruption. Throughout history, natural resource wealth has resulted in less economic development in many countries. Government officials may mismanage or embezzle raw material mining revenue, or foreign corporations may siphon it off. The windfall would stifle investment in other sectors of the economy, raising the cost of properties and services [3].

For smaller and less diverse economies, volatile global commodity prices can determine the country's fiscal fate. Local people will be left with little but a degraded landscape as a legacy of their prosperity. This effect is recognized as the "Resource Curse" among economists and social scientists [19]. Government corruption may even be to blame for the Resource Curse [20]. When a large portion of a country's capital is concentrated in a few sectors, the regime may exploit its regulatory authority by awarding lucrative contracts in return for bribes [21]. With so much labor and money moving through a few businesses, most of the country's economy might be hurt [22].

Initially, "Resource Curse" was the only term selected because it perfectly described the new socio-political condition in some sub-Saharan African and middle east countries. There is a voicing that Africa is cursed-whether richly poor or poorly rich [23-25]. Auty [18] invented the term "Resource Curse" in 1993 to describe how mineral-rich states were reluctant to utilize their reserves to develop their economies. Ironically, these states showed slower economic prosperity than states with less abundant natural resources [18]. Jeffrey Sachs and Andrew Warner's leading research described a close association between natural resource abundance and slow economic development [26]. The term "Resource Curse" is also known as "resource trap" or "paradox of plenty." Therefore, the latter two terms are just other aspects of the "Resource Curse." However, the term "Resource Curse" is more prevalent in academics than "resource trap" or "the paradox of plenty", as revealed by the 948 articles on "Resource Curse" compared to just seven articles on "resource trap" 
and 15 articles on "the paradox of plenty." Hence, articles on "Resource Curse", "resource trap", and "the paradox of plenty" were grouped as the initial string of targeted literature.

\subsection{Dutch Disease}

Dutch Disease is an economic illness that is easy to contract but difficult to cure [27]. The term was coined in 1977 by The Economist to characterize the Dutch economy's woes [28]. Dutch Disease occurs as the production of raw materials (such as oil and gas) increases exponentially, leading other parts of the economy to struggle. When raw resources run out, the country returns to a more miserable status than before. Behzadan et al. (2017) [29] illustrated that the epidemic might be induced by unequal distribution of natural resources. Spending on non-tradable discretionary products and services grows disproportionately because of a resource boom. The workforce from other fields, such as the construction and manufacturing sectors, is depleted due to increased demand and opportunities in the oil and gas sector. As a result, demand in the construction and manufacturing industries sectors declines, not because they are expensive, but to not being a top priority in the short term [29].

Another worry is that, beyond the traditional Curse vs Disease distinction formulated by Larsen (2006) [30], many scholars appear reluctant to distinguish between "Dutch Disease" and the "Resource Curse" because of the distinction between the two terms is often meaningless [31-34]. Hence, articles on "Dutch Disease", "rentier state", and "petrostate" were grouped as representatives of the targeted literature's second string.

\subsection{Conflict Resource}

The term "Conflict resource" or "conflict commodity" first appeared in the late 1990s, relating to "blood diamonds" that were exploited to finance rebellions in Angola and Sierra Leone $[35,36]$. Then "conflict timber" was used to describe strife in Cambodia and Liberia [37,38]. Armed wars, human rights violations, and crime were aroused and funded using Conflict Resources [39]. According to Global Witness, Conflict Resources are "natural resources whose systematic misuse and trade in a conflict contribute to, benefit from, or result in severe human rights abuses, individual rights law offences, or violations because of international crimes" [40]. Access to external markets determines a conflict's party's ability to exploit natural resources. They will no longer intensify or perpetuate disputes as they cannot benefit from resource production. Even though natural resource revenues are now widely acknowledged as providing the supplies for the war in Angola, Cambodia, Liberia, and Sierra Leone, the international community has not addressed the problem correctly and regularly. Blood diamond extraction and distribution, related to "conflict diamonds", is a more well-known phenomenon in almost similar circumstances [41-43].

The "Conflict resource" is an essential consideration because it is connected to both the "Resource Curse" and "Dutch Disease". On the one hand, "Conflict resource" is thought to trigger "Dutch Disease" and the "Resource Curse [44]". "Conflict Resources" incite war, from the Central Asian pipelines to shipping lanes of the South China Sea and from the Nile delta to the oil fields of Saudi Arabia [45]. Resource wars characterize the growing impact of resource scarcity on a countries' military policies. Hence, articles on "Conflict resource", "resource conflict", "blood diamond", and" conflict diamond" were grouped as the targeted literature's third string.

\section{Research Methodology}

\subsection{Methods}

In brief, the search query was implemented to examine the literature on "Resource Curse", "Dutch Disease", and "Conflict resource" jointly and separately. The author would illustrate how the three strings of literature progressively converge and parallel one another using visual scientific analysis, thereby exposing intellectual relationships among the three series of terms from a new viewpoint not previously disclosed. To the extent of the author's knowledge, bibliometric analyses have never been conducted on "Resource Curse", "Dutch 
Disease", or "Conflict resource." This review reveals how scientometric analysis aids us in becoming quickly acquainted with a particular research domain and evaluating the similarly associated research divisions using bibliometric research. This article is structured to provide a historical (1993-2020) scientometric study of "Resource Curse", "Dutch Disease", and "Conflict resource" while disentangling the dynamic interactions among the three terms using bibliometric analysis.

Using the Web of Science SSCI Core Collection database to collect bibliographic documents, as previously described, the search query contained the terms "Resource Curse/resource trap/the paradox of plenty", "Dutch Disease/rentier state/petrostate", and "Conflict resource/resource conflict/conflict diamond/blood diamond". The documents" "title", "abstract", "author keywords", and "keyword plus" were all included in the WoS Core Collection's "TS" (Topic). In its current set, the "keyword plus" search query always fails to adequately reflect an article's contents to much the same extent as the "title", "abstract", and "author keyword" parameters. However, since "keyword plus" is not included in the WoS Core Collection, searching the "title" solely would skip a ton of related literature.

As an unfortunate byproduct of collecting enough related literature as necessary, noise does not influence the ultimate results. Only publications, keywords, references, authors, institutes, and countries with a significant enough occurrence or citation frequency may occur in the ultimate graphs or tables. This norm is typically not met by irrelevant bibliographic documents, mainly when the literature volume is sufficiently large. Overall, this data collection approach has followed Chen's (2017) [46] spirit: "It is more realistic and effective to completely miss an insignificant branch than to keep optimizing the initial subject search query before all apparent irrelevant topics are removed".

Table 1 shows what took place when the author narrowed the type of publication to "Article" or "Review" and used "English" as the language. The author obtained 962 articles for "Resource Curse/resource trap/the paradox of plenty", 655 articles for "Dutch Disease/rentier state/petrostate", and 348 articles for "resource conflict/Conflict resource/conflict diamond/blood diamond", and 1783 articles for the unified science string. The framework and pathology of this field can be presented through mapping intelligence structures. This is a kind of scientometric analysis that focuses on scientific intelligence [47].

Table 1. Results from a selection of search methods.

\begin{tabular}{|c|c|c|c|}
\hline Set & Results & Different Topics & Common Searching Term \\
\hline$\# 1$ & 964 & $\begin{array}{c}\mathrm{TS}=(\text { "resource curse *" OR "resource trap *" OR } \\
\left.\text { "the paradox of plent }{ }^{* \prime)}\right)\end{array}$ & Language: (English) \\
\hline$\# 2$ & 655 & $\begin{array}{c}\mathrm{TS}=(\text { "Dutch disease *" OR "rentier state *" OR } \\
\text { "petrostate *") }\end{array}$ & $\begin{array}{c}\text { Document Type: (Article or } \\
\text { Review) }\end{array}$ \\
\hline$\# 3$ & 348 & $\begin{array}{l}\text { TS = ("conflict resource *" OR "resource conflict *" } \\
\text { OR "conflict diamond *" OR "blood diamond *") }\end{array}$ & Indexs = SSCI \\
\hline$\# 4$ & 1783 & $\begin{array}{l}\text { TS = ("resource curse *" OR "resource trap *" OR } \\
\text { "the paradox of plent *" OR “Dutch disease *" OR } \\
\text { "rentier state *" OR "petrostate*" OR "conflict } \\
\text { resource *" OR "resource conflict" OR “conflict } \\
\text { diamond *" OR "blood diamond *") }\end{array}$ & Timespan = 1993-2020 \\
\hline
\end{tabular}

There are many bibliometric tools out there right now; CiteSpace, VOSviewer, Bibexcel, and CoPalRed are only a few examples. Social network analysis has been conducted using at least 55 software (programs) available on the insna website platform [48]. CiteSpace, VOSviewer, and Biblioshiny were utilized to perform analysis in this article. VOSviewer program was first used to do co-authorship and co-citation research. Institutional and national dimensions of co-authorship research were both considered. The three parts of the co-citation review were reference co-citation, publication co-citation, and author 
co-citation. The author used CiteSpace to collect co-occurrence keyword clusters to perform a high-frequency keyword social network research. The most widely utilized CiteSpace was applied to analyze the high-occurrence keyword networking connection in this article. Biblioshiny R software was used to track region/country publication geography charts. An illustration of an integrated workflow in science mapping analysis is given in Figure 1.

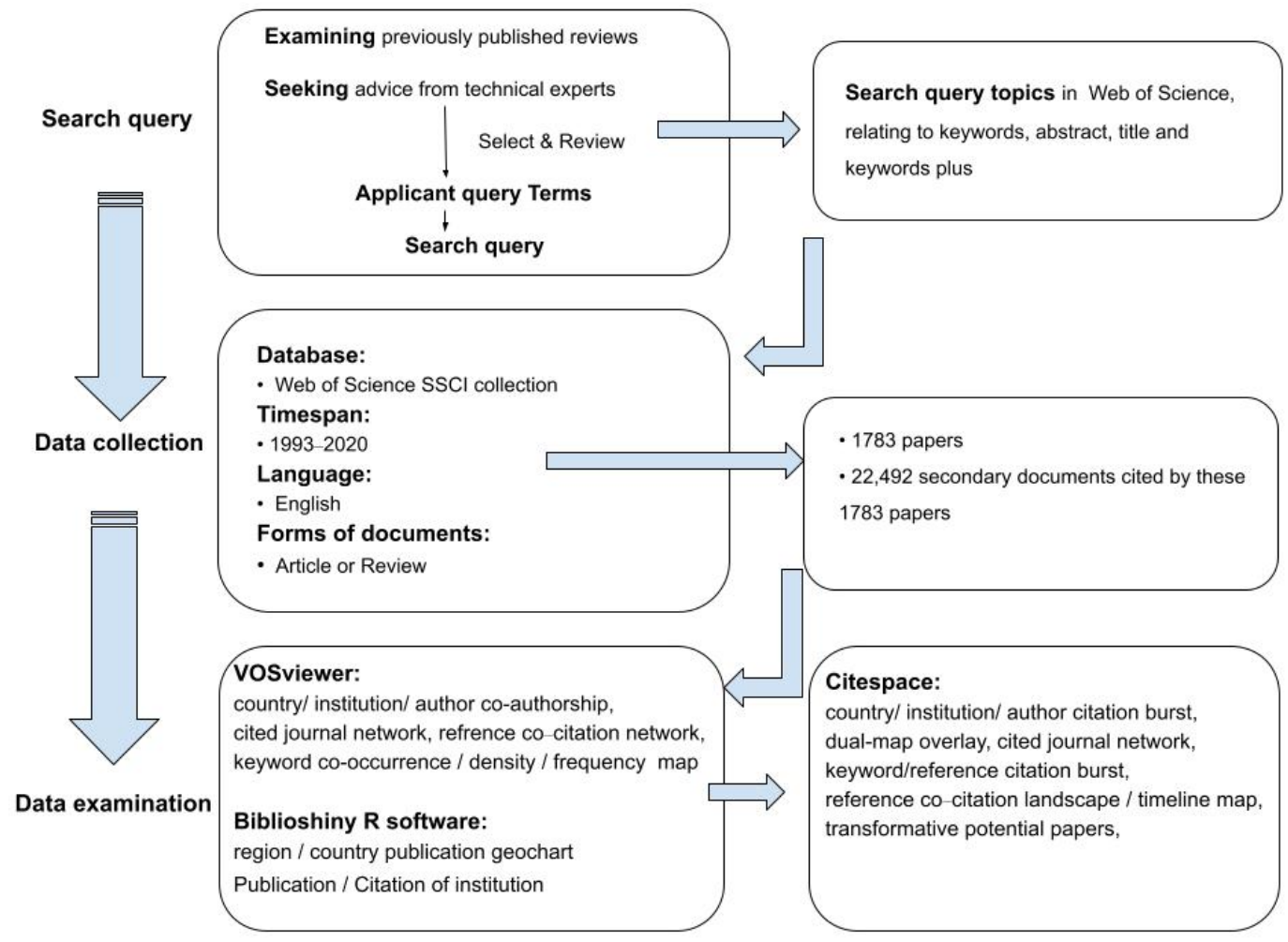

Figure 1. Integrated research mapping workflow.

\subsection{Yearly Distribution}

Figure 2 depicts the annual distribution of 1783 articles from 1993 to 2020. It is split into three stages. During Step I (1993-2004), the number of annual articles was seldom over 15. There were a few exceptions in 1998, 2001, and 2004, mainly attributed to Dutch Disease literature. During Step II (2005-2010), the number of articles steadily increased from 46 in 2005 to 58 in 2007.

The period in Step III (2011-present) reveals rapidly increasing publications in the Resource Curses, Dutch Diseases, and Conflict Resources-related domain, especially in the last decades.

Although it is tempting to believe that research on Resource Curses, Dutch Diseases, and Conflict Resources-related domain has become more popular, this shift should be recognized in the light of broader scholarly publication trends. Publishing trends across the whole scientific field have increased significantly [49]. Similar increases in publishing growth have been found in other scientific-metric studies on politics [50-52]. As a result, it is unclear if the improved Resource Curses, Dutch Diseases, and Conflict Resources-related study outputs reflect this domain's increased academic importance if these phenomena are a function of increased relevance in political economy or sociology, or whether trends result from internal academic dynamics. 


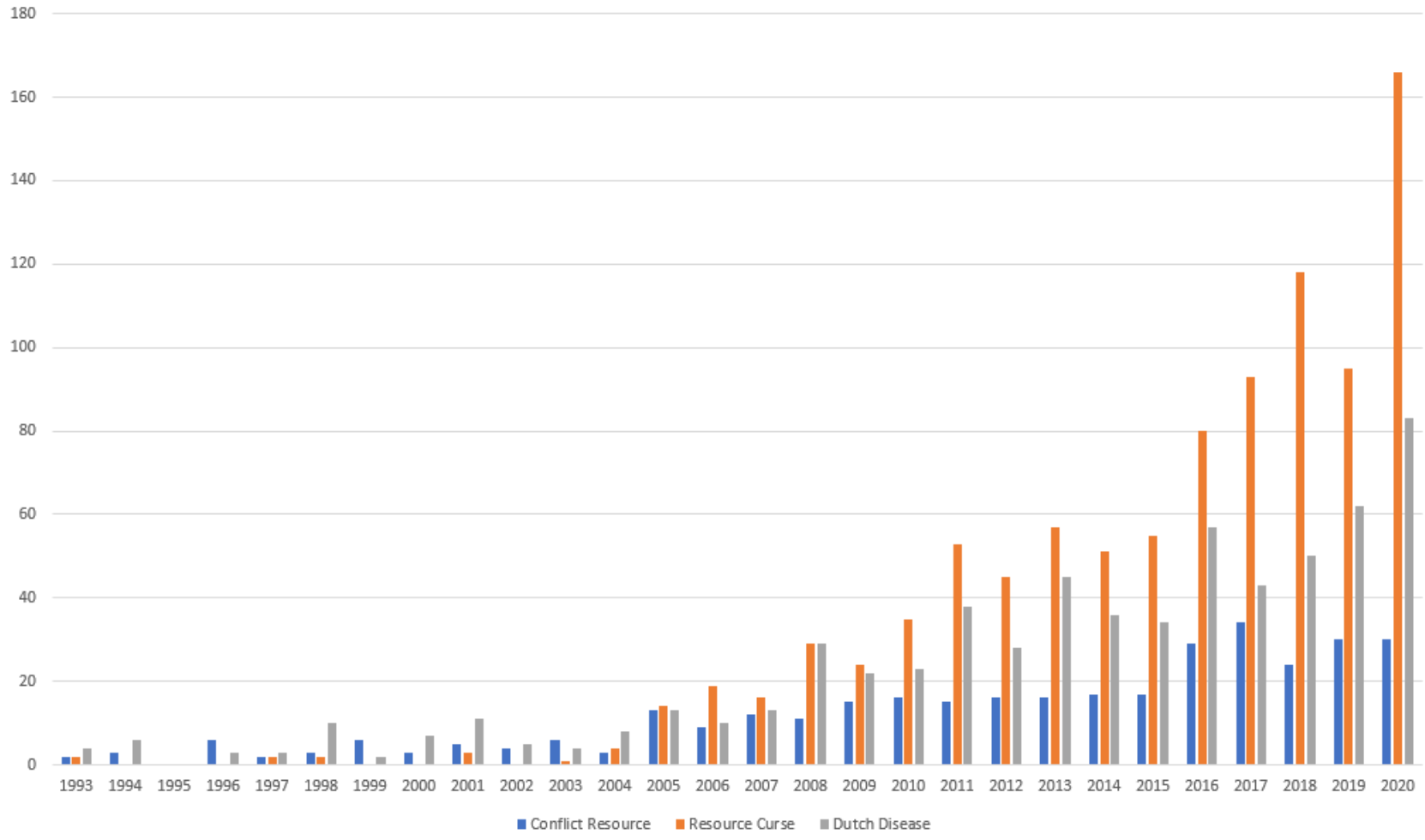

Figure 2. Annual publication distribution 1993-2020 (collected on 22 February 2021).

The effect of African states' turmoil and instability has been significantly strengthened by globalization. Figure 2 depicts the distribution of the three literature strings separately. The "Dutch Disease" analysis first emerged in 1993 and now has the second significant publication number. The "Resource Curse" literature, which first overpasses the Dutch Disease literature in 2006 for yearly publication number, and overpasses Dutch Disease literature for the total publication number in 2011, had the most annual publications in following years and now has the most significant total article number. The "Conflict resource" literature started in 2001 and has developed steadily since then, especially in the 2010s. Conflict resource literature reached its peak in 2016 (14 articles) and then ceased increasing.

Specifically, in 2018, literature on the Resource Curses could sustain a steady growth pace. The other two literature strings failed; In terms of yearly publications, the literature on Resource Curses exceeded Dutch Diseases literature in 2006. In 2020, 178 papers published on the Resource Curses, almost double the number of papers published of the other two literature strings. Resource Curse topics other than Dutch Disease have recently piqued attention from academics.

For bibliometric research, three types of excellent applications were used. VOSviewer (1.6.16) is used for country/institute/author co-authorship, cited journal network, reference co-citation network, and keyword co-occurrence frequency map. Biblioshiny $\mathrm{R}$ software is used to track region/country publication geography charts. CiteSpace (5.7. R4) is used to track country/institute/author citation exploration, reference co-citation landscape/timeline map, and transformative potential articles.

\section{Analysis of Productive Country/Institute/Researcher}

\subsection{Productive Regions/Countries}

The line's thickness represents the tightness of relationships between countries or areas. The author set a threshold of 5, and 60 countries met the criteria. The results are represented in Figure 3. We can find a strong US focus and internationalization of the research. 


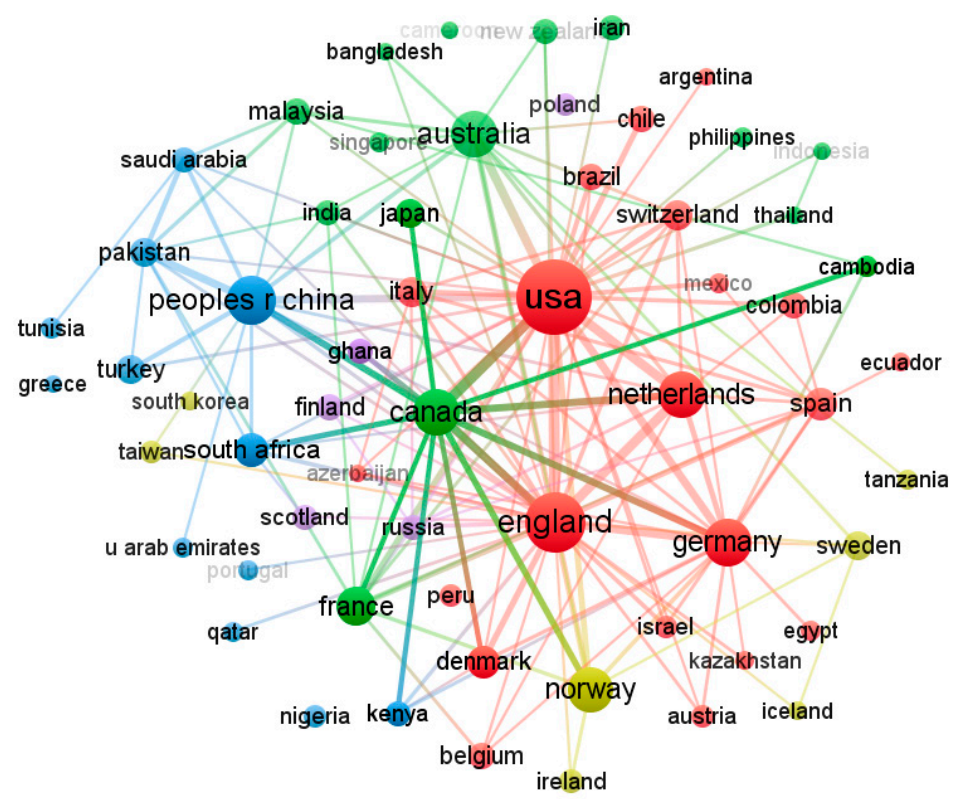

Figure 3. Network of country co-authorship.

This is not specific to the subject but more of a general development in sciences in recent years. In the vast majority of bibliometric analyses and articles, US scholars are consistently ranked first in total articles numbers and total citation frequencies. The total articles and total citation frequencies from UK scholars often ranked second [53-72].

The USA and the UK have the most critical node, showing that scholars from both countries have a substantial level of collaborative engagement, preceded by Australia, Germany, Canada, China, and the Netherlands. The above Figure 3 proves that multinational co-authors have a high number of publications in these countries. The 60 countries are divided into five clusters; each comprises one color. For instance, the USA, the Netherlands, the UK, Germany, Switzerland, and Colombia belong to the red group. Pakistan, China, Turkey, South Africa, Kenya, and Tunisia are part of the blue group. Australia, Canada, France, Japan, Malaysia, Philippines belong to the green group. Their geographical locality determines the collaboration of authors from various countries. Likewise, through the thickness of the frontier between countries, it can be noted that the United States collaborates closely with the UK and Canada. Another phenomenon that cannot be ignored is that the US, UK, and Canada links are somewhat unsurprising given more significant academic trends. Moreover, it is tempting to conclude that this trend also recommends that international conferences and research visits become more popular.

On the contrary, it may be a causal factor, and there is no indication that international conferences and research visits are becoming more popular. Although North-South cooperation is necessary, it has to be admitted that there is less collaboration between researchers in Western resource extracting countries and scholars in non-Western resource extracted countries, which can be shown in Figure 3.

I wish to understand better the topics published by each country over the past 27 years. Figure 4 below depicts the number of publications generated by various countries from 1993 to 2020. The United States (574) and the UK (275) have the most publications, accompanied by Australia (132). 


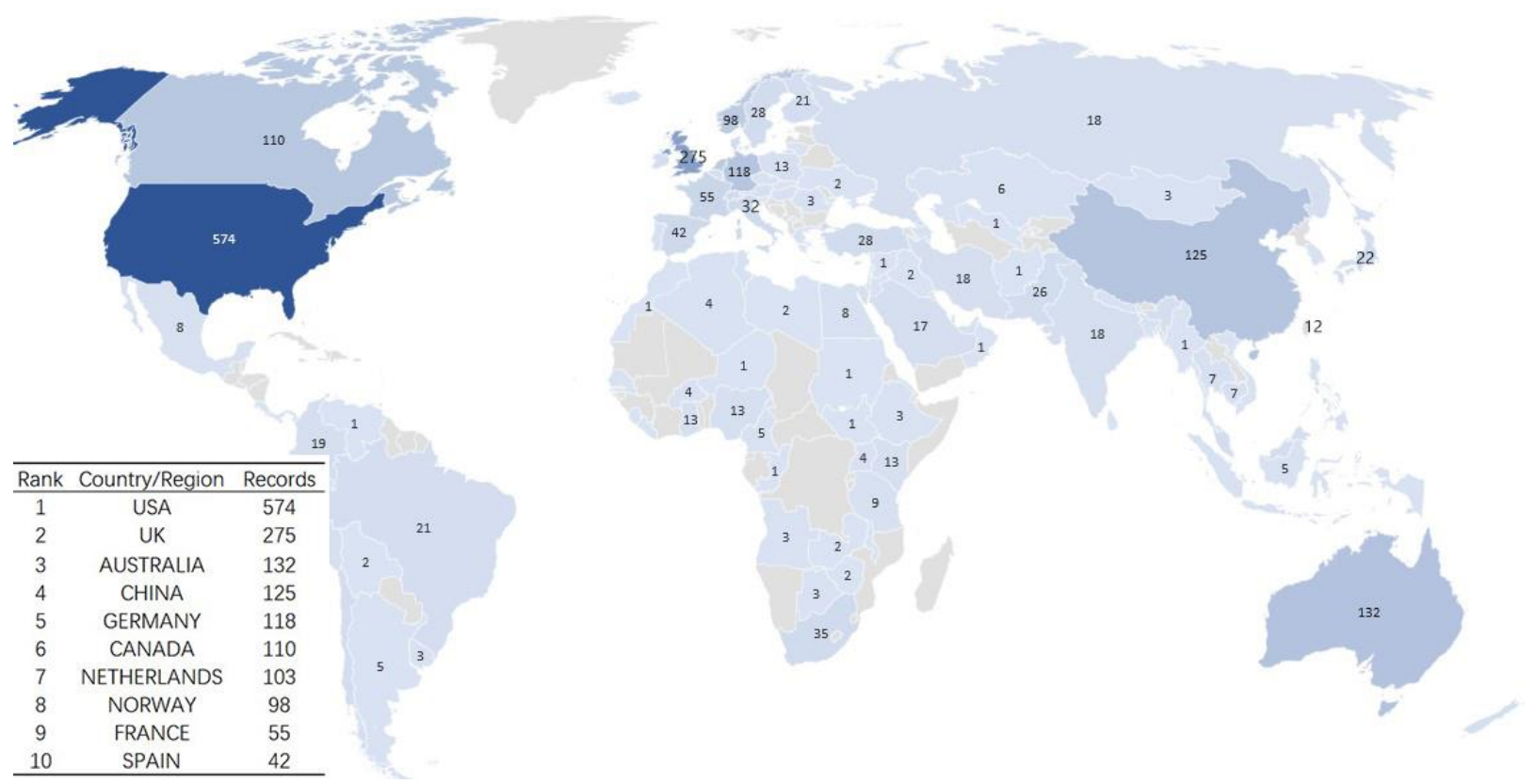

Figure 4. Different countries with publications.

From 1993 to 2020, Figure 5 above reveals the annual number of publications among the top ten countries, including one Asian, two North American, six European, and one Oceania. Following 1993, American academia became more involved in the Resource Curses/Dutch Diseases/Conflict Resources study.

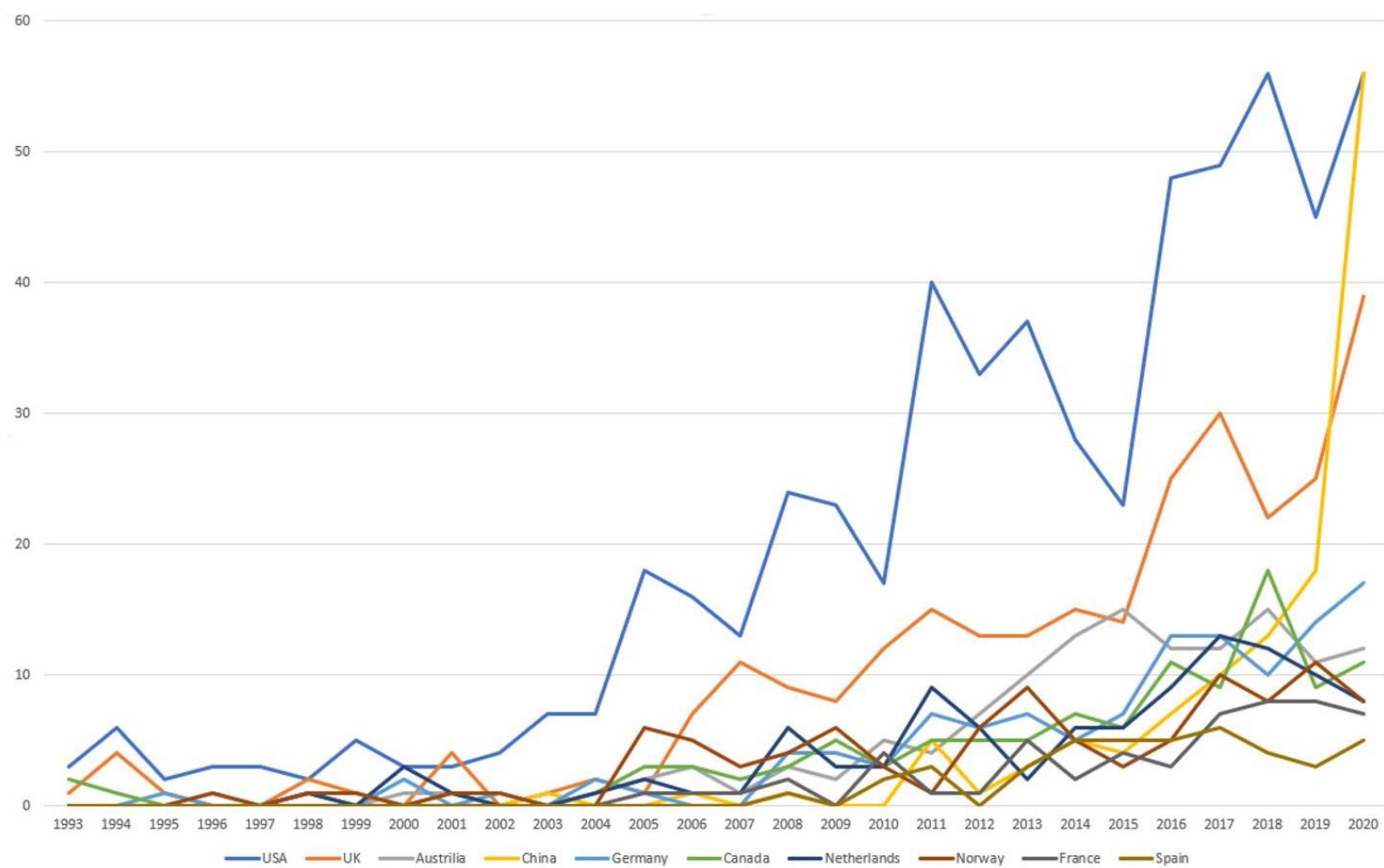

Figure 5. Annual trends in publications from top 10 countries.

However, the quantity of researchers remains limited, resulting in a few publications. Following the example of the United States, the UK and Australia conducted work in this field. Since 2007, an increasing number of countries have recognized the significance of this field. The amount of countries researching this field is growing, as the amount of 
articles in this field. In addition, between 2007-2020, the number of Resource Curses / Dutch Diseases/Conflict Resources publications has the same steady growth pattern in those ten countries. Another fascinating phenomenon is that China scholars' publications overgrow recent years and surpass the USA in 2020. As conditions for international collaboration have improved, the number of Resource Curses publications in different countries will rise. Figure 6 lists the discoveries got from CiteSpace for countries with occurrence explorations. With a strength of 13.38, the exploration from the USA is the most dynamic. From the late 1990s to the early 2000s, scholars in the United States handled the advancement of research on "Resource Curse", "Dutch Disease", and "Conflict resource". Pakistan and Saudi Arabia have been emerging in recent years, and their booms are still underway.

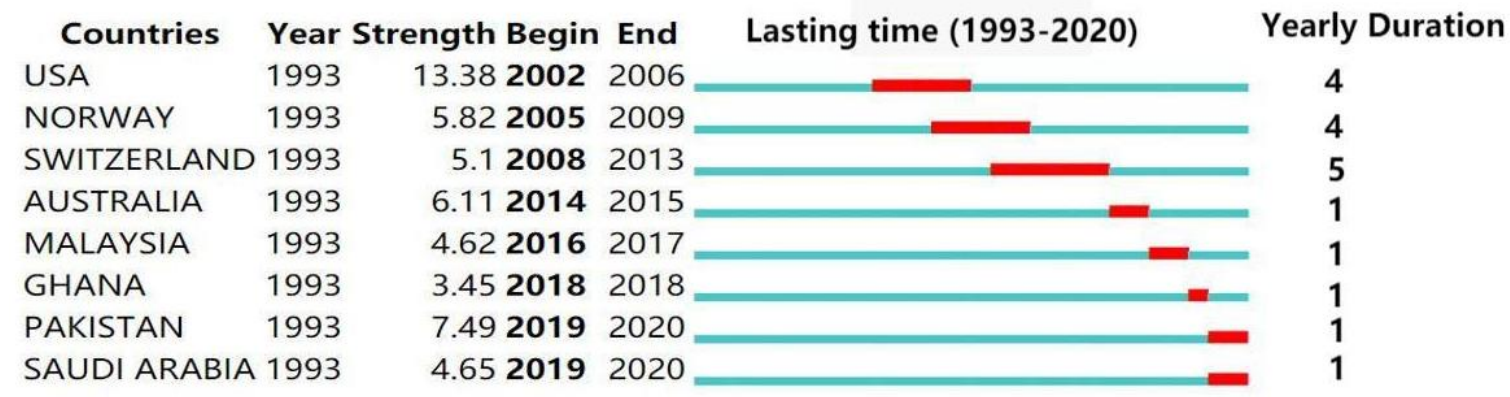

Figure 6. Countries with occurrence explorations during 1993-2020.

\subsection{Productive Institutes/Organizations}

For new publishers, the distribution of influential institutes of Resource Curse research is critical. Table 2 illustrates the number and distribution of the top 20 institutes' publications, with the University of Oxford (52) having the most published outputs, followed by the Norwegian University of Science and Technology (28), The Australian National University (26), the World Bank (26) and The University of British Columbia (23). Four of the top 10 institutes are European institutes, two are American institutes, and two are international organizations. The citation numbers and distribution of the top 20 institutes can also be seen in Figure 7, showing that are in the USA-Int Peace Research Institute (1452), Harvard University (210), University Oslo (1224), and UCLA (1188), two are in the Netherlands- Vrije University Amsterdam (1240), and-Tilburg University (939); and two are in Norway- Norwegian University of Science and Technology (2677), and Chr. Michelsen Institute (843)).

From Figure 7, we can identify some meaningful results: Although the World Bank had a comparably higher publication number, it featured lower total citation records. American scholars have done well in terms of publication quality.

\begin{tabular}{lrrr}
\multicolumn{1}{c}{ Institutions } & \multicolumn{1}{c}{ Year Strength Begin End } & Lasting time (1993-2020) & Yearly Duration \\
Norwegian Univ Sci \& Technol 1993 & 7.51998 & 2008 & 10 \\
Tilburg Univ & 1993 & 3.792005 & 2012 \\
Int Monetary Fund & 1993 & 3.742008 & 2013 \\
Chr Michelsen Inst & 1993 & 4.9620092013 & $\mathbf{5}$ \\
Univ Oxford & 1993 & 4.5620092012 & 4 \\
\hline
\end{tabular}

Figure 7. Institutes with occurrence explorations during 1993-2020. 
Table 2. The top 20 institutes with documents and citations.

\begin{tabular}{|c|c|c|c|c|c|}
\hline Rank. & Institutes & Records & Institutes & Citations & TCS \\
\hline 1 & $\begin{array}{c}\text { Norwegian University of Science and } \\
\text { Technology }\end{array}$ & 52 & University of Oxford & 2677 & 731 \\
\hline 2 & The Australian National University & 28 & $\begin{array}{c}\text { Stockholm International Peace Research } \\
\text { Institute }\end{array}$ & 2328 & 790 \\
\hline 3 & World Bank & 26 & Harvard University & 1452 & 324 \\
\hline 4 & The University of British Columbia & 26 & Vrije Universiteit Amsterdam & 1253 & 210 \\
\hline 5 & International Monetary Fund & 23 & University of Oslo & 1240 & 475 \\
\hline 6 & Harvard University & 22 & University. California Los Angeles & 1224 & 378 \\
\hline 7 & The University of Queensland & 21 & Tilburg University & 1188 & 267 \\
\hline 8 & University of Sussex & 21 & University of Iceland & 939 & 397 \\
\hline 9 & University of Amsterdam & 20 & CMI (Chr. Michelsen Institute) & 870 & 179 \\
\hline 10 & Erasmus University Rotterdam & 19 & University of Sussex & 843 & 180 \\
\hline 11 & University of Oslo & 18 & The University of British Columbia & 792 & 186 \\
\hline 12 & University of Wisconsin & 18 & Stanford University & 734 & 135 \\
\hline 13 & Vrije Universiteit Amsterdam & 18 & Columbia University & 721 & 108 \\
\hline 14 & The Ohio State University & 18 & The University of Manchester & 695 & 132 \\
\hline 15 & Tilburg University & 16 & University of Wisconsin & 675 & 86 \\
\hline 16 & London School of Economics & 16 & World Bank & 622 & 61 \\
\hline 17 & University of Cambridge & 15 & Wageningen University \& Research & 571 & 268 \\
\hline 18 & University of California, Berkeley & 15 & University of Amsterdam & 555 & 234 \\
\hline 19 & Leiden University & 14 & NYU & 472 & 143 \\
\hline 20 & & 13 & & 440 & 140 \\
\hline
\end{tabular}

TCS $=$ total connection strength.

Geographical locality is one of the most compelling reasons for cooperation between research entities. Research collaboration is widespread in universities from varied countries working on this research. The author could verify which institutes have caught up in this research domain using CiteSpace to identify institutes with occurrence explorations. As seen in Figure 7, the Norwegian University of Science and Technology's explorations are most vigorous (7.5), with the most prolonged duration (16 years).

As opposed to other study fields, publications and cumulative citations of this theme are considerable. To better understand how academic institutes work together, VOSviewer was utilized to build a network framework of 29 research institutes' coauthorship (Figure 8); since the collected database contained 2024 research institutes. The author set the threshold at 10, which resulted in VOSviewer splitting institutes into five clusters, each with a specific color. Oxford University, for example, collaborates often with the Vrije University Amsterdam, while Harvard University cooperates with the Norwegian University of Science and Technology.

It is helpful to discuss how very productive academics shape the reputation of their institutes. As can be seen in Table 3 and Figure 9, the total citation numbers of van der Ploeg were higher than Turkey and slightly less than China, which would rank van der Ploeg 11th among countries in terms of the total citation numbers. This phenomenon is similar for prominent institutions; for example, The University of Oxford can rival the vast majority of countries in terms of the total citation number. Productive academics shape the reputation of their institutes and vice versa. 


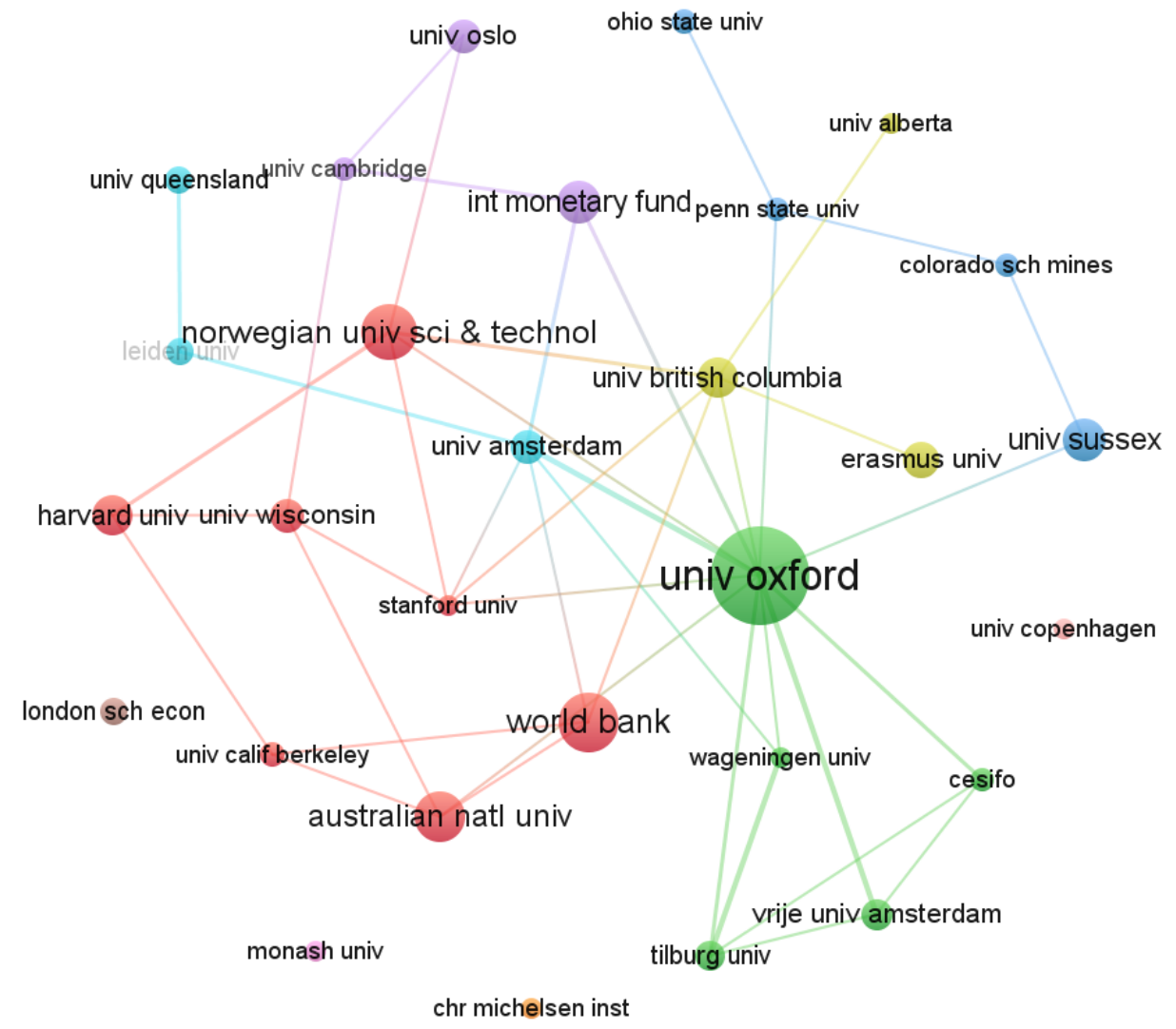

Figure 8. Institutes co-authorship network.

Table 3. Publication number by countries, institutions, and authors.

\begin{tabular}{|c|c|c|c|c|c|c|c|c|c|}
\hline Rank & Country & Documents & Citations & Organization & Documents & Citations & Author & Documents & Citations \\
\hline 1 & USA & 558 & 14,556 & Univ. Oxford & 46 & 2328 & Van Der Ploeg & 10 & 1059 \\
\hline 2 & England & 268 & 7235 & World Bank & 28 & 571 & Torvik Ragnar & 10 & 816 \\
\hline 3 & Australia & 132 & 2334 & $\begin{array}{l}\text { Norwegian Univ. } \\
\text { Sci \& Technol }\end{array}$ & 26 & 2677 & Sovacool Benjamin K. & 10 & 175 \\
\hline 4 & PR China & 125 & 1265 & $\begin{array}{l}\text { Australian Natl } \\
\text { Univ. }\end{array}$ & 24 & 213 & Kolstad Ivar & 9 & 825 \\
\hline 5 & Germany & 117 & 2284 & Univ. Sussex & 20 & 792 & Papyrakis Elissaios & 8 & 308 \\
\hline 6 & Canada & 108 & 1886 & $\begin{array}{l}\text { Int Monetary } \\
\text { Fund }\end{array}$ & 20 & 239 & Shahbaz Muhammad & 8 & 227 \\
\hline 7 & Netherlands & 103 & 3706 & Harvard Univ. & 19 & 1253 & $\begin{array}{c}\text { Lartey Emmanuel K. } \\
\text { K. }\end{array}$ & 8 & 220 \\
\hline 8 & Norway & 98 & 4726 & $\begin{array}{l}\text { Univ. British } \\
\text { Columbia }\end{array}$ & 19 & 734 & De Soysa Indra & 8 & 179 \\
\hline 9 & France & 55 & 1056 & Erasmus Univ. & 17 & 247 & Wiig Arne & 7 & 691 \\
\hline 10 & Spain & 42 & 788 & Univ. Oslo & 16 & 1224 & $\begin{array}{c}\text { Farzanegan } \\
\text { Mohammad Reza }\end{array}$ & 7 & 223 \\
\hline 11 & $\begin{array}{l}\text { South } \\
\text { Africa }\end{array}$ & 34 & 432 & Univ. Wisconsin & 16 & 622 & Venables Anthony J. & 7 & 212 \\
\hline 12 & Italy & 32 & 482 & Univ. Amsterdam & 16 & 472 & Le Billon Philippe & 6 & 268 \\
\hline 13 & Switzerland & 31 & 1257 & $\begin{array}{l}\text { Vrije Univ. } \\
\text { Amsterdam }\end{array}$ & 15 & 1240 & Auty Rm & 6 & 208 \\
\hline 14 & Denmark & 30 & 644 & Tilburg Univ. & 14 & 939 & $\begin{array}{c}\text { Nassani } \\
\text { Abdelmohsen A. }\end{array}$ & 6 & 34 \\
\hline 15 & Sweden & 28 & 515 & London Sch Econ & 13 & 417 & Zaman Khalid & 6 & 34 \\
\hline 16 & Turkey & 28 & 198 & $\begin{array}{c}\text { Univ. } \\
\text { Queensland }\end{array}$ & 13 & 128 & Torvik R & 5 & 1330 \\
\hline 17 & Pakistan & 26 & 310 & Leiden Univ. & 13 & 71 & Ross Michael L. & 5 & 546 \\
\hline 18 & Chile & 21 & 311 & Ohio State Univ. & 12 & 214 & Poelhekke Steven & 5 & 350 \\
\hline 19 & Finland & 21 & 216 & $\begin{array}{l}\text { Univ. Calif } \\
\text { Berkeley }\end{array}$ & 12 & 204 & Hilson Gavin & 5 & 102 \\
\hline 20 & Japan & 21 & 205 & Penn State Univ. & 11 & 379 & James Alexander & 5 & 99 \\
\hline
\end{tabular}


Table 3. Cont.

\begin{tabular}{|c|c|c|c|c|c|c|c|c|c|}
\hline Rank & Country & Documents & Citations & Organization & Documents & Citations & Author & Documents & Citations \\
\hline 21 & Brazil & 21 & 142 & Univ. Cambridge & 11 & 234 & Arezki Rabah & 5 & 90 \\
\hline 22 & Malaysia & 20 & 380 & $\begin{array}{l}\text { Colorado Sch } \\
\text { Mines }\end{array}$ & 11 & 209 & Ratner Blake D. & 5 & 89 \\
\hline 23 & Belgium & 19 & 424 & Cesifo & 11 & 71 & Hertog Steffen & 5 & 85 \\
\hline 24 & Colombia & 19 & 136 & $\begin{array}{l}\text { Chr Michelsen } \\
\text { Inst }\end{array}$ & 10 & 843 & Raveh Ohad & 5 & 58 \\
\hline 25 & Russia & 18 & 160 & Stanford Univ. & 10 & 721 & Sarr Mare & 5 & 55 \\
\hline 26 & Iran & 18 & 137 & $\begin{array}{l}\text { Wageningen } \\
\text { Univ. }\end{array}$ & 10 & 555 & $\begin{array}{l}\text { Murshed Syed } \\
\text { Mansoob }\end{array}$ & 5 & 50 \\
\hline 27 & Scotland & 17 & 644 & Monash Univ. & 10 & 271 & Ovadia Jesse Salah & 5 & 38 \\
\hline 28 & India & 17 & 289 & Univ. Alberta & 10 & 123 & Tiba Sofien & 5 & 38 \\
\hline 29 & $\begin{array}{l}\text { Saudi } \\
\text { Arabia }\end{array}$ & 17 & 135 & $\begin{array}{c}\text { Univ. } \\
\text { Copenhagen }\end{array}$ & 10 & 84 & Davis Graham A. & 5 & 31 \\
\hline 30 & $\begin{array}{c}\text { New } \\
\text { Zealand }\end{array}$ & 16 & 368 & & & & & & \\
\hline
\end{tabular}
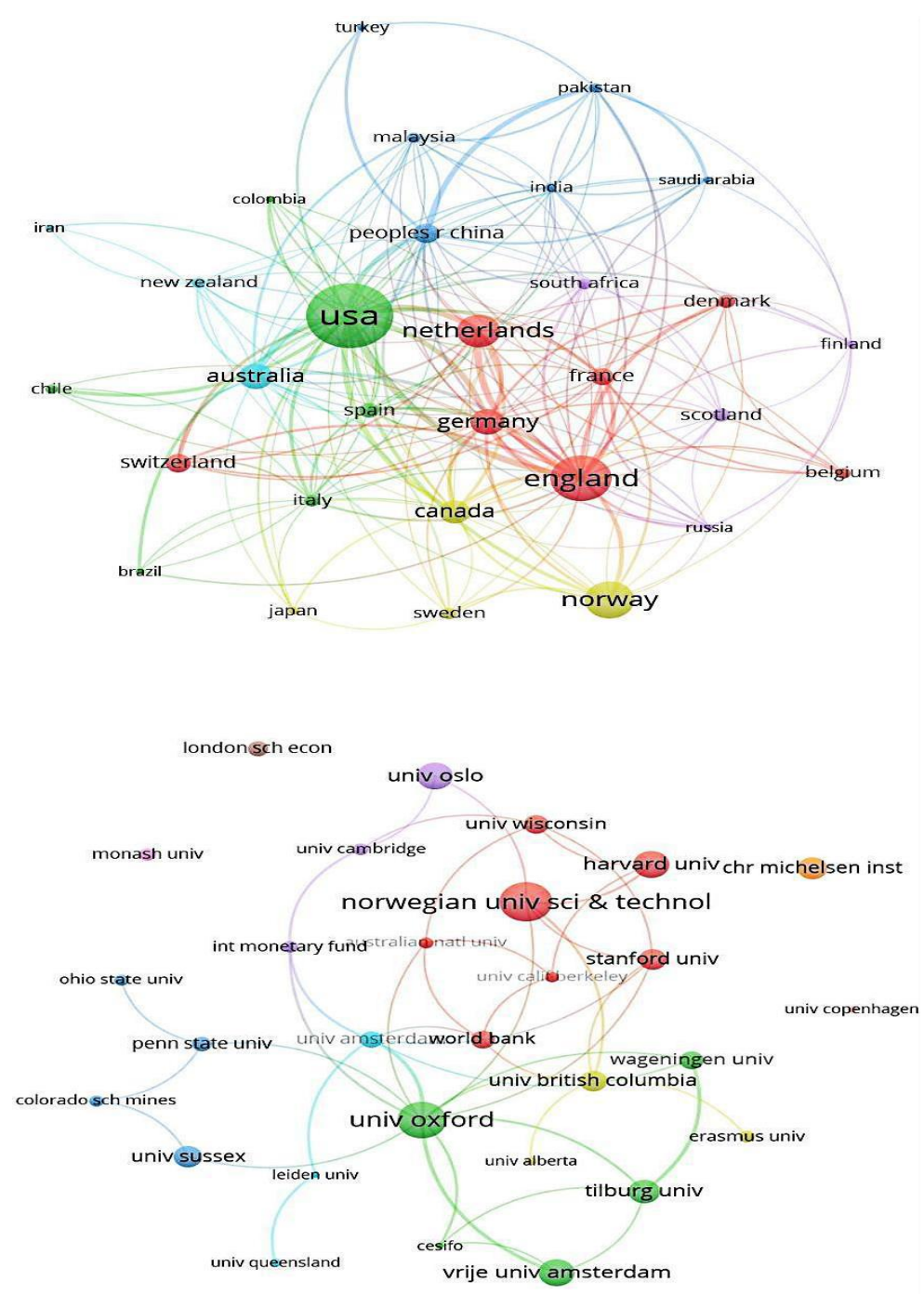

Figure 9. Cont. 


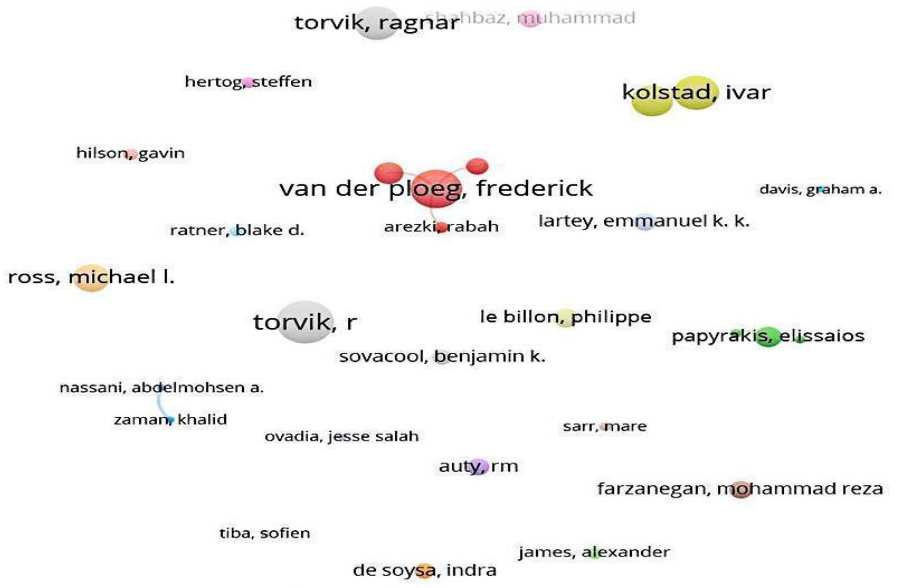

Figure 9. Comparison of the publication number by top30 countries, top 29 institutions, and top 29 authors (using VOSviewer).

\subsection{Productive Researchers}

The author utilized VOSviewer to learn how authors interact in "Resource Curse, Dutch Disease, and Conflict resource" research. The "minimal number of "author document" was set to 5. As seen in Figure 10, just 29 of the total 3093 authors reached the threshold and could be added to the ultimate structure. We can recognize that American scientist Benjamin K. Sovacool, Norwegian scholar Rangan Gupta, and British scholar Rick van der Ploeg have published 10 articles, ranking them first in terms of the document number. Furthermore, Ragnar Torvik had the highest citation record (1327), while Rick van der Ploeg was the second most cited scholar (1054), followed by Ivar Kolstad (819). Ragnar Torvik teaches economics (NTNU) at the Norwegian University of Science and Technology; He has worked in many public societies, including the Capital Flight Committee and the Climate Risk Committee. Rick van der Ploeg is another prominent researcher who is an economics professor at the Vrije Universiteit Amsterdam. His core research priorities are macroeconomics and public finance, applying natural resource economics and climate change applications. Ivar Kolstad is an Associate Professor of Business Ethics. His latest studies have been related to corporate social responsibility and political economics. One of his findings showed that broad markets and countries with a mix of vast natural resources and weak systems attract Chinese outward FDI [73].

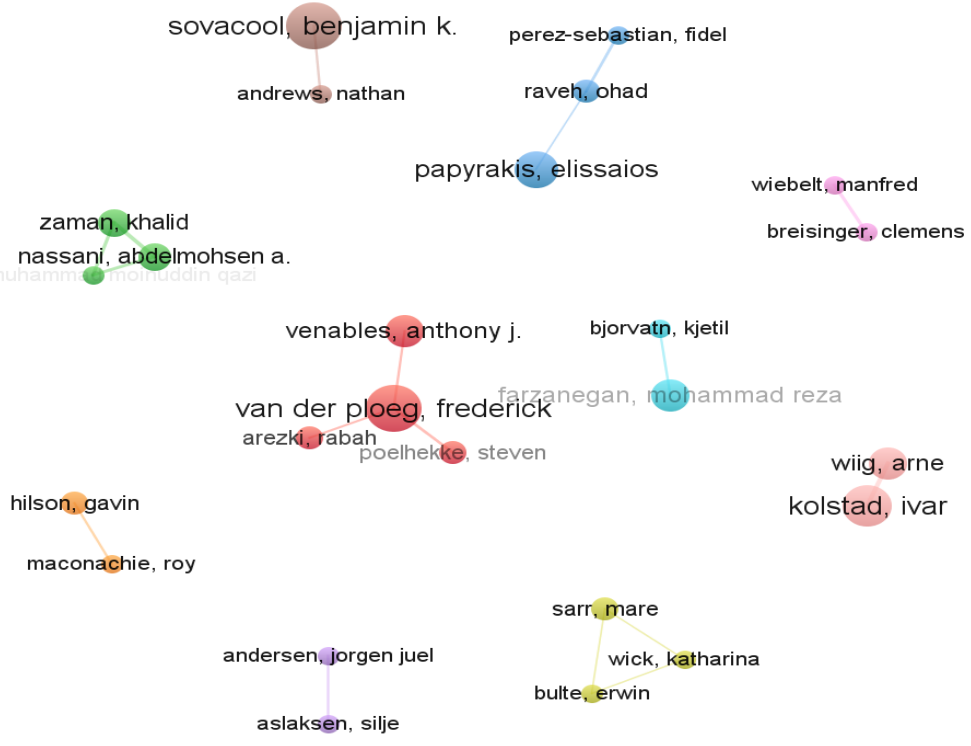

Figure 10. The scholars' co-authorship. 
CiteSpace was used to examine the top $50 \%$ of references with the most citations each year from 1993 to 2020; the author noticed three scholars with occurrence explorations, as seen in Figure 11. RM Auty was again found, who coined the term "Resource Curse" in 1993. Furthermore, Ivar Kolstad, Aren Wiig, and Frederick van der Ploeg were identified; all of their citation explorations occurred in 2009.

\begin{tabular}{|c|c|c|c|c|c|c|}
\hline Authors & Year & Strength & Begin & End & Lasting time (1993-2020) & Yearly Duration \\
\hline RM AUTY & 1993 & 3.97 & 1994 & 2001 & & 7 \\
\hline IVAR KOLSTAD & 1993 & 4.94 & 2009 & 2012 & & 3 \\
\hline ARNE WIIG & 1993 & 3.84 & 2009 & 2012 & & 3 \\
\hline FREDERICK VAN DER PLOEG & 1993 & 3.55 & 2009 & 2013 & & 4 \\
\hline
\end{tabular}

Figure 11. Authors with occurrence explorations during 1993-2020.

\section{Co-Occurrence Analysis of Intellectual Foundations \\ 5.1. Discipline Co-Occurrence Analysis}

Figure 12 depicts a CiteSpace display with annotations. It compares and contrasts the citing and cited map data. On the left is shown its referencing network diagram, which includes 10,330 referring journals. On the right is shown its referenced graph, which includes 10,253 cited journals. Each dot represents a journal, and its color indicates whether it belongs to the Blondel Cluster. There are many choices available, including shifting from Blondel and VOSviewer groups, changing the time unit from annual to monthly (YRMTH and MTHYR), and calculating tracks at the group or journals stage (CJ and JC). The reference linking form is controlled by the linking style in the top right corner. Citespace's overall setup includes two kinds of styles: curves and arcs. A referral link is shown as a parabolic arc in the arc style. The arc style represents a quotation connection as a spline curve that runs from the original journal to the citation's destination journal. The arc style is intended to clarify the display of a significant number of reference links clearer.

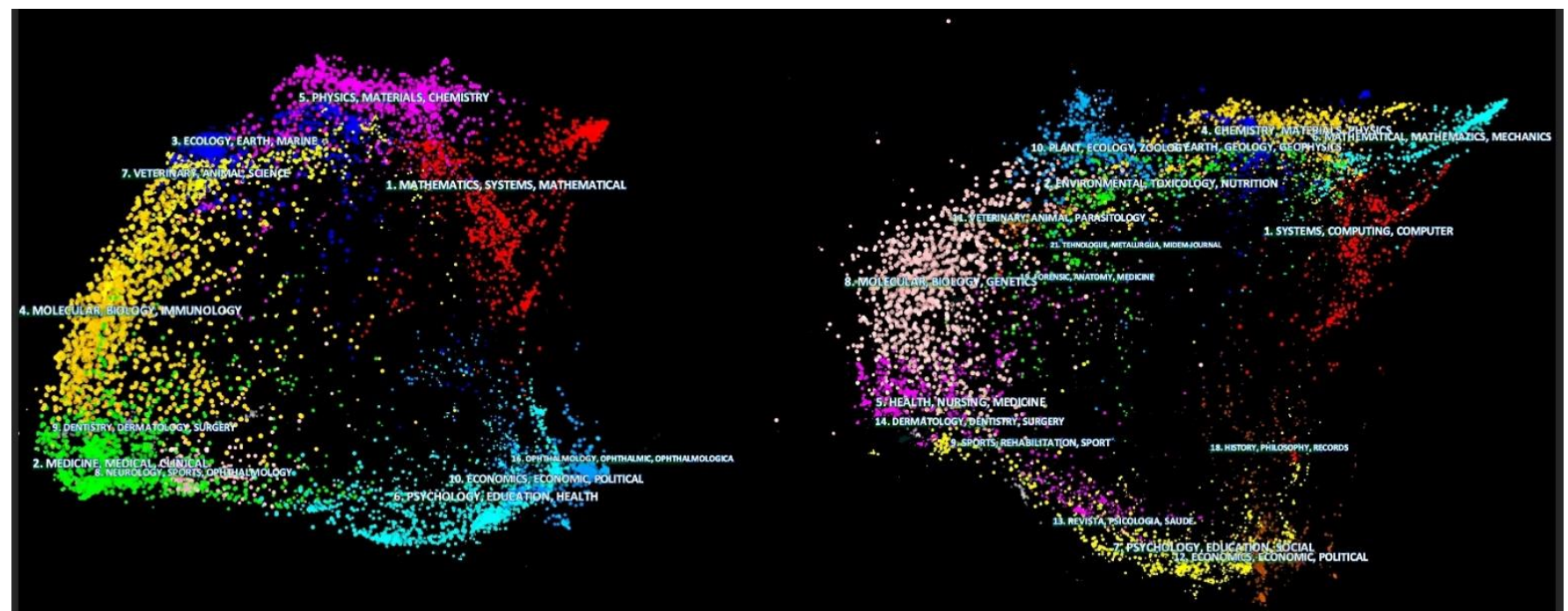

Figure 12. The Citespace interface as it first appeared, with citing and cited journal base maps shown concurrently. On the left is a base map with 10,330 citing journals. On the right is a base map with 10,253 referenced journals. Blondel's clustering method identified the groupings in various colors [74].

In this Resource Curses, Dutch Diseases, and Conflict Resources research domain, dual-map overlay evaluations allowed tracing the conceptual basis of exceptionally fruitful and frequently cited articles. Figure 13 depicts the results. 
its

$\therefore$ in 0

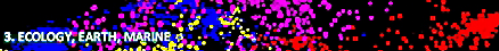

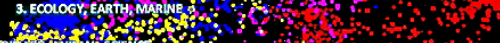

7 . vane

fis $1+0$

s.

$2 x$

$x^{4}+x^{2}$

$20 \%$

thentis.

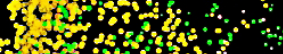

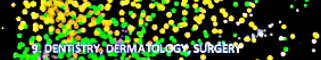

2.m. of

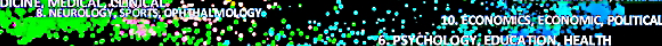
Now

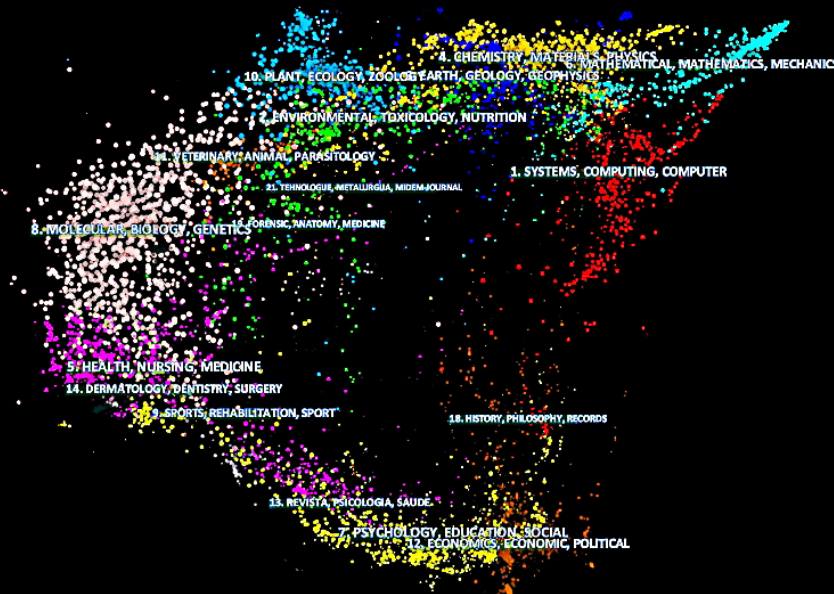

H.

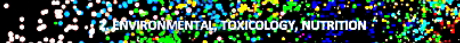

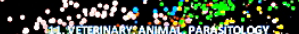

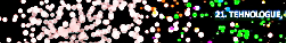
$\therefore$ or

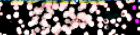

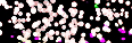

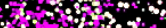

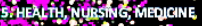

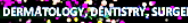

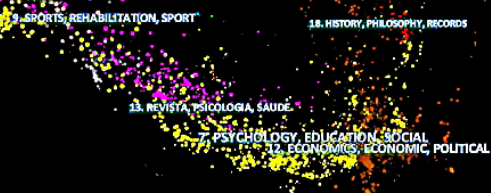
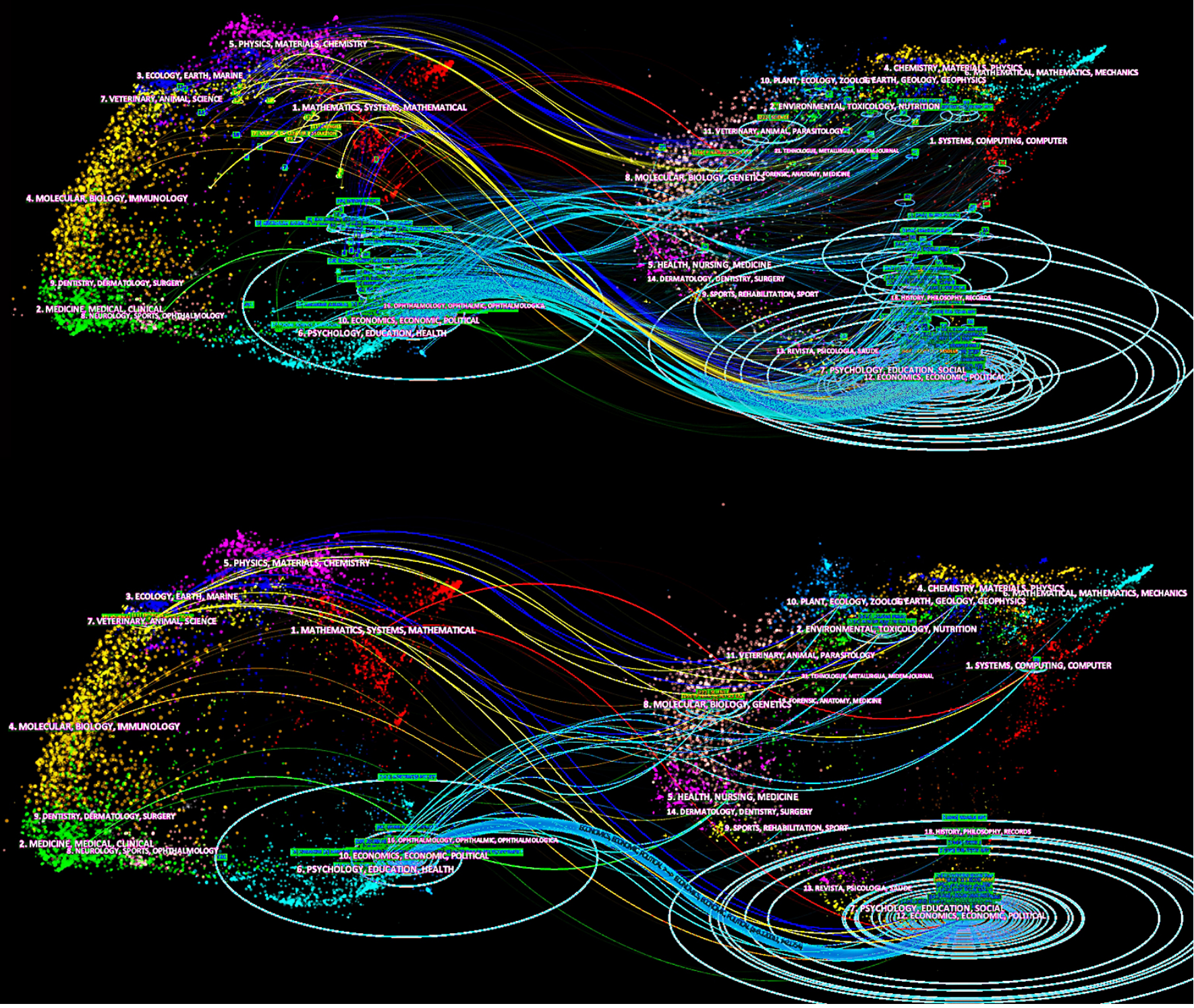

Figure 13. The journal-based dual-map of the Resource Curses, Dutch Diseases, and Conflict Resources-related papers on the global scientific mapping. 
The viewing of dual-map overlays was conducted using CiteSpace [75]. At the same time, Carley and his collaborators developed a journal-based dual-map overlay [76]. It allowed displaying the publications in a particular data collection on the journal map of the global research domains. This review then followed the articles in those journals reference lists, overlaid them on another journal overlay graph, and connected the two graphs. Labeled ovals signify clusters of periodicals commonly referenced and cited. The intensity of the lines refers to the total citations received from the Resource Curses, Dutch Diseases, and Conflict Resources-related publications on the left and articles of the citing papers from the right.

Consequently, the global science map in Figure 13 upper left represents the circulation of the Resource Curses, Dutch Diseases, and Conflict Resources publications; the distribution of referenced articles can be seen on the right edge. Figure 13 (medium and bottom) section simplifies more details by focusing on referenced article clusters. This was done by modifying the thickness of the lines according to the density of citations, using the z-record of citation connections [77]. Figure 13 reveals that Resource Curses, Dutch Diseases, and Conflict Resources-related publications are primarily distributed in the "Economy, Economic, and Political" groups of journals. The cited articles, which can be thought of as the intellectual base of the scientific domain, are mainly contained in the journal group "Economy, Economic, and Political." Figure 13 (lower half) depicts the major journal classes and their relationships, with the z-score used to scale the line thicknesses.

It can be illustrated that all the referring groups have cited articles from the "Economics, Economic, and Political" or "Psychology, Education, and Health" journal areas. This means that the academic foundation of the Resource Curses, Dutch Diseases, and Conflict Resources-related science remains relatively narrowly centred across particular scientific subdomains. The tendency for articles to cite publications from their publishing category is common.

\subsection{Mainstream Journals}

A process was established to review current journals. The author utilized VOSviewer to identify publications and reference journals on "Resource Curse, Dutch Disease, and Conflict resource." The "minimum number of source references" was adjusted to 8 to make the network more transparent. As a result, only journals with over eight documents are displayed. Forty journals reach the threshold out of 556 journals found. The nodes in Figure 14 reflect the number of publications by each journal. The intensity of the relationship between the nodes reflects the node's scale, representing the number of related articles written by scholars and the number of citations between references in the two journals. Resources Policy, World Development, Journal of African Economies, Journal of Development Economics, and Energy Economics were the top 5 journals. Forty journals were divided into three clusters, each with its collection of subjects and colors. Journals in the red Cluster, for example, are concerned with comparative political studies; those in the green Cluster are concerned with resources policy or African political economy; those in the sky-blue Cluster are concerned with energy policy or economic systems.

Figure 15 shows the top 5 journals' annual occurrence growth. The loess smoothing method was utilized. The smooth line was produced using locally weighted smoothing and regression analysis because loess smoothing promotes the comprehension of treads over time [78]. After 2011, the number of publications by Resources Policy, which is the primary source of Resource Curses/Dutch Diseases literature in Social Science, has increased significantly. From 2007 to 2011, there is a downward trend in the number of publications from Extractive Industries and Society-An International Journal. However, from 2013 onward, a sharp rise could be found in the number of publications. 


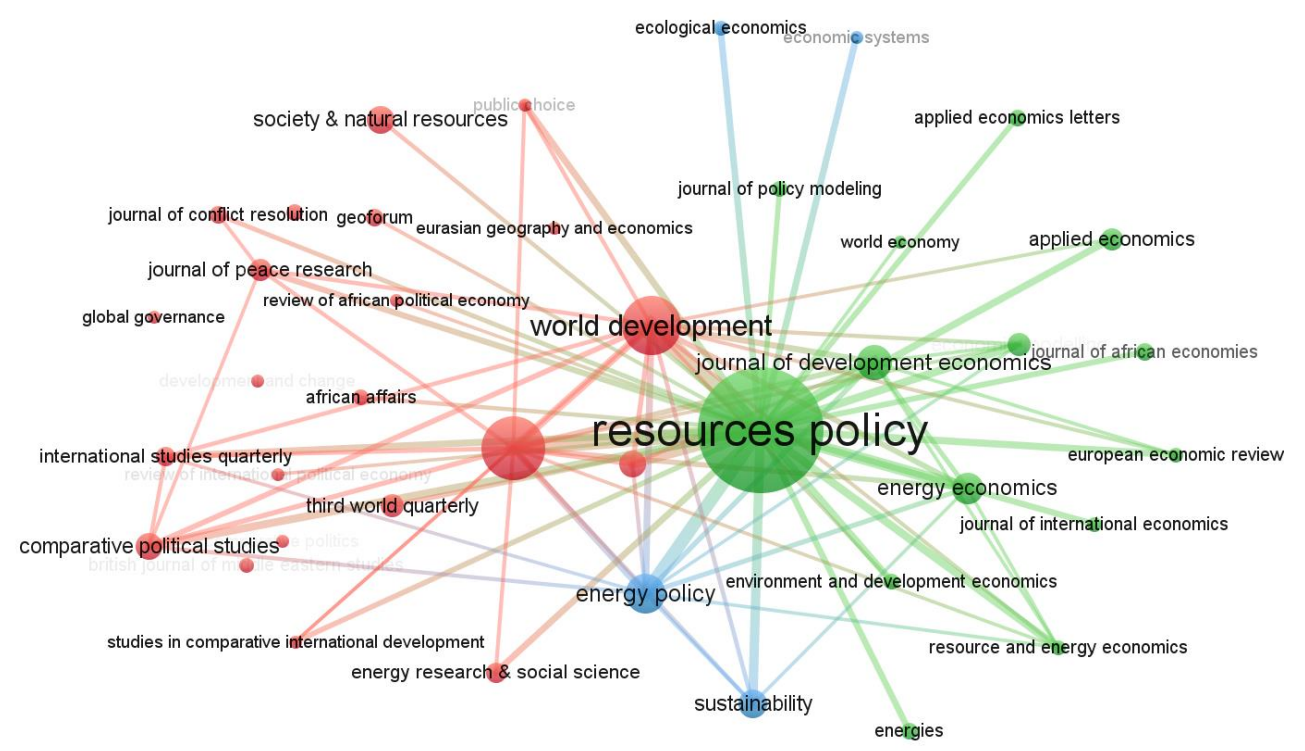

Figure 14. The consortium of eminent journals.

\section{Source Growth}

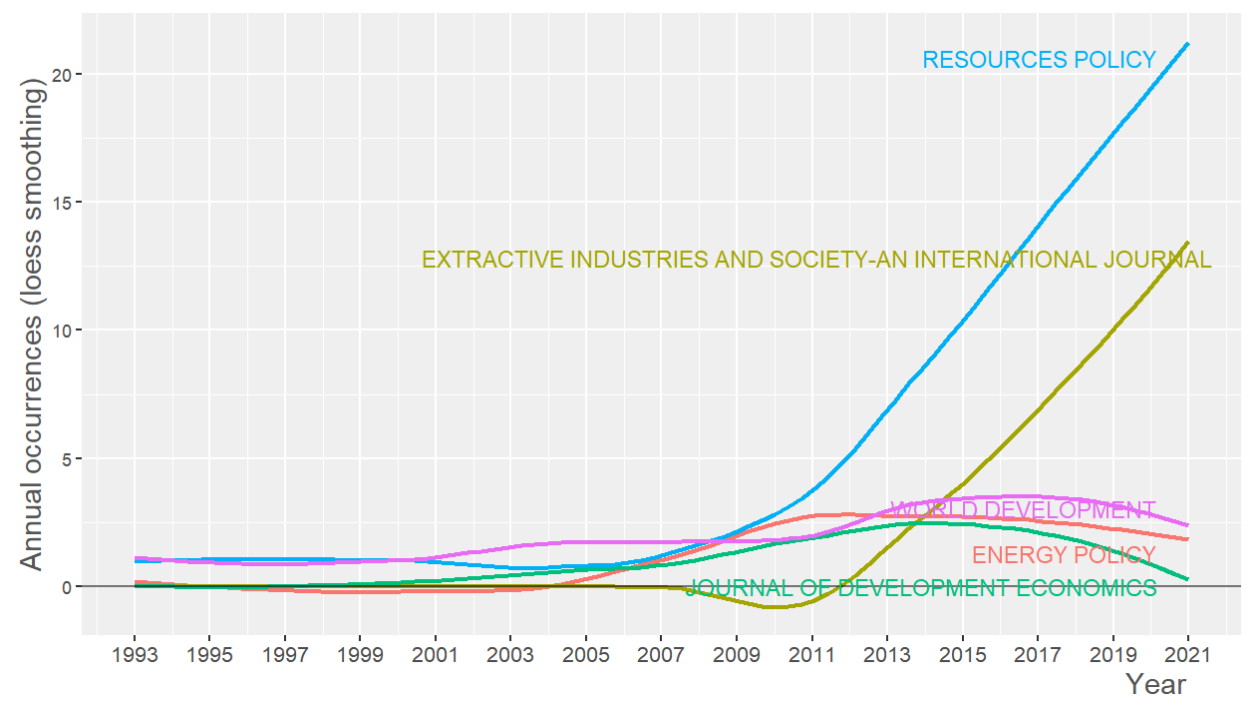

Figure 15. Annual occurrence growth of the top five journals.

Although, as shown in Figure 15, the annual occurrences of the journal World Development have slightly decreased since 2013, the Impact Factor of this journal increased by 2.225 in the last 5 years to 5.278, which denotes that the journal is thriving and energetic [79].

Scholars and managers can review these journals during pandemics since they may have valuable intelligence about the socioeconomic effects. When regressing over time, most of the journals have no noticeable loess smoothing. As can be referred from the VOSviewer Manual [80], There are two standard weight attributes: the Connection attribute and the Total Connection Strength attribute. For a given item, the Connection and Total Connection Strength attributes indicate, respectively, the number of Connections of an item with other items and the total strength of the Connections of an item with other items. For example, in co-authorship connections between researchers, the Connections attribute indicates the number of co-authorship Connections of a given researcher with other researchers. The Total Connections strength attribute indicates the total strength of the co-authorship Connections of a given researcher with other researchers [80]".

To obtain a precise visualization with VOSviewer, it is essential to set a threshold. However, without a threshold, we can access all the journals' elements. Table 4 lists the 
leading 15 journals that were accompanied by the most significant document records and the highest average connection strengths in this field. Resources Policy had the largest (161) document number and most significant total connection strength (1288). For each of the three strings of literature, the author conducted a separate journal direct citation review. The author identified 35, 28, and 11 journals for the Resource Curses, Dutch Diseases, and Conflict Resources literature when limiting the "minimal total of documents of a journal" to 5, as seen in Figures A1-A3 (Appendix A). Most mainstream journals do not appear to favor any of the three strings of literature. Papers on the Resource Curses also appeared in various journals, including African Studies, comparative politics, political economy, ecological economics, conflict studies, and administrative management. Most Dutch Disease journals were related to applied economics, geo-economics, and African economics. The Conflict resource literature includes three journals primarily concerned with ecological sociology and human ecology.

Table 4. Top 15 journals in terms of document number and total connection strength.

\begin{tabular}{|c|c|c|c|c|}
\hline Rank & Journals & Records & Journals & TCS \\
\hline 1 & Resources Policy & 161 & Resources Policy & 1288 \\
\hline 2 & $\begin{array}{c}\text { Extractive Industries and } \\
\text { Society-an International Journal }\end{array}$ & 65 & World Development & 778 \\
\hline 3 & World Development & 58 & $\begin{array}{c}\text { Journal of Development } \\
\text { Economics }\end{array}$ & 506 \\
\hline 4 & Energy Policy & 34 & $\begin{array}{c}\text { Extractive Industries and } \\
\text { Society-an International Journal }\end{array}$ & 402 \\
\hline 5 & $\begin{array}{c}\text { Journal of Development } \\
\text { Economics }\end{array}$ & 29 & Economic Journal & 322 \\
\hline 6 & Energy Economics & 25 & European Economic Review & 298 \\
\hline 7 & Sustainability & 22 & Energy Policy & 287 \\
\hline 8 & Society \& Natural Resources & 21 & Comparative Political Studies & 241 \\
\hline 9 & Comparative Political Studies & 20 & $\begin{array}{l}\text { Journal of Environmental } \\
\text { Economics and Management }\end{array}$ & 200 \\
\hline 10 & Journal of Development Studies & 20 & Journal of Development Studies & 192 \\
\hline 11 & Economic Modelling & 17 & Energy Economics & 189 \\
\hline 12 & Third World Quarterly & 17 & Journal of Conflict Resolution & 181 \\
\hline 13 & Applied Economics & 16 & Journal of Peace Research & 144 \\
\hline 14 & Journal of Peace Research & 16 & $\begin{array}{l}\text { Resource and Energy } \\
\text { Economics }\end{array}$ & 130 \\
\hline 15 & $\begin{array}{l}\text { Energy Research \& Social } \\
\text { Science }\end{array}$ & 14 & $\begin{array}{c}\text { Scandinavian Journal of } \\
\text { Economics }\end{array}$ & 126 \\
\hline
\end{tabular}

TCS = total connection strength.

As shown in Table A1 (Appendix A), there was an overlap across the three strings of mainstream journals. For example, the Resource Curses and Dutch Diseases literature clearly overlapped in terms of energy economics, energy politics, and development economics. Four journals, including three journals on comparative political economy, development politics, resource sociology, and sustainable development, have published over 20 articles on these three academic sub-domains.

\subsection{Keyword Frequency Analysis}

VOSviewer was used to produces the keyword co-occurrence matrix map, as well as a keyword intensity map (Figure 16). Links represent the correlation degree between two keywords, whereby a thicker link denotes a stronger correlation. The workflow of Figure 16 can be seen in Figure 17. 


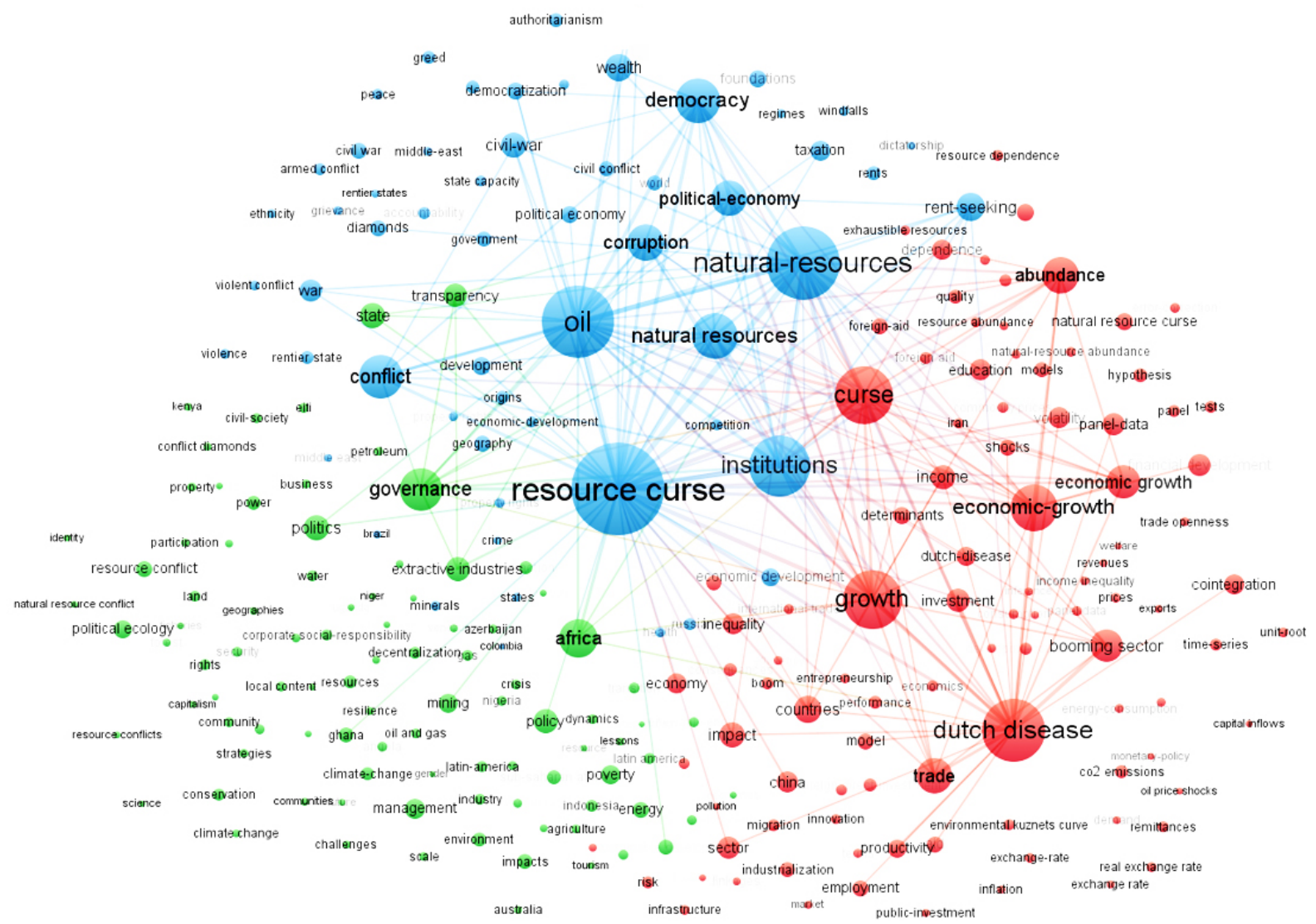

Figure 16. The keyword co-occurrence frequency colorful map (using VOSviewer).

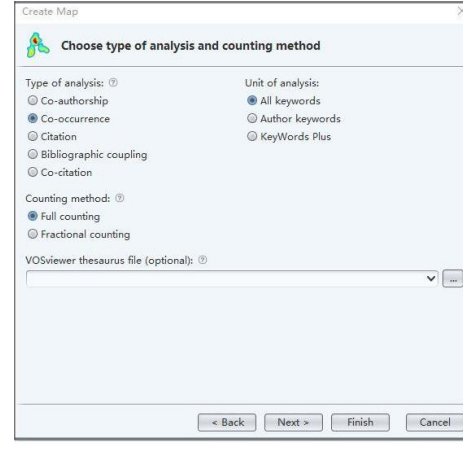

(1) Co-occurrence tpye and all keywords Unit analys

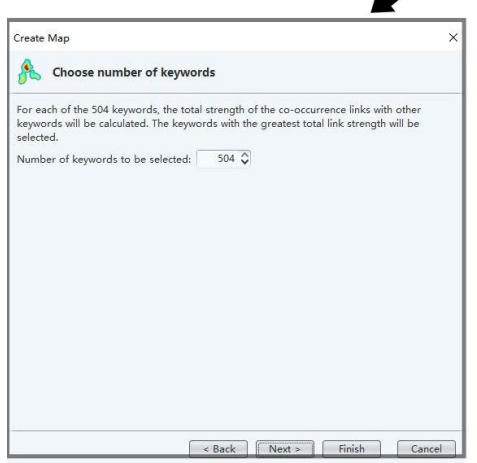

(3) Number of keyword to be selected

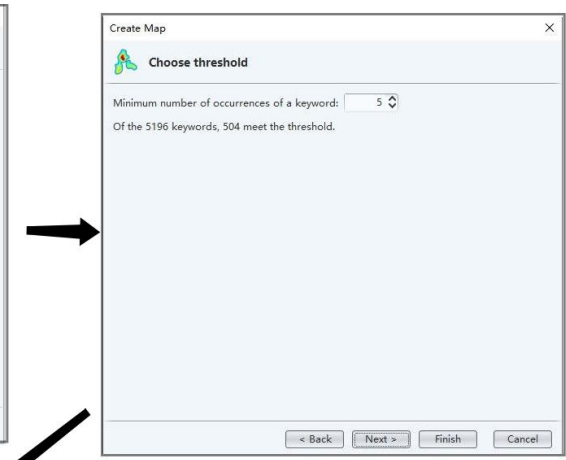

(2) Minimum number of occurrences of a keyword seting

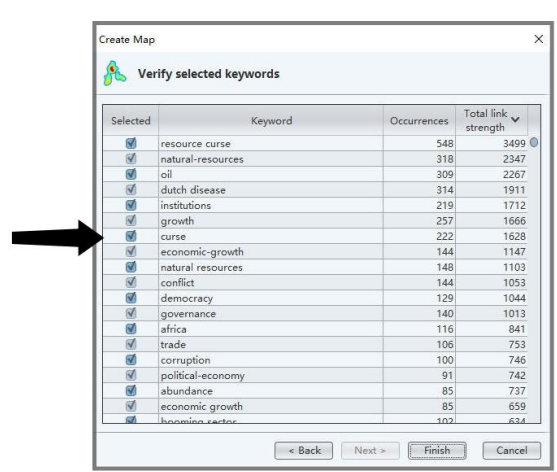

(4) Verify selected keywords

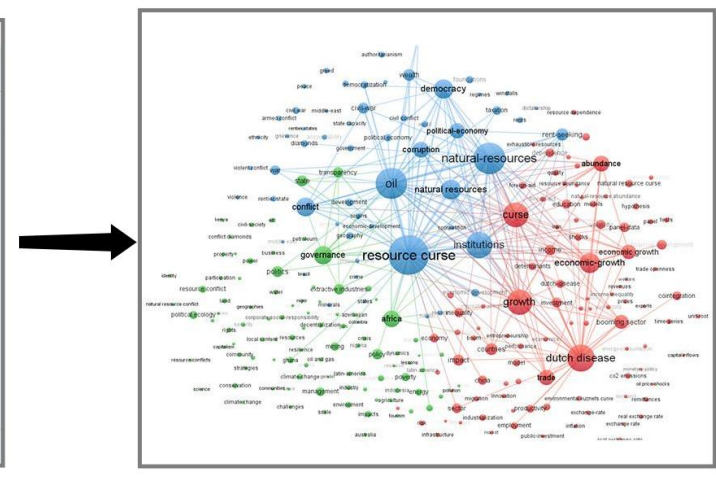

(5) Network Visualization

Figure 17. Integrated research mapping workflow of keyword network (using VOSviewer). 
Keywords in this field represent hotspots and scientific innovations [81]. The author found 5196 keywords that appeared only once, 504 keywords with a level of occurrence of 5, and 254 keywords with a frequency above10. Table 5 shows the top 20 keywords by co-occurrence frequency and total connection strength, where the level of co-occurrence is reflected by the connection strength [82].

Table 5. The top 20 keywords used in Figure 16.

\begin{tabular}{cccccc}
\hline Keyword & Occurrences & TCS & Keyword & Occurrences & TCS \\
\hline Resource Curse & 548 & 2986 & Governance & 140 & 846 \\
Natural-Resources & 318 & 2072 & Democracy & 129 & 924 \\
Dutch Disease & 314 & 1612 & Africa & 116 & 733 \\
Oil & 309 & 1997 & Trade & 106 & 647 \\
Growth & 257 & 1456 & Booming Sector & 102 & 538 \\
Curse & 222 & 1418 & Corruption & 100 & 675 \\
Institutions & 219 & 1520 & Political-Economy & 91 & 650 \\
Natural Resources & 148 & 969 & Abundance & 85 & 659 \\
Conflict & 144 & 896 & Economic Growth & 85 & 576 \\
Economic-Growth & 144 & 1002 & Politics & 80 & 377 \\
\hline
\end{tabular}

TCS = total connection strength.

The top five most frequently occurring keywords were "Resource Curse", "natural resources", "Dutch Disease", "oil", and "growth", as presented by the five most prominent nodes. Each keyword was divided into four clusters with its brightness. "Resource Curse", "natural -resources", "institutions", "corruption", "democracy", and "rent-seeking" belonged to the blue Cluster, reflecting the "Resource Curse" literature, which was the largest Cluster and typically linked with political economy, corruption, and democracy. Keywords in the green cluster were "Africa", "poverty", "Nigeria", "Ghana", "Congo", "local content", "conflict diamonds", and "Niger." The green Cluster was the second largest, reflecting African-related hotspots. The most relevant keywords were related conflict minerals and blood diamonds, as well as the influence of foreign companies on resource-rich countries such as DR Congo and Ghana. The red Cluster represented "Dutch Disease" literature and contained 60 keywords, such as "Dutch Disease", "economic growth", and "industrialization." It mainly concerned resource economics, development economics, and comparative politics, as well as problems relating to Dutch Disease, such as "foreign aid", "education", "income", "investment", and "economic growth".

The intensity of a specific node in the keyword density mapping chart is determined by the number of networks the node has. The neighboring nodes surrounding another node will be recognized. According to keyword intensity, the keyword "oil" was closely correlated with the blue and green clusters and the red Cluster, meaning that the blue Cluster benefits from the red Cluster research (economic growth). The green cluster analysis was also strongly correlated.

The three clusters in Figure 16 represent the hotspots of the three strings of literature, and their features match what the author detected in Sec 5.2. There were several critical distinctions among the three most essential clusters: While the Dutch Disease literature frequently utilizes panel data and favors developed countries, namely, the Netherlands, Norway, and Sweden in northern Europe, the African-related literature, unlike the Dutch Disease literature frequently utilizes case studies and pays equal attention to the least industrialized nations such as the sub-Saharan Africa countries.

CiteSpace is excellent at identifying hot trends in a research field by searching for keywords with high-frequency explorations. The author found 44 keywords of frequency explorations, showing the sudden increase in their occurrence frequency. The author focused on the top $40 \%$ of references with comparatively higher citations per year from 1993 to 2020.

The top 25 keywords with the most robust occurrence explorations are reported in Figure 18. Many of them can also be found in Figure 18, for example, "booming sector", 
"Dutch Disease", "political ecology", "economy", "natural resource", and even "rentseeking". The keyword "Oil" was ranked first with a scores of 14.31, and the keyword "Indonesia" had a 16-years long exploration (from 1993 to 2009). These keywords were prevalent in not only one string of the literature, which provoked their citation explorations. Compared to the other two strings of literature, the Resource Curse literature had a more significant number of keywords because of citation explorations. Between 1993 and 2017, the Resource Curse literature had the most yearly publications among the three strings of literature. "Authoritarianism", "civil war", and "democratization" were all keywords from the Resource Curse literature, as well as "development", "extraction", and "Ghana". Four keywords of continuing occurrence explorations until 2020 were "Participation", "Ghana", "oil and gas", and "exchange rate". Table A2 (Appendix A) shows keywords purely from one string of the literature. "Ghana" was related to Resource Curse analysis, and "exchange rate" related to Dutch Disease research.

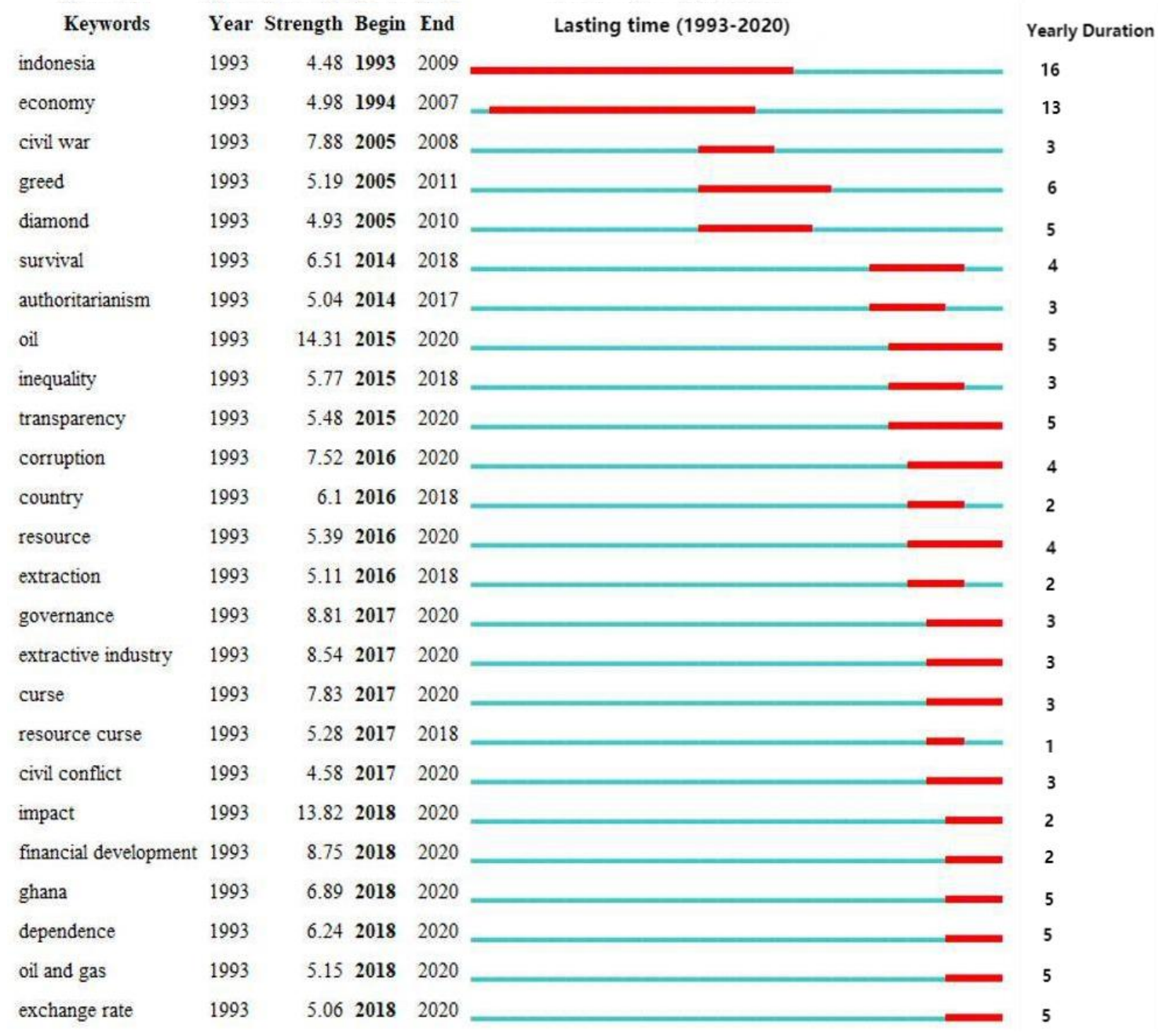

Figure 18. Top 25 keywords with the most robust occurrence explorations.

\subsection{Reference Co-Citation Analysis}

5.4.1. The Most Prominent Clusters with Co-Citations

Citespace was used again to provide a timeline view structure of co-citations to examine the primary literature in the evolution point to reflect each Cluster's development trajectory and status quo (Figure 19). The author chose the g-index as the selection criterion (scale factor $\mathrm{k}=25$ ). No pruning method was used to gain more information on the clusters. 


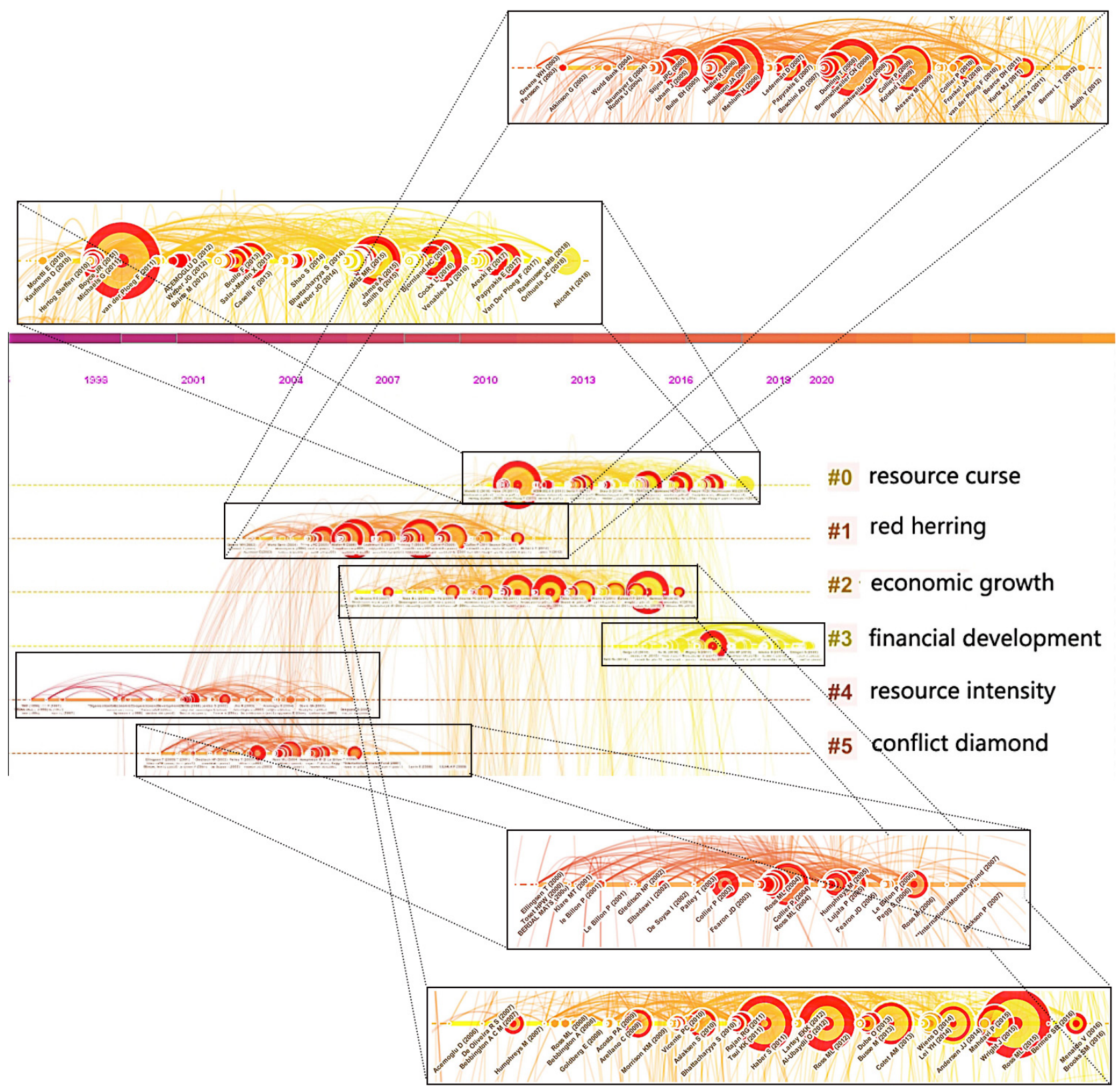

Figure 19. A timeline image of the reference co-citation framework from 1993-2020.

According to the publication time, from left to right, all clusters could be identified. Three node styles are of special attention, i.e., large nodes display references strongly cited, tree rings nodes indicate critical experiments of citation explosions, and purple tree rings nodes have robust core considerations.

Because of the length limitations of this research, the author focused on Clusters 0-2, which were the top three major clusters as well as another highly involved Cluster (Cluster 5). The Carrot2 tool was utilized to explore them further.

Cluster 0: Resource curse

As shown in Figures 20 and 21 and Table 6, the largest Cluster was Cluster 0, containing 154 references with an average publishing year of 2014. The silhouette value of Cluster 0 was 0.868 , illustrating that Cluster 0 was very consistent. Given that it was the most fantastic Cluster, its themes were relatively diffuse. Carrot 2 can process critical concepts extracted from cited articles' titles, keywords, and abstracts using an algorithm method [83]. Cluster 0's fundamental principles denote important landmarks concerning oil production, developing states, and political institutions, as seen in the foam tree visu- 
alization (Figure 15). Concepts such as oil prices, income inequality, commodity prices, fiscal policy, and local mining highlight this session's primary focus. The frequency with which key references are cited can show these studies' relative relevance and contributions to Resource Curse research. As a result, recognizing these significant efforts will benefit future researchers in grasping critical research of the Resource Curses/Dutch Diseases [84]. The first period was from 2011 to 2014, and the second period was from 2015 to 2017.

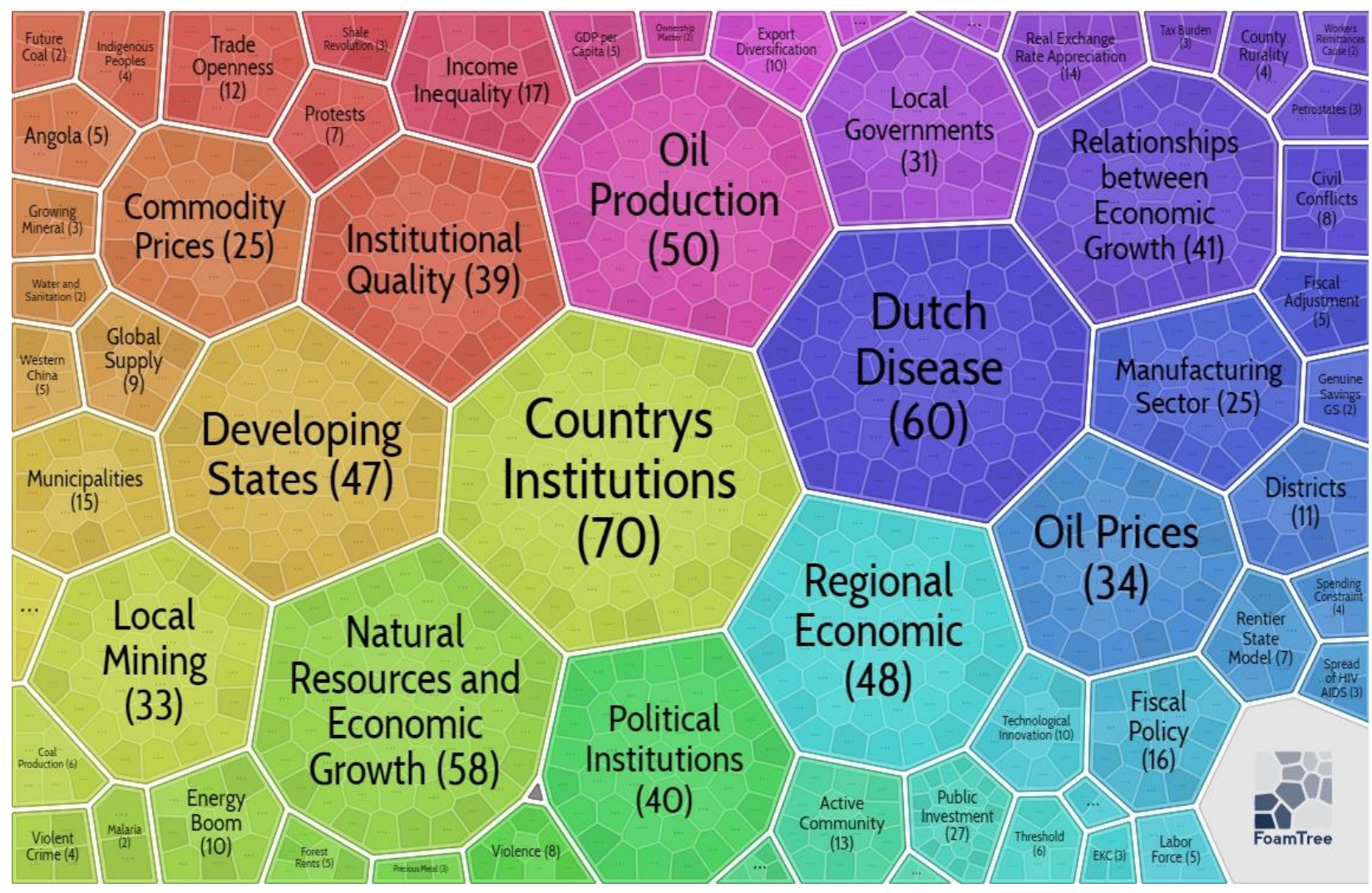

Figure 20. Keywords in Cluster 0 (using Carrot2 4.3.1).

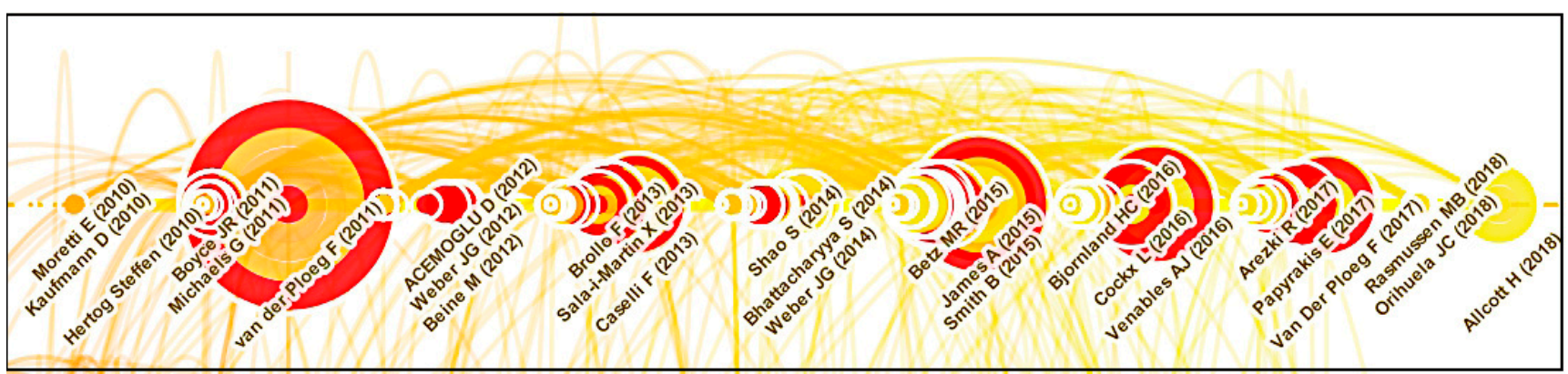

Figure 21. A timeline visualization of the Cluster 0 co-citation network (using Citespace 5.7.R4). 
Table 6. Exploration and summary of Cluster 0.

\begin{tabular}{|c|c|c|c|c|c|}
\hline Freq & Burst & Author & Year & Source & HalfLife \\
\hline 81 & 36.42 & van derPloeg F & 2011 & Journal of Economic Literature & 3.5 \\
\hline 10 & 5.84 & Williams A & 2011 & World Development & 4.5 \\
\hline 12 & 5.82 & Boyce JR & 2011 & Resources Policy & 3.5 \\
\hline 12 & 5.82 & Michaels G & 2011 & The Economic Journal & 3.5 \\
\hline 12 & 6.47 & Beine $\mathrm{M}$ & 2012 & Resource and Energy Economics & 3.5 \\
\hline 11 & 6.1 & Weber JG & 2012 & Energy Economics & 3.5 \\
\hline 10 & 5.55 & Bjorvatn $\mathrm{K}$ & 2012 & World Development & 4.5 \\
\hline 26 & 11.84 & Caselli F & 2013 & $\begin{array}{c}\text { American Economic Journal: Applied } \\
\text { Economics }\end{array}$ & 2.5 \\
\hline 18 & 8.96 & Boschini A & 2013 & World Development & 3.5 \\
\hline 19 & 8.66 & Sala-i-Martin X & 2013 & Journal of African Economies & 3.5 \\
\hline 16 & 7.27 & Aragon FM & 2013 & $\begin{array}{l}\text { American Economic Journal: Economic } \\
\text { Policy }\end{array}$ & 3.5 \\
\hline 12 & 5.741 & Bhattacharyya S & 2014 & World Development & 3.5 \\
\hline 10 & 5.51 & Shao S & 2014 & Energy Policy & 4.5 \\
\hline 13 & 5.34 & Weber JG & 2014 & Resource and Energy Economics & 2.5 \\
\hline 30 & 7.79 & Smith B & 2015 & Journal of Development Economics & 3.5 \\
\hline 29 & 6.82 & James A & 2015 & Journal of Development Economics & 3.5 \\
\hline 13 & 4.87 & Fleming DA & 2015 & $\begin{array}{c}\text { Australian Journal of Agricultural and } \\
\text { Resource Economics }\end{array}$ & 3.5 \\
\hline 28 & 8.48 & Venables AJ & 2016 & Journal of Economic Perspectives & 2.5 \\
\hline
\end{tabular}

More specifically, during the first period from 2011 to 2014, van der Ploeg (2011) represented the first citation exploration. Van der Ploeg (2011) [5] looked into several hypotheses and supporting facts to see why certain countries benefit from mineral wealth while others lose out. In addition, he suggested several welfare-based fiscal principles for capturing resource windfalls in both rich and developing economies.

Among the most prominent policy proposals for resolving the so-called "Resource Curse", Williams (2011) [85] proposed a robust negative causal relationship between accessibility and (point) resource export profits. He revealed that a lack of openness is linked to a subsequent drop in growth in the economy.

Cross-sectional development regressions show that societies reliant on natural resource exports have grown more slowly than societies with limited natural resources. In the lack of market and institutional flaws, Boyce and Emery (2011) [86] proved that the relationship between development and natural resource availability could be adverse. Oil-rich counties experienced more substantial birth rates, higher per capita incomes, and superior infrastructure, according to Michaels (2011) [87].

Beine et al. (2012) [88] argued that failing to separate the expansion of the Canadian dollar from the growth of the US dollar contributes to possibly inaccurate conclusions about the Dutch Diseases instance in Canada. Weber (2012) [89] discovered that a boost in the value of natural gas led to small gains in labor, wage and salary earnings, and median family income. In order to comprehend the "Resource Curse", Bjorvatn et al. (2012) [90] looked into the function of political socioeconomic disparities. The political power imbalance, they discovered, progresses the economic profit of resource rents. Resource riches can encourage investment even in the absence of well-developed institutions when accompanied by a strong administration, whereas adding oil wealth to a dysfunctional government might have negative consequences for the economy. Caselli and Michaels (2013) [91] discovered that cities with a lot of oil have more incomes and spend more on public services. Boschini et al. (2013) [92] believed that, if the institutional quality was good enough, the negative relationship between mineral resource concentration and economic development could be overcome.

Sala-i-Martin and Subramanian (2013) [93] discovered that, in Nigeria's case, oilrelated waste and inadequate institutional quality seem to be the reason for the country's low long-term economic growth. They also presented a method to mitigate the 
Resource Curse by distributing oil earnings aimed at the general populace. Aragón and Rud (2013) [94] looked into the influence of Yanacocha, an extensive gold mining area in Northeastern Peru. They discovered evidence of a beneficial impact on actual income from mining demand for local goods. The consequences are only noticeable throughout the supply chain and its environs. Bhattacharyya and Hodler (2014) [95] showed that if political systems were poor, natural resource income degraded contractual compliance. Resource revenues impeded economic advancement in nations with weak government systems because poor contract enforcement resulted in lower economic literacy.

Relying on an organic mixture of theoretical and statistical models, Shao and Yang (2014) [96] conducted an exploratory study to clarify the co-existence of the both the Resource Curse with resource blessing realities. The efficiency with which capital assets are allocated determines whether the blessing happens. Enough human capital is a necessary condition for avoiding the curse. However, several studies have shown that regions that are more reliant on mineral wealth grow slowly. Weber (2014) [97] discovered minimal evidence of a growing curse from increased natural gas production throughout the 2000s. Variations in the adult population by level of education show that higher productivity does not imply a lower degree of education.

More peculiarly, during the second period from 2015 to 2017, James (2015) represented the first citation exploration. James (2015) [98] proposed an alternate theory for the Resource Curse: a resource domain that was slow to grow. A diminishing mining sector disproportionately impacts resource-dependent countries. In cross-country growth regressions, he also showed the necessity of taking industry mix into account. Fleming et al. (2015) [99] believed that resources were a boon to regional industries in most cases. However, detrimental consequences were recorded in other parts of the country.

Using natural resource wealth to promote economic growth has proven difficult for developing economies. There has been a mixed bag of results, with some winners (Such as Botswana and Malaysia) as well as several losers. Venables (2016) [100] discussed the difficulties in effectively managing resource riches, as well as the evidence on national achievement and the causes for dismal outcomes. Cockx and Francken (2016) [101] filled a gap in the knowledge of the "Resource Curse" by offering novel perspectives on how natural resource richness influences political goals and spending behaviors. The intricacies and structural adjustment of the "curse" were jointly stressed by Papyrakis (2017) [102] -its presence/intensity is mostly situationally dependent on the sort of resources, political mechanisms, and links with the rest of the economy.

Cluster 1: Red herring

As seen in Figures 22 and 23 and Table 7, the second largest Cluster was Cluster 1, comprising 123 references over 9 years from 2002 to 2012. Cluster 1 had a silhouette value of 0.856 . Carrot2 was used once more to delve further into Cluster 1 . According to the foam tree visualization, Cluster 1's key principles include human capital, resource wealth, public goods, panel data, mineral resources, migration, extractive sector, transition, and public investment. Figure 23 shows that this cluster was considerable in terms of citation frequency and explorations importance with high-profile references.

More specifically, Papyrakis and Gerlagh (2007) [103] provided statistical evidence for the so-called Resource Curses and concluded that this paradox might be a red herring. The most widely used indicator of "resource abundance" can be better understood as a surrogate for "resource dependency", which is inherent to fundamental structural variables. Van der Ploeg and Poelhekke (2010) [104] offered cross-country findings showing the Resource Curse was a "red herring" once the causality of resource exports was considered and resource abundance could influence growth. The same research implied that resource exports or rents promote growth in prosperous nations while making existing dynamic countries more unstable and lowering potential growth. 


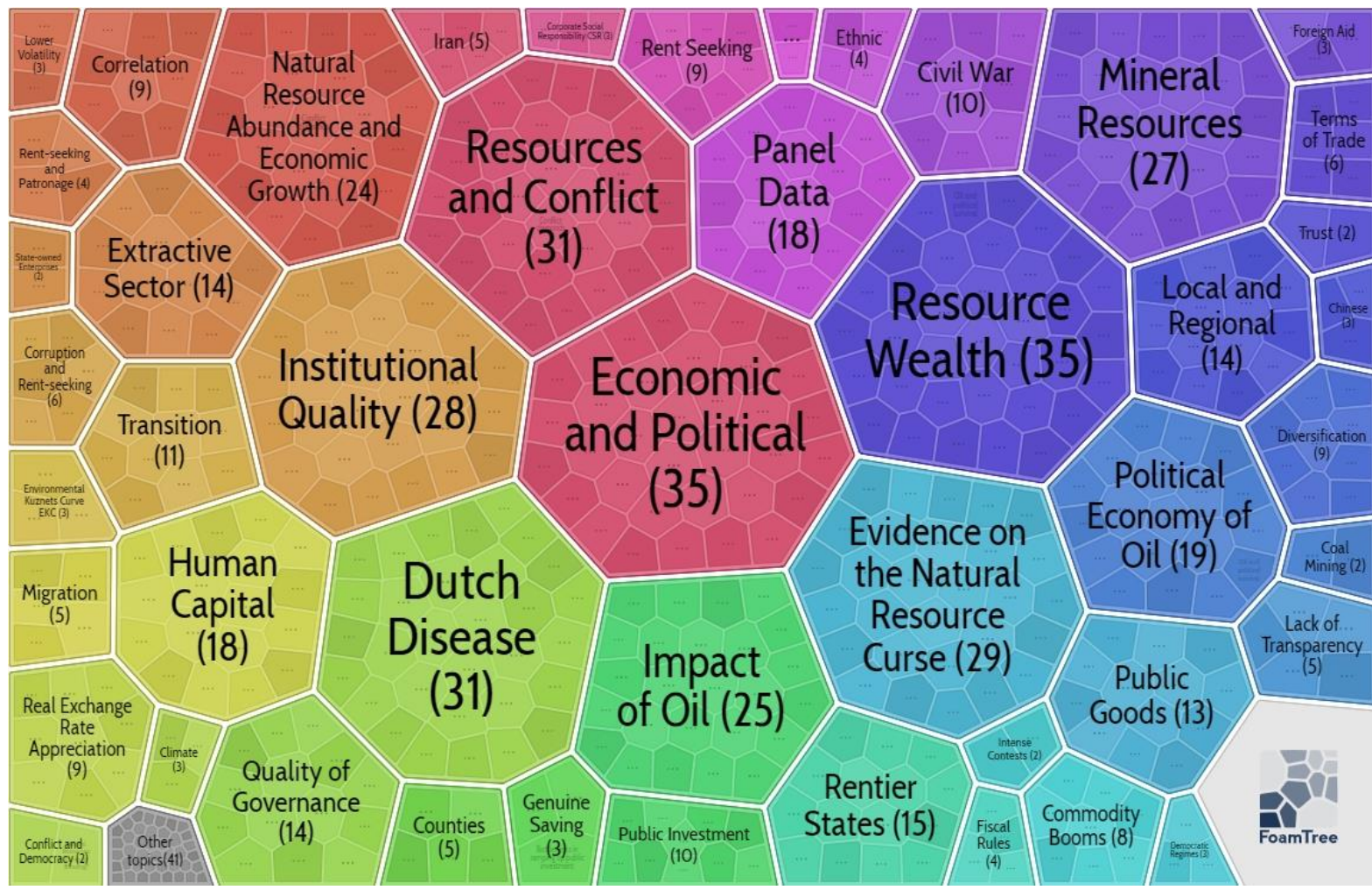

Figure 22. Keywords in Cluster 1 (using Carrot2 4.3.1).

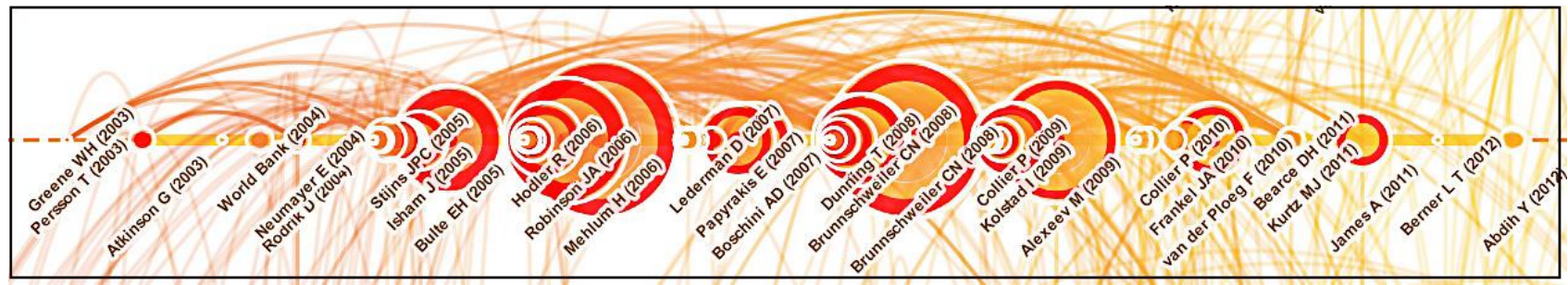

Figure 23. A timeline visualization of the Cluster 1 co-citation network (using Citespace 5.7.R4).

Table 7. Exploration and summary of Cluster 1.

\begin{tabular}{cccccc}
\hline Freq & Burst & Author & Year & Source & HalfLife \\
\hline 26 & 13.3 & Bulte EH & 2005 & World Development & 3.5 \\
17 & 9.56 & Isham J & 2005 & The World Bank Economic Review & 3.5 \\
13 & 7.3 & Stijns JPC & 2005 & Resources Policy & 3.5 \\
65 & 30.5 & Mehlum H & 2006 & The Economic Journal & 3.5 \\
37 & 18.8 & Robinson JA & 2006 & Journal of Development Economics & 3.5 \\
20 & 10.1 & Hodler R & 2006 & European Economic Review & 2.5 \\
19 & 8.75 & Boschini AD & 2007 & The Scandinavian Journal of Economics & 3.5 \\
15 & 8.3 & Papyrakis E & 2007 & European Economic Review & 3.5 \\
57 & 26.4 & BrunnschweilerCN & 2008 & Journal of Environmental Economics & 2.5 \\
26 & 11.9 & BrunnschweilerCN & 2008 & and Management & 2.5 \\
23 & 11.5 & Dunning T & 2008 & World Development & 3.5 \\
38 & 17.3 & Alexeev M & 2009 & The Review of Economics and Statistic & 3.5 \\
16 & 7.91 & Collier P & 2009 & European Economic Review & 2.5 \\
18 & 7.51 & Kolstad I & 2009 & World Development & 2.5 \\
19 & 9.68 & van derPloeg F & 2010 & Journal of Environmental Economics & 3.5 \\
16 & 7.24 & James A & 2011 & Resource and Energy Economics & 3.5 \\
\hline
\end{tabular}


Bulte et al. (2005) [105] suggested that the "Resource Curse" is a broader occurrence than previously thought. The consequences of diverse resource kinds for key areas of administration and individual welfare varied significantly. Isham et al. (2005) [106] demonstrated how countries reliant on limited natural resources and agricultural products are inclined to increase economic and social divisions, as well as diminished institutional capabilities.

Natural resource-rich countries are both economic failures and economic successes. According to Mehlum et al. (2006) [33,107], institutions were crucial inside the Resource Curse. Robinson et al. (2006) [108] suggested that knowing whether resource surpluses were a blessing or a curse depended on the political motivations they engender. Resource explorations would be expected to favor countries with systems that encouraged accountability and governmental competency. Countries that lack such systems may face a Resource Curse. Natural resources, Hodler (2006) [109] believed, could cut incomes in fractionalized nations but increase wages in homogeneous nations.

Pettersson et al. (2007) [110] also showed that mineral-rich countries were cursed only if their institutions were of poor quality. In contrast, if institutions were valid, the curse was reversed. Brunnschweiler (2008) [111] discovered that natural resource availability and economic development positively impacted empirical relations. They also found no evidence of natural resource-related detrimental indirect impacts via the institutional route. The book written by Dunning, T (2008) [112] debunked the widespread belief that natural resource riches breeds tyranny. Alexeev and Conrad (2009) [113] demonstrated that, in contrast to recent studies, a substantial supply of oil and other mineral wealth had a net beneficial effect on a country's long-term macroeconomic prosperity.

Collier and Hoeffler (2009) [114] claimed that resource-rich countries had a history of being dictatorial and misusing their natural resources. As a result, resource-rich economies required a unique sort of democracy with powerful controls and balances. Transparency is becoming important in the fight against bribery and other ills in resource-rich emerging nations. However, transparency, according to Kolstad and Wiig (2009) [115], is inadequate and must be supplemented by other forms of policy. Despite considering for state-specific impacts, Alex James and Aadland (2011) [116] demonstrated that resource-dependent counties had more anaemic growth in the economy.

Cluster 2: Economic growth

As seen in Figures 24 and 25 and Table 8, Cluster 2 remained active from 2006 to 2016; Cluster 2 has the highest significant citation explorations record with 11 papers/books having citation explorations between 2011 and 2016, split into two periods, the first from 2006 to 2012 and the second from 2013 to 2016. This Cluster included 105 references spanning the years. The silhouette value of 0.871 shows that the Cluster was highly consistent. Cluster 2's core concepts reflect crucial achievements in economic growth, oil producers, minerals, civil war, armed conflict, rentier state, mining activity, local communities, and extractive industries, according to the foam tree visualization.

Natural resource riches have the potential to have an enormous influence on the economies and politics of exporting regions. We have witnessed the startling and devastating effects of this wealth over the previous quarter-century, resulting in what is now recognized as the "Resource Curse". Natural resource-rich countries, such as those rich in oil and gas, frequently perform worse than their impoverished neighbors. Their resource richness frequently results in lower prospects of development, increased volatility, increased bribery, and, in the worst-case scenario, deadly civil wars.

From 2001, numerous scholars looked into the so-called "political Resource Curse", which asserts that mineral resource richness has a negative impact on a country's administration. Now there is substantial proof that one sort of natural riches, oil, has at least three negative consequences: it enhances totalitarian governments, exacerbates specific sorts of bribery, and contributes to the onset of armed conflict in low- and middle-income nations. 


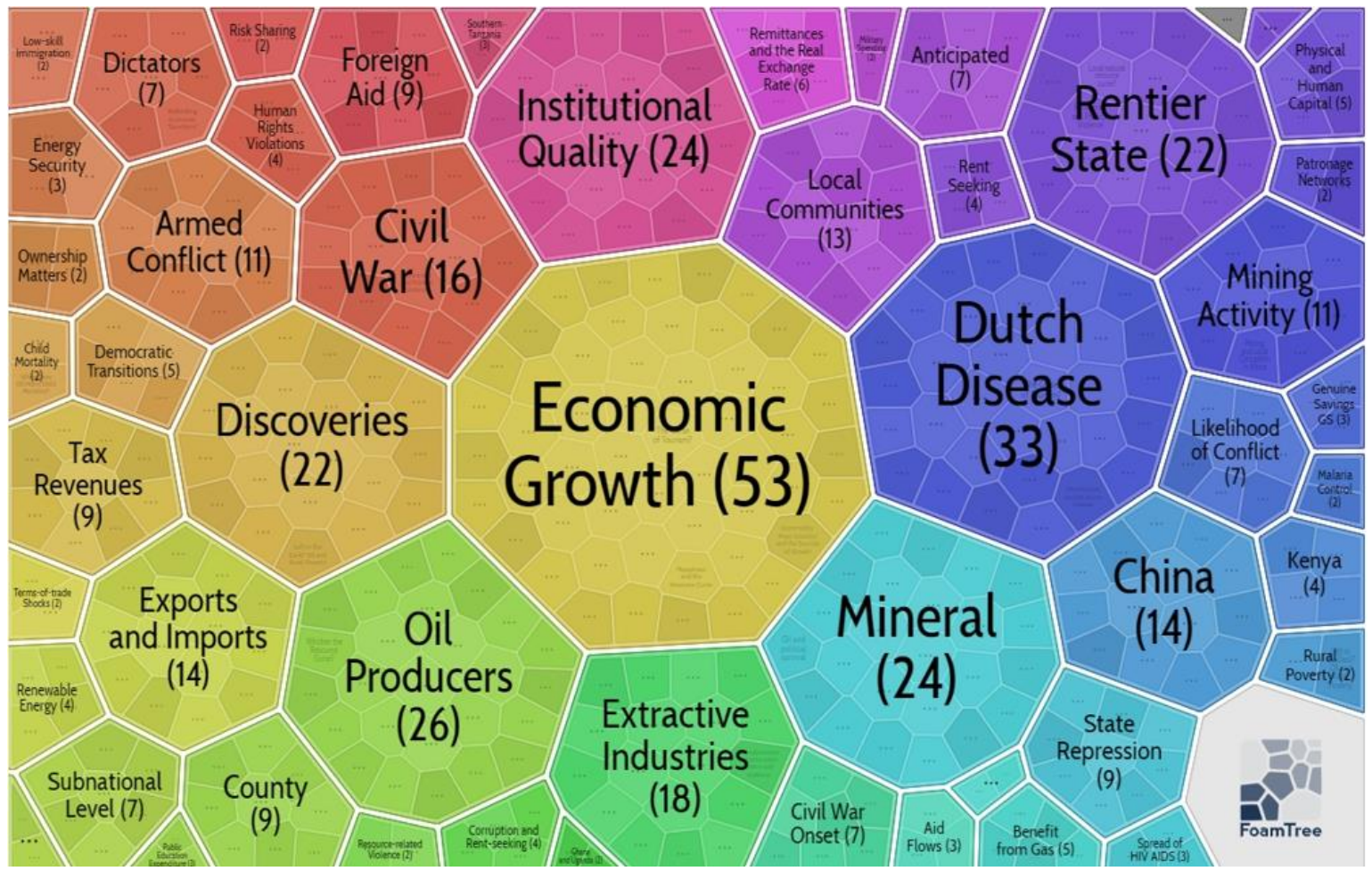

Figure 24. Keywords in Cluster 2 (using Carrot2 4.3.1).

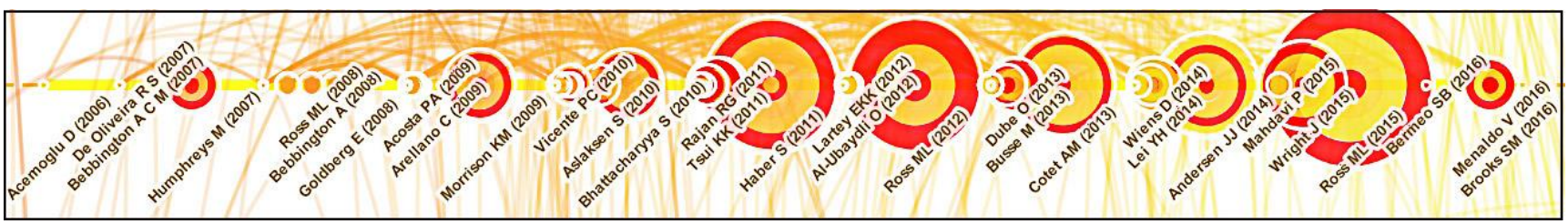

Figure 25. A timeline visualization of the Cluster 2 co-citation network (using Citespace 5.7.R4).

Table 8. Exploration and summary of Cluster 2.

\begin{tabular}{|c|c|c|c|c|c|}
\hline Freq & Burst & Author & Year & Source & HalfLife \\
\hline 13 & 5.97 & Humphreys M & 2007 & Escaping the Resource Curse & 3.5 \\
\hline 18 & 8.17 & Morrison KM & 2009 & International Organization & 3.5 \\
\hline 18 & 8.12 & Bhattacharyya S & 2010 & European Economic Review & 3.5 \\
\hline 12 & 6.63 & Aslaksen S & 2010 & Journal of Peace Research & 3.5 \\
\hline 6 & 3.57 & Luong Pauline Jones & 2010 & Oil Is Not a Curse & 3.5 \\
\hline 49 & 21.9 & HaberS & 2011 & American Political Science Review & 3.5 \\
\hline 15 & 8.3 & Tsui KK & 2011 & The Economic Journal & 2.5 \\
\hline 13 & 6.31 & Rajan RG & 2011 & Journal of Development Economics & 3.5 \\
\hline 8 & 4.31 & Ramsay KW & 2011 & International Organization & 2.5 \\
\hline 51 & 24 & Ross ML & 2012 & The Oil Curse & 3.5 \\
\hline 29 & 10.5 & CotetAM & 2013 & $\begin{array}{c}\text { American Economic Journal: } \\
\text { Macroeconomics }\end{array}$ & 2.5 \\
\hline 13 & 5.9 & Busse $\mathrm{M}$ & 2013 & Public Choice & 3.5 \\
\hline 12 & 5.44 & Dube $\mathrm{O}$ & 2013 & The Review of Economic Studies & 3.5 \\
\hline 9 & 4.19 & Andersen JJ & 2013 & Journal of Development Economics & 1.5 \\
\hline 32 & 11.1 & Andersen JJ & 2014 & Comparative Political Studies & 2.5 \\
\hline 11 & 5.46 & Wiens D & 2014 & Political Research Quarterly & 2.5 \\
\hline 11 & 5.26 & Ahmadov AK & 2014 & Comparative Political Studies & 3.5 \\
\hline 64 & 19.6 & Ross ML & 2015 & Annual Review of Political Science & 3.5 \\
\hline 22 & 5.16 & Wright J & 2015 & British Journal of Political Science & 2.5 \\
\hline 11 & 4.12 & Brooks SM & 2016 & International Organization & 3.5 \\
\hline
\end{tabular}


The first period from 2006 to 2012 had some outstanding research articles. For instance, Humphreys et al. (2007b) [117] spoke on the essential pathways created through such wealth, as well as the essential choices a nation should undertake whenever confronted with natural resource wealth. Morrison (2009) [118] claimed that higher nontax revenue would be linked to lower elite taxes in democracy, higher social expenditures in autocracies, and more security in both regime forms. If the efficiency of democratic systems was low, Bhattacharyya and Hodler (2010) [119] predicted that resource rents would cause a rise in corruption. When national fixed effects were taken into consideration, Aslaksen (2010) [120] showed that the association between oil and democratization was adverse. The book written by Bayulgen (2012) [121] claimed that the institutional structure of those mineral-rich states selected to govern their mineral resources had cursed them. However, rises in resource dependence were not linked to autocracy, according to Haber and Menaldo (2011) [122]. Tsui (2011) [123] analyzed the importance of oil riches on democracies, implying that politicians could be more concerned with the total amount of oil riches rather than the per capita worth. Aid imports, according to Rajan and Subramanian (2011) [124], had a systematically negative impact on a country's efficiency. Rajan and Subramanian (2011) [124] examined the effects of foreign aid on the growth of manufacturing and found that aid inflows have systematic adverse effects on a country's competitiveness, as reflected in the lower relative growth rate of exportable industries. They provided evidence suggesting that the channel for these effects is the real exchange rate appreciation caused by aid inflows and explained why it is hard to find robust evidence that foreign aid helps countries grow.

Ramsay (2011) [125] developed a straightforward model of the link between resource wealth and political liberty. Busse and Gröning (2011) [126] demonstrated that natural resource exports resulted in a surge in corruption.

The second period from 2013 to 2016, raised some queries. More purposefully, Dube and Vargas (2013) [127] proposed two opposing outcomes. Higher wages reduced conflict when labor was employed to grab resources violently. Increases in debatable earnings enhance violence by increasing appropriation gained. Natural resource wealth, according to political economy hypotheses related to the "natural Resource Curse" was a decisive factor regarding how long politicians stay in power. More specially, Jørgen Juel Andersen and Aslaksen (2013b) [128] discovered that the impact of various resource riches on political survival was influenced by both governments and resource varieties. After the revolutionary upheavals of the 1970s, Jørgen J. Andersen and Ross (2013a) [129] contended, that oil resources represented an impediment to transition to democracy, allowing developing nation governments to collect the oil revenues that western corporations had formerly sucked away. Wiens et al. (2014) [130] discovered that increasing resource reliance reduces an autocracy's chances of becoming democratic in the long and short periods but has little influence on democrats' chances of surviving.

Oil had an unintended detrimental effect on democracies, according to Ahmadov (2013) [131], because of its negative influence on education. Researchers have also progressed in their comprehension of the processes that contribute to these consequences, as well as the circumstances that render them more probable. For instance, Oil income, according to Wright et al. (2013) [132], raised defense funding in authoritarianism, implying that greater oil riches could dissuade revolutions that might lead to civil war. In contrast, Brooks and Kurtz (2016) [133] re-examined the link among oil profits and governmental systems, arguing that such natural resource rents do not necessarily contribute to autocratic consequences.

\section{Cluster 5: Conflict diamond}

As seen in Figures 26 and 27 and Table 9, Cluster 5 remained active from 2000 to 2007; with an earlier citation exploration. Cluster 5 had the most significant citation explorations, split into two periods, the first from 2000 to 2003 and the second from 2003 to 2007. This Cluster included 83 references spanning the years. The silhouette value of 0.898 shows that the Cluster was highly consistent. Cluster 5's core concepts reflect crucial 
research in resource rents, conflict diamonds, oil production, rentier states, civil war onset, property rights, oil gaps, rebel groups, and institutional quality, according to the foam tree visualization.

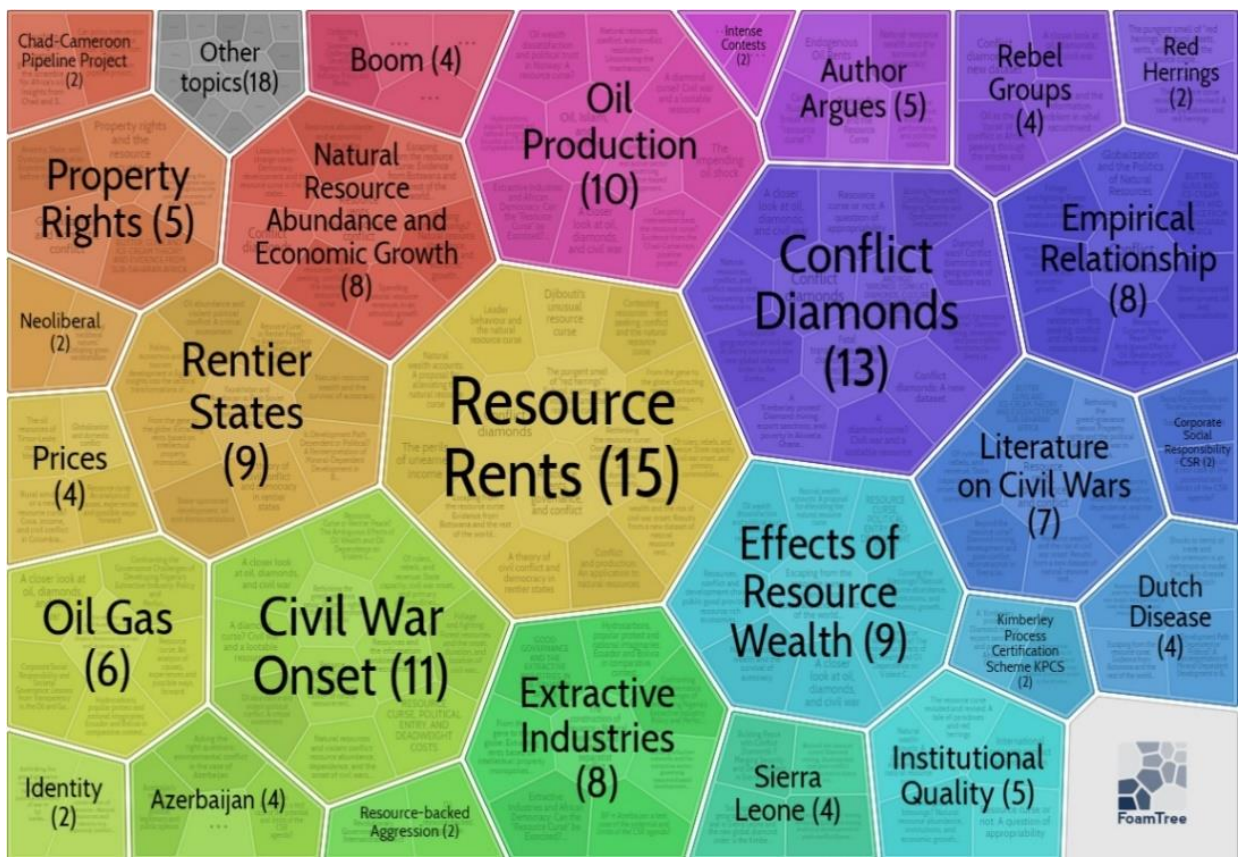

Figure 26. Keywords in Cluster 5 (using Carrot2 4.3.1).

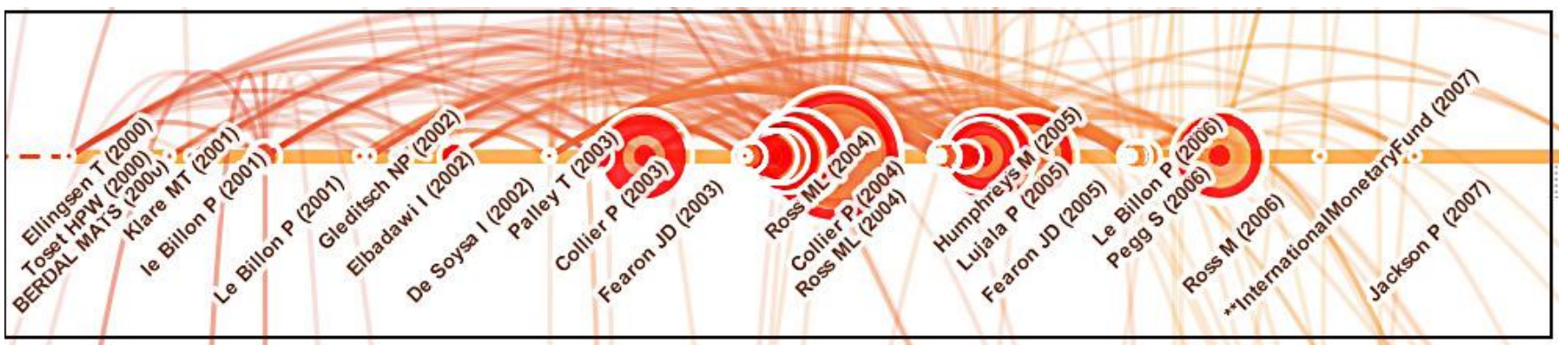

Figure 27. A timeline visualization of the Cluster 5 co-citation network ${ }^{* *}$ means public publications from government or non-government organizations).

Many armed groups depended on mineral resources earnings, such as oil, lumber, and diamonds, to supplement diminishing Cold War backing in the 1990s. Resources fueled, but also drove, wars, and created power tactics focused on the commercialization of military conflict and territorialization of authority around lucrative resource regions and markets. As a result, military action in the post-Cold War era is largely characterized by world politics that is tightly related to the geographies and political economics of natural resources. Some contemporary civil war studies claim that greed, rather than grievance, is the driving force behind the conflict, based on a strong empirical link between primary commodity exports and military coups. Civil war represents a major problem in globalization. Civil wars may significantly stifle a country's growth, particularly in low-income nations where military conflict is more likely.

More specifically, Le Billon (2001) [134] looked at ideas on the links between resources and violent conflicts, as well as the historical dynamics that underpin them. Alternative viewpoints that consider need-, creed-, and governance-based reasons as intricately tied to the problems of primary products reliance and violence were compared by Soysa 
(2002) [135].The book titled Breaking the Conflict Trap [136] highlighted the devastating effects of civil conflict on industrialization.

Table 9. Exploration and summary of Cluster 5.

\begin{tabular}{cccccc}
\hline Freq & Burst & Author & Year & Source & HalfLife \\
\hline 11 & 6.82 & Le Billon P & 2001 & Political Geography & 3.5 \\
9 & 5.49 & De Soysa I & 2002 & Journal of Peace Research & 2.5 \\
16 & 8.95 & Fearon JD & 2003 & American Political Science Review & 4.5 \\
9 & 5.03 & Collier P & 2003 & Breaking the Conflict Trap & 1.5 \\
26 & 13.5 & Ross ML & 2004 & Journal of Peace Research & 2.5 \\
25 & 13 & Collier P & 2004 & Oxford Economic Papers & 3.5 \\
16 & 9.33 & Jensen N & 2004 & Comparative Political Studies & 3.5 \\
18 & 9.32 & Ross ML & 2004 & International Organization & 2.5 \\
13 & 6.72 & Smith B & 2004 & American Journal of Political Science & 2.5 \\
8 & 4.47 & Collier P & 2004 & Journal of Peace Research & 1.5 \\
20 & 9.54 & Fearon JD & 2005 & Journal of Conflict Resolution & 2.5 \\
14 & 6.67 & Lujala P & 2005 & Journal of Conflict Resolution & 2.5 \\
10 & 5.82 & Collier P & 2005 & Journal of Conflict Resolution & 2.5 \\
19 & 9.58 & Ross M & 2006 & Journal of Conflict Resolution & 3.5 \\
\hline
\end{tabular}

Michael L. Ross (2004) [137] claimed that, firstly, oil raised the risk of war, especially secessionist conflict. Secondly, "lootable" goods such as emeralds and drugs seemed to prolong established conflicts. Thirdly, there was no obvious connection between legitimate agricultural commodities and civil conflict. Lastly, the link between commodities and the emergence of civil conflict was weak. Collier and Hoeffler (2004) [138] discovered that the most evident political and societal factors linked to complaints had limited predictive value.

Jensen and Wantchekon (2004) [139] proposed a solid and unfavorable link between the existence of large natural resource industry and the degree of democracy in Africa, arguing that resource-rich nations such as Nigeria might become democratic if they implemented strong vertical and transparency structures. Michael Ross (2004) [140] investigated the factors underlying the resource conflict association by looking at 13 previous military conflicts. Smith (2004) [141] discovered that oil wealth is strongly linked to improved governmental stability, as well as a decreased risk of military conflict and antigovernmental demonstrations. Collier et al. (2004) [142] demonstrated that the length of a conflict is consistently tied to the fundamental circumstances that existed before the conflict and the conditions that existed throughout the war. Exogenous measurements of oil, gasoline, and gemstone riches, according to Michael Ross (2006) [143], were strongly linked to the advent of civil conflict. He also discovered that the extraction of oil and diamonds caused civil conflicts via separate methods.

5.4.2. Research References of High Citation Frequency, Citation Explorations, and Significant Centrality

CiteSpace is well known for its efficiency in scrutinizing the references with correlated subjects. Using another clustering method by CiteSpace, the author rebuilt a network of references from 1993 to 2020 of the leading 50 articles' references with the largest quotations yearly since science foundations attained a certain degree and progressed dramatically during this time. Figure 28 reveals the landscape view and includes 1766 references after synthesizing the 27 special networks. The high modularity of the network yields a score of 0.4741, indicating that "Resource Curse", "Dutch Disease", and "Conflict resource" are all specialties and are well established in terms of co-citation clusters. Since there were some large clusters, the average co-citation network in diverse clusters has distinctive hues. As seen in Figure 28, showing when the co-citation connections first emerged. In earlier times, connections with darker hues were created in the following order: ink red, dark red, light red, orange, and yellow. The title terms of citing papers to the Cluster are used 
to identify each Cluster. The red Cluster on the bottom, for example, is labeled "\#50 gas industry", proving that articles about the gas industry have cited Cluster 50. More specifics details on the major clusters can be identified in Table 10. Cluster 0, for example, was the largest Cluster with 185 documents. Most clusters had strong silhouette, implying that these clusters were identical.

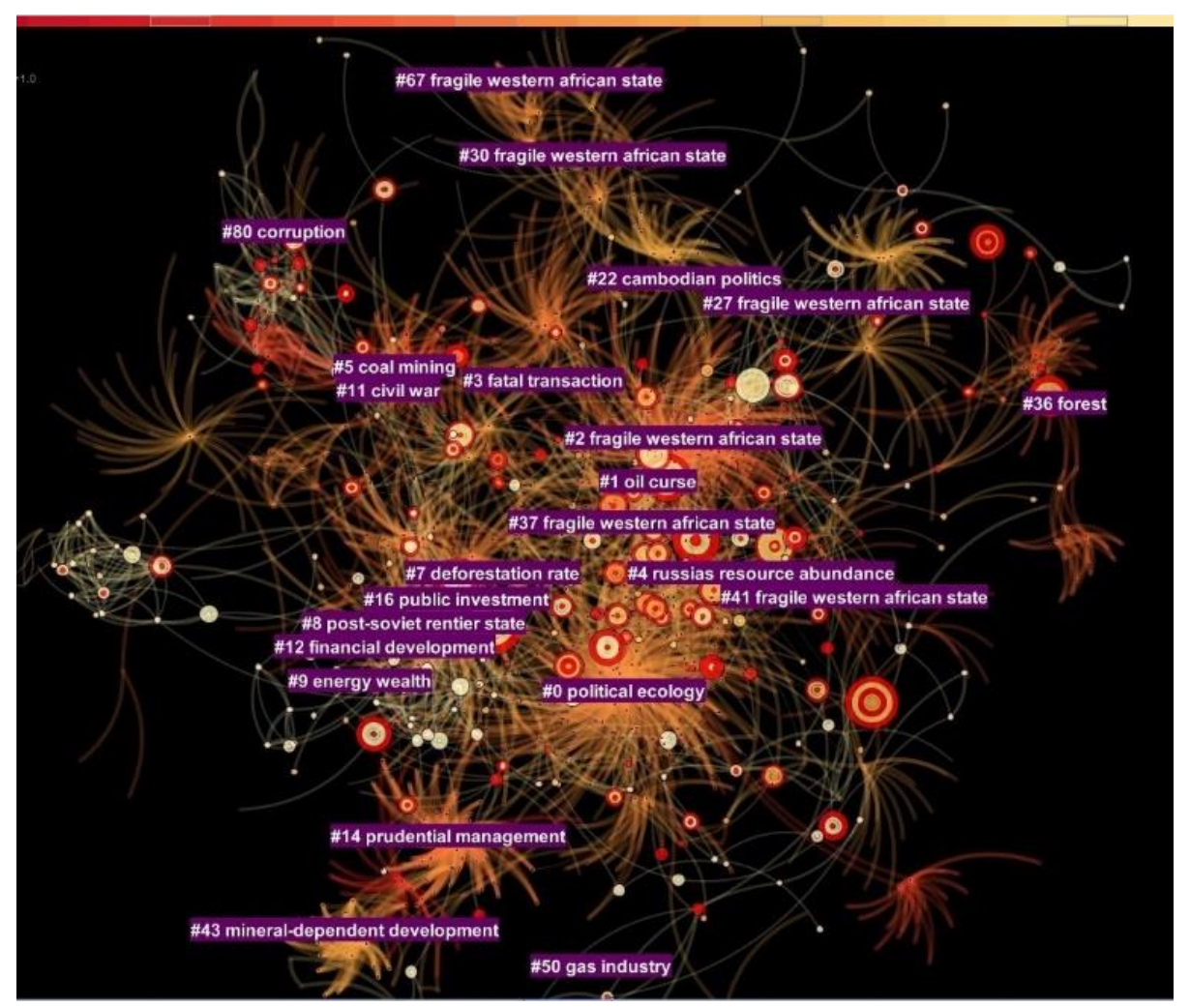

Figure 28. The landscape picture of the reference co-citation framework from 1993-2020.

Meanwhile, the most recent references appeared in Cluster 1, 16, and 50 in 2017. the author measured the clusters' longevity in terms of time and assigned,+++++++++ , and +++ to the top 1-5 clusters. Clusters 9 and 16, for example, had the greatest sustainability, with a period of up to 15 years. The author assumed the cluster as still active if its members published in the last 3 years; otherwise, it was deemed inactive. As a result, just five of the 20 major clusters were considered now active, and their average year is all after 2008. The title of the referenced articles was used to mark the clusters' themes. According to the five active clusters, Clusters 1, 4, and 50 are all connected to energy policies. In contrast, Clusters 12, 16 are for financial development and public investment. CiteSpace provides a timeline view accompanied by a landscape view; both can list the clusters' horizontal timelines and illustrate the evolution of the whole science domain. The hues of the co-citation networks illustrate the year whenever the co-citations emerged, as shown in Figure 29, with darker colors such as ink red implying that the connections were created previously. 
Table 10. Temporal properties of major clusters.

\begin{tabular}{|c|c|c|c|c|c|c|c|c|c|}
\hline ID & Size & Silhouette & From & To & Last & Mean & Duration & Activeness & Themes \\
\hline 0 & 185 & 0.991 & 2002 & 2007 & 5 & 2004 & & inactive & $\begin{array}{l}\text { political ecology; economic growth; natural resource } \\
\text { abundance; financial development }\end{array}$ \\
\hline 1 & 157 & 0.943 & 2004 & 2017 & 13 & 2010 & ++++ & active & $\begin{array}{l}\text { oil curse; state incentive; intrastate armed conflict; } \\
\text { natural resources matter; resource rent }\end{array}$ \\
\hline 2 & 120 & 1 & 1999 & 2005 & 6 & 2002 & & inactive & $\begin{array}{l}\text { fragile western African state; rights diagnostics; } \\
\text { making hydrocarbon extraction work }\end{array}$ \\
\hline 3 & 99 & 1 & 1998 & 2008 & 10 & 2003 & +++ & inactive & $\begin{array}{l}\text { fatal transaction; terrorist consumer; conflict } \\
\text { diamond; Sierra Leone }\end{array}$ \\
\hline 4 & 98 & 1 & 2001 & 2009 & 8 & 2005 & ++ & inactive & $\begin{array}{l}\text { Russia's resource abundance; post-communist } \\
\text { political economy; resource curse; natural resource }\end{array}$ \\
\hline 5 & 92 & 0.986 & 2008 & 2019 & 11 & 2014 & ++++ & active & $\begin{array}{l}\text { coal mining; subnational resource curse; natural } \\
\text { resource boom; oil curse; resource curse }\end{array}$ \\
\hline 7 & 83 & 1 & 1999 & 2006 & 7 & 2003 & & inactive & $\begin{array}{l}\text { deforestation rate; interaction effect; forest cover; red } \\
\text { herring; long-run economic development }\end{array}$ \\
\hline 8 & 80 & 1 & 2004 & 2007 & 3 & 2005 & & inactive & $\begin{array}{l}\text { post-soviet rentier state; double curse; resource } \\
\text { income; resource curse; natural resource }\end{array}$ \\
\hline 9 & 78 & 0.989 & 1996 & 2011 & 15 & 2004 & +++++ & inactive & $\begin{array}{l}\text { energy wealth; tax reform; institutional capacity; } \\
\text { domestic constraint; ownership structure }\end{array}$ \\
\hline 11 & 75 & 0.979 & 1998 & 2005 & 7 & 2001 & & inactive & $\begin{array}{l}\text { civil war; new dataset; assessing NGO report; private } \\
\text { sector role; African resource conflict }\end{array}$ \\
\hline 12 & 64 & 0.98 & 2011 & 2020 & 9 & 2016 & ++ & active & $\begin{array}{l}\text { financial development; energy price; extractive } \\
\text { industries transparency initiative }\end{array}$ \\
\hline 14 & 63 & 0.99 & 2001 & 2005 & 4 & 2003 & & inactive & $\begin{array}{l}\text { prudential management; resource-rich transition } \\
\text { economies; hydrocarbon revenue }\end{array}$ \\
\hline 16 & 55 & 0.953 & 2002 & 2017 & 15 & 2008 & +++++ & active & $\begin{array}{l}\text { public investment; sierra leone; post-conflict } \\
\text { reconstruction; good governance; building peace }\end{array}$ \\
\hline 22 & 48 & 0.974 & 2005 & 2017 & 4 & 2007 & & inactive & $\begin{array}{l}\text { Cambodian politics; oil boom; resource curse; policy } \\
\text { maker; theoretical overview }\end{array}$ \\
\hline 27 & 43 & 1 & 2002 & 2010 & 8 & 2006 & ++ & inactive & $\begin{array}{l}\text { fragile western African state; rights diagnostics; } \\
\text { making hydrocarbon extraction work }\end{array}$ \\
\hline 30 & 41 & 1 & 2002 & 2006 & 4 & 2004 & & inactive & $\begin{array}{l}\text { governing gas; nontax revenue; oil revenue; } \\
\text { extractive developmental state; unconventional gas }\end{array}$ \\
\hline 36 & 35 & 0.994 & 1999 & 2003 & 4 & 2000 & & inactive & $\begin{array}{l}\text { forest; linkage; oil; macroeconomics; resource curse; } \\
\text { natural resource; economic growth }\end{array}$ \\
\hline 37 & 35 & 1 & 2004 & 2007 & 3 & 2005 & & inactive & $\begin{array}{l}\text { emerging oil economy; BRIC countries; Barry prize } \\
\text { essay; G7 countries; rich economies }\end{array}$ \\
\hline 41 & 31 & 1 & 1999 & 2005 & 6 & 2002 & & inactive & $\begin{array}{l}\text { local content issue; inefficient policy; resource curse } \\
\text { effect; building peace; red herring }\end{array}$ \\
\hline 43 & 29 & 0.984 & 2003 & 2007 & 4 & 2005 & & inactive & $\begin{array}{l}\text { mineral-dependent development; development path; } \\
\text { resource curse; natural resource }\end{array}$ \\
\hline 50 & 26 & 0.989 & 2012 & 2017 & 5 & 2014 & & active & $\begin{array}{l}\text { gas industry; Albertine region; Ghanaian } \\
\text { employment; local content; local content issue }\end{array}$ \\
\hline 67 & 19 & 0.998 & 2002 & 2006 & 4 & 2004 & & inactive & $\begin{array}{l}\text { transnational rule; cultural ecology; forest; dynamic } \\
\text { interaction; autocratic survival }\end{array}$ \\
\hline 80 & 14 & 0.996 & 2000 & 2006 & 6 & 2003 & & inactive & $\begin{array}{l}\text { corruption; mining; resource curse; natural resource; } \\
\text { economic growth }\end{array}$ \\
\hline
\end{tabular}




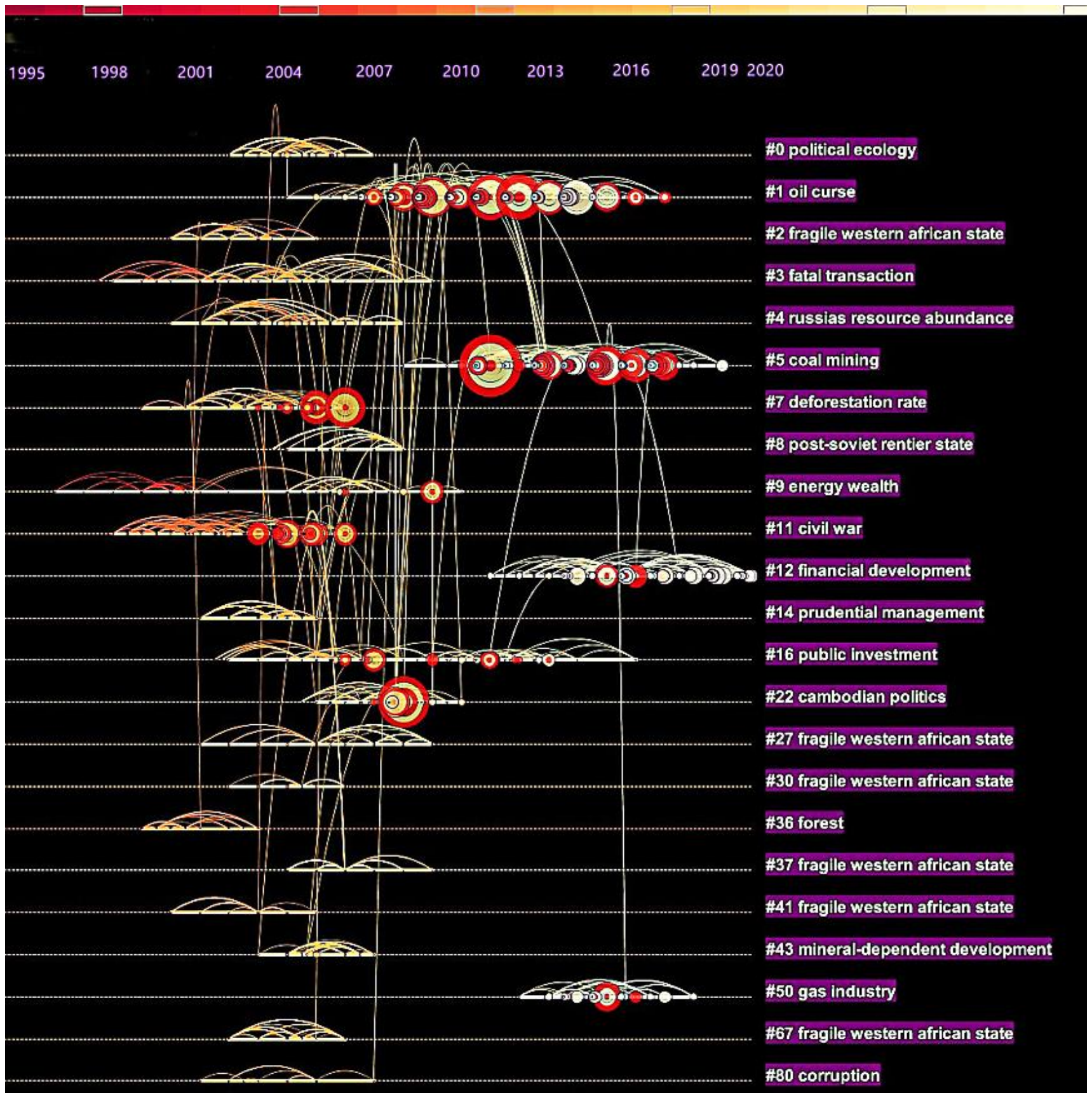

Figure 29. A timeline image of the reference co-citation framework during 1993-2020.

CiteSpace allows us to further explore the major clusters. The key sources and referring papers that help form new research trends for the three most vital clusters are presented in Tables A3-A8 (Appendix A). Despite being named "Resource Curse", Cluster 1 was primarily cited by papers on the oil curse and resource conflict. In contrast, Cluster 7 was primarily cited by papers on forest coverage and deforestation's consequences. Cluster 7 was more closely related to research on "ecological economics" than research on "Resource Curses". As a result, only two of the six active clusters were connected to the Resource Curse: Cluster 12 was primarily concerned with financial development and the energy industry, Cluster 16 is concerned with public investment and peacebuilding, and Cluster 50 was associated with the natural gas industry and localization policy.

The nodes with ink red color or blue tree rings were evaluated. Node size the describes reference frequency with large tree rings. The first author and the publication 
year are labeled in Figure 29, with four influential articles cited over 600 times, including $[5,33,144,145]$. Only one of them was published in 2017, while the other three were published from 2015 to 2016. One explanation is that citation-based research seems to undervalue recently published articles [146]. In addition to the four articles, other articles with vital citation records belong to the following three clusters: "Cluster 1 oil curse", "Cluster 5 coal mining", and "Cluster 7 deforestation rate". These widely cited articles are the foundation of research in this field, which has developed rapidly since 2005.

More precisely, van der Ploeg (2011) [5] disclosed that resource-rich developing economies could not effectively turn their finite capital into other productive benefits when it depletes. Ross (2015) [145] examined hundreds of research that claimed that natural resource capital has a detrimental effect on a country's administration. He went over the evidence for these assertions and uncovered some mysteries for potential study.

During 1993 and 2020, the program's red endpoints indicated references with citation explosions. Citation explosions are a sign of a burgeoning field of study. Citation explosions are the discovery of an explosive event that may span many years or just 1 year. A citation explosion shows that a certain article is linked to an increase in references. To put it another way, the paper received a great deal of scrutiny from the research world. Additionally, if a Cluster includes a large number of nodes with high citation eruptions, the group as a whole represents an active research field or a recent phenomenon. The explosion detection in CiteSpace is based on Kleinberg's algorithm [147].

Among the 156 red nodes, 109 nodes had citations explosions that started after 2012, whereas 80 nodes had explosions starting after 2015. Citation explosions, which last an average of 3.2 years, need to wait an average of 4.3 years after publication. "Cluster 0 Political ecology", "Cluster 1 oil curse", and "Cluster 2 fragile western African states" were the top three clusters with the most citation explosions. The top 15 articles with the most robust citation explosions are introduced in Table 11. Most of the 15 references seem to have been published in prominent journals with significant impact factors.

Table 11. Top 15 references of the most citation explorations.

\begin{tabular}{|c|c|c|c|c|c|c|c|c|}
\hline Rank & Burst & Freq & Degree & First Author & Year & Source & Half-Life & ID \\
\hline 1 & 44 & 81 & 4 & van der Ploeg F & 2011 & Journal of Economic literature & 3.5 & 3 \\
\hline 2 & 34 & 65 & 5 & Mehlum $\mathrm{H}$ & 2006 & The economic journal & 3.5 & 3 \\
\hline 3 & 31 & 57 & 9 & $\begin{array}{l}\text { Brunnschweiler } \\
\text { CN }\end{array}$ & 2008 & $\begin{array}{c}\text { Journal of Environmental Economics and } \\
\text { Management }\end{array}$ & 2.5 & 3 \\
\hline 4 & 29 & 53 & 6 & Ross M & 2012 & $\begin{array}{l}\text { The Oil Curse: How Petroleum Wealth Shapes the } \\
\text { Development of Nations }\end{array}$ & 3.5 & 2 \\
\hline 5 & 26 & 49 & 16 & Haber S & 2011 & American Political Science Review & 3.5 & 2 \\
\hline 6 & 21 & 38 & 10 & Robinson JA & 2006 & Journal of Development Economics & 3.5 & 3 \\
\hline 7 & 20 & 38 & 15 & Alexeev M & 2009 & The Review of Economics and Statistics & 3.5 & 2 \\
\hline 8 & 16 & 29 & 9 & Van Der Ploeg F & 2017 & Journal of Development Studies & 2.5 & 10 \\
\hline 9 & 16 & 32 & 15 & Andersen JJ & 2014 & Comparative Political Studies & 2.5 & 2 \\
\hline 10 & 16 & 30 & 1 & Gilberthorpe E & 2015 & The Extractive Industries and Society & 3.5 & 52 \\
\hline 11 & 15 & 29 & 2 & Venables AJ & 2016 & Journal of Economic Perspectives & 2.5 & 10 \\
\hline 12 & 15 & 26 & 11 & Caselli F & 2013 & American Economic Journal: Applied Economics & 2.5 & 2 \\
\hline 13 & 15 & 30 & 6 & Smith B & 2015 & Journal of Development Economics & 3.5 & 10 \\
\hline 14 & 14 & 29 & 24 & Cotet AM & 2013 & American Economic Journal: Macroeconomics & 2.5 & 2 \\
\hline 15 & 14 & 29 & 8 & James A & 2015 & Journal of Development Economics & 3.5 & 10 \\
\hline
\end{tabular}

More accurately, Mehlum et al. (2006) [33] claimed that differences in institutional efficiency were the primary explanation as to why countries abundant in natural resources were both development losers and winners. He proved that institutes played a crucial role in the Resource Curse. Brunnschweiler and Bulte (2008) [148] examined the empirical evidence for the Resource Curse and concluded that resource dependency had little impact on productivity, while resource scarcity significantly impacted growth and institutional efficiency. Ross (2012) [149] discovered a direct and essential connection between energy- 
rich countries having less democracy, less economic stability, and more civil wars, which he referred to as the "oil curse." Belonging to "Cluster 2 fragile western African states", Haber and Menaldo (2011) [122] created a specific database that enabled focusing on variation in resource dependency and regime styles across countries.

\subsection{Recent Potentially Transformative Papers}

In addition to analyzing citations, another approach to assess papers' impact is to examine how it has considerably altered the framework of prevailing research. Aiming at evaluating the groundbreaking potential of new references, the author utilizes the harmonic mean of three distinctions created by structural variance analysis utilizing CiteSpace, namely $\Delta M, \Delta C L w$ and $C k l$, following the methods introduced by Chen (2017) [46].

Table 12 provides a collection of papers with solid transformative potential between 2013 and 2020. All of them were concerned with the outcomes of the Resource Curse, proving that the most recent studies on "Resource Curse" are more frequent than research on "Dutch Disease" and "Conflict resource".

Table 12. Recent Potentially transformative papers.

\begin{tabular}{|c|c|c|c|c|c|c|c|}
\hline Rank & Year & $\Delta$ centrality & Freq & Entropy & References & Journal & Title \\
\hline 1 & 2014 & 0.09 & 14 & 1.56 & $\begin{array}{l}\text { Le Billon } \\
\text { Philippe. (2014) }\end{array}$ & $\begin{array}{l}\text { Third World } \\
\text { Quarterly }\end{array}$ & $\begin{array}{l}\text { Natural resources and corruption in post-war } \\
\text { transitions: matters of trust }\end{array}$ \\
\hline 2 & 2014 & 0 & 45 & 1.04 & Apergis N. (2014) & $\begin{array}{l}\text { Energy } \\
\text { Economics }\end{array}$ & $\begin{array}{c}\text { The oil curse, institutional quality, and growth in } \\
\text { MENA countries: Evidence from time-varying } \\
\text { cointegration }\end{array}$ \\
\hline 3 & 2014 & 0.08 & 36 & 1.24 & $\begin{array}{l}\text { Bhattacharyya S. } \\
\qquad(2014)\end{array}$ & $\begin{array}{l}\text { Oxford Economic } \\
\text { Papers }\end{array}$ & $\begin{array}{l}\text { Public capital in resource rich economies: is there a } \\
\text { curse }\end{array}$ \\
\hline 4 & 2020 & 0.04 & 0 & 1.04 & $\begin{array}{l}\text { Anser } \\
\text { Muhammad } \\
\text { Khalid. (2020) }\end{array}$ & Resources Policy & $\begin{array}{l}\text { Evaluating 'natural resource curse' hypothesis } \\
\text { under sustainable information technologies: A } \\
\text { case study of Saudi Arabia }\end{array}$ \\
\hline 5 & 2014 & 0.03 & 30 & 1.31 & Cockx L. (2014) & $\begin{array}{l}\text { Ecological } \\
\text { Economics }\end{array}$ & $\begin{array}{l}\text { Extending the concept of the resource curse: } \\
\text { Natural resources and public health }\end{array}$ \\
\hline 6 & 2014 & 0.13 & 68 & 1.31 & Koubi V. (2014) & $\begin{array}{l}\text { Journal of Peace } \\
\text { Research }\end{array}$ & $\begin{array}{l}\text { Do natural resources matter for interstate and } \\
\text { intrastate armed conflict }\end{array}$ \\
\hline 7 & 2014 & 0 & 24 & 1.04 & Wiens D. (2014) & $\begin{array}{l}\text { Political } \\
\text { Research } \\
\text { Quarterly }\end{array}$ & $\begin{array}{l}\text { The Political Resource Curse: An Empirical } \\
\text { Re-evaluation }\end{array}$ \\
\hline 8 & 2014 & 0.1 & 12 & 1.36 & Wiens D. (2014) & $\begin{array}{l}\text { Journal of } \\
\text { Theoretical } \\
\text { Politics }\end{array}$ & Natural resources and institutional development \\
\hline 9 & 2019 & 0.05 & 4 & 1.04 & $\begin{array}{l}\text { Hilmawan R. } \\
\text { (2019) }\end{array}$ & Resources Policy & An investigation of the resource curse in Indonesia \\
\hline 10 & 2020 & 0.03 & 0 & 1.04 & $\begin{array}{l}\text { Ampofo Gideon } \\
\text { Kwaku Minua. } \\
\text { (2020) }\end{array}$ & Resources Policy & $\begin{array}{l}\text { Total natural resource rents, trade openness and } \\
\text { economic growth in the top mineral-rich countries: } \\
\text { New evidence from nonlinear }\end{array}$ \\
\hline
\end{tabular}

More precisely, Le Billon (2014) [150] stressed the importance of transformation contexts, stakeholder incentives, and resource sector characteristics, as well as approaches to properly appreciate resource-related misuse in terms of confidence and mediation mechanisms. Apergis and Payne (2014) [151] re-examined the effect of oil surplus on economic growth in several North African and Middle Eastern states, finding that higher institutional output reduces the negative impact of oil reserves on real-economy performance. Bhattacharyya and Collier (2014) [152] concluded that resource rental substantially decreased the public productive capacity. Anser et al. (2020) [153] demonstrated the importance of technology-driven natural resource development in lowering the cost of natural resources and lowering carbon abatement prices. Cockx and Francken (2014) [154] expanded the concept of the Resource Curse by exploring whether and how natural resource capital affects social investment, as well as the transmission mechanisms via which it did so. Koubi et al. (2014) [155] examined the current theoretical and scientific evidence linking renew- 
able and nonrenewable natural resources to intrastate and interstate trade. Wiens et al. (2014) [130] discovered that growing resource dependency lowers an autocrat's probability of becoming democratic but had little impact on democracies' chances of survival. As Wiens (2014) [130] illustrated, direct calls for domestic structural change are unlikely to be successful. Hilmawan and Clark (2019) [156] explored the impact of resource dependency on district-level income and discovered a distinct good association among dependency, as measured by the share of total local government income through oil, natural gas, mining, and income in the most reliable parameters with equipment. Ampofo et al. (2020) [157] demonstrated that total natural resource rent hurts economic development in Australia, DR Congo, and India, confirming the "Resource Curse" hypothesis in these countries.

\section{Limitations}

This review had specific weaknesses that should be noted. First, the findings were performed within the sample rather than through all published articles. Research in this field is becoming increasingly provocative and complex, with many studies spanning dozens of disciplines. Although the author's sample is one of the widest in Resource Curses/Dutch Diseases/Conflict Resources literature reviews, it still had certain limitations.

The author used the Web of Science core collection database to get the material. Because of the wide usage in earlier research, this decision was considered rational $[61,158,159]$. Beyond this, the author proposed additional factors for previous research on this database described below.

Web of Science is one of the most comprehensive interdisciplinary databases of peerreviewed Social Science literature and one of the most prestigious and readily available databases, containing a listing of all or most renowned publications. It gives users powerful search capabilities as well as a simple method to simple and transport all relevant information for bibliometric research. It also features the second highest number of Resource Curse publications after Scopus, as well as more thoroughly verified research than ProQuest, EBSCO, Google Scholar, or Scopus.

Although the Web of Science core collection is one of the largest considerable abstracts and citation datasets of peer-reviewed publications, it may not include all Resource Curse studies. As a result, other databases, particularly the growing number of preprints accessible on Google Scholar and Scopus, might have contributed additional insights not accessible in this research domain. However, since the emphasis of this research was on detecting the fundamental structure rather than counting citations or co-citations, this problem was mitigated. This articles' findings are still crucial to our understanding of the landscape and evolution of Resource Curse/Dutch Disease/Conflict resource studies among political science, economics, and political economics.

Second, future research might dig into the scholars' social networks regarding mutual affiliations, institutional supervisor-student relationships, and work interactions. Therefore, the evolution of these social relationship frameworks is crucial for understanding the academic advancement of the Resource Curse/Dutch Disease/Conflict resource literature, which was insufficiently investigated in this article.

Third, the author focused on a broad overview of the evolution of Resource Curse theories in this article. This article aims to outline the general advancement of this domain. Future analysis may review the fundamental structure of each discipline domain in greater detail. Maps could not be presented for each thesis due to page constraints. The landscape and evolution of Resource Curse hypotheses could be the basis of future research. Future scholars, the author expects, will use bibliographic visualization approaches to code the key influential publications inside a field to plot the frontiers of each subject of the Resource Curse/Dutch Disease/Conflict resource research and the interaction among various subdomains. In the future, it might be necessary to focus on a particular topic, such as the relationship between transformational studies and the connection between the domains.

Fourth, this bibliometric analysis method had its own limitations. Since citations take time to accumulate, relying on multiple citations can reduce important patterns, 
particularly in more recent research. The overall citation ranking for more recent years of publications is typically lower. This may be because of their research's lower influence on academia, however, metrics may overlook the faster period it took for citations to accumulate for this theme. It is debatable whether citations should be a substitute for the importance of scientific contributions [160,161], because of the scope for deception and the lack of understanding of the article cited. As a result, the scientometric study analysis here should not be interpreted as an affirmation of the highlighted research works' correctness, meaning, or efficacy. Instead, the analysis can represent the field's evolution. Science categories, publications, concepts, and sources have all contributed to the present status of the Resource Curse/ Dutch Disease/ Conflict resource science domain.

\section{Conclusions}

This article provided a thorough framework review of the Resource Curse, Dutch Disease, and Conflict resource literature from 1993 to 2020. Hopefully, the analytical milestones of this domain can provide us with some insight for coping with the tumultuous sub-Saharan African zones and other areas with abundant resources but low economic prosperity. The findings revealed previously unnoticed details regarding the composition, trends, and changes of the Resource Curse domain, paving the road for potential study. The most noteworthy conclusions are listed below:

(1) Western academia, mainly from the United States and Western European countries, dominates this domain, with the recent emergence of non-Western academics.

(2) The research subject is relatively interdisciplinary, with the disciplines "Economic and Political Science" and "Ecology, Earth, and Marine" being the most common, where expertise from "Economic and Political Science" is usually mixed with specific knowledge.

(3) Research of the Resource Curse/Dutch Disease/Conflict resource domain has advanced exponentially, principally since the early 2000s.

(4) Resources Policy, Extractive Industries and Society-an International Journal, and World Development, are the most impactful journals in the field, indicating that the Resource Curse/Dutch Disease/Conflict resource literature does not belong to a single empirical field.

(5) Dutch Disease mainly originates from the woes of the Dutch economy in the 1970s described by The Economist [28]. In 1993, the "Resource Curse" was first adopted by Richard Auty to explain states with abundant mineral reserves could not utilize their advancement to incite economic prosperity and, counterintuitively, had weaker economic development than countries with fewer natural resources [18]. Most research clusters focused on economic or social-political problems, such as conflict minerals in addition to fragile state models or hypotheses. All the clusters were very disjointed, advocating that knowledge transfer across major domains is restricted, which represents a potential path for future research.

These findings are beneficial for new scholars unfamiliar with the academic field of Resource Curse/Dutch Disease/Conflict resource research. This study sheds light on this research domain's formation and dynamics, as well as helps formulate several future research avenues. This review may also help veteran scholars explore the increasingly expanding research field, whether for teaching or science. The results can also help journal editors figure out how their journal integrates with the broader academic research endeavor or recognize hotspots, such as deciding whether to design a particular journal's theme dedicated to a single subject.

According to the initial attempt to use the bibliometric review to compare the literature on easily misunderstood terminologies, despite the literature on "Resource Curse" and "Dutch Disease" emerging first with a grander range, research on "Conflict resource" is catching up quickly. Notwithstanding the convergence between prestigious journals and keywords, each of the three literature strings has a distinct emphasis.

When contrasting the three strings of literature regarding co-authorship, Resource Curse research was shown to have the largest numbers of papers and the maximum 
citations. Many authors/institutes/countries predominate the three literature strings. This study sheds new light on the background and interrelationships of those terms. It shows the superiority of scientometric methods and the ease with which they may equate similarly related parts of literature.

Funding: This research received no external funding.

Institutional Review Board Statement: Not applicable.

Data Availability Statement: Data is provided in Tables A1-A7.

Conflicts of Interest: The author declares no conflict of interest.

\section{Appendix A}

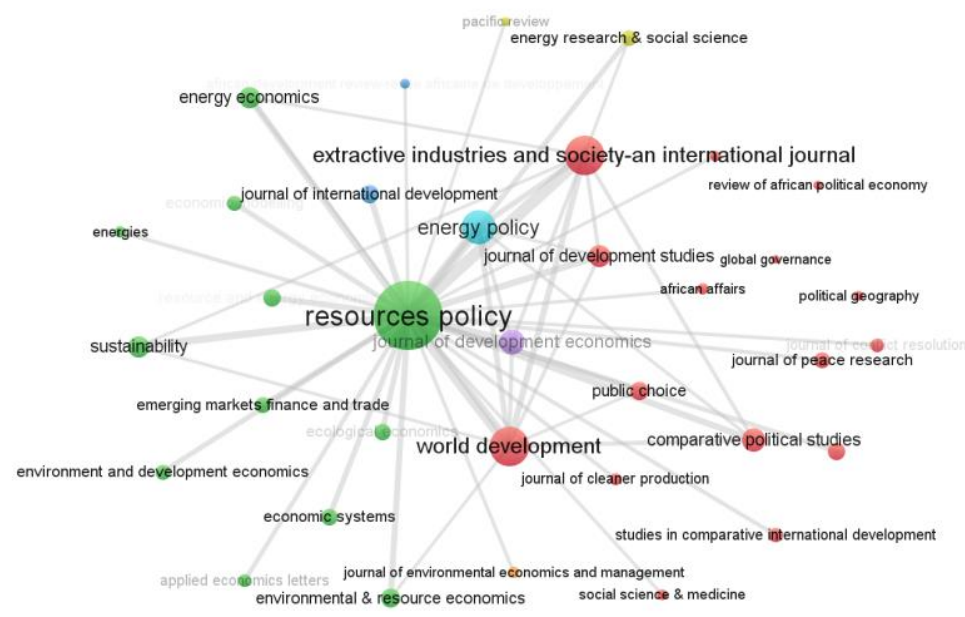

Figure A1. Network of prominent journals on the resource curse.

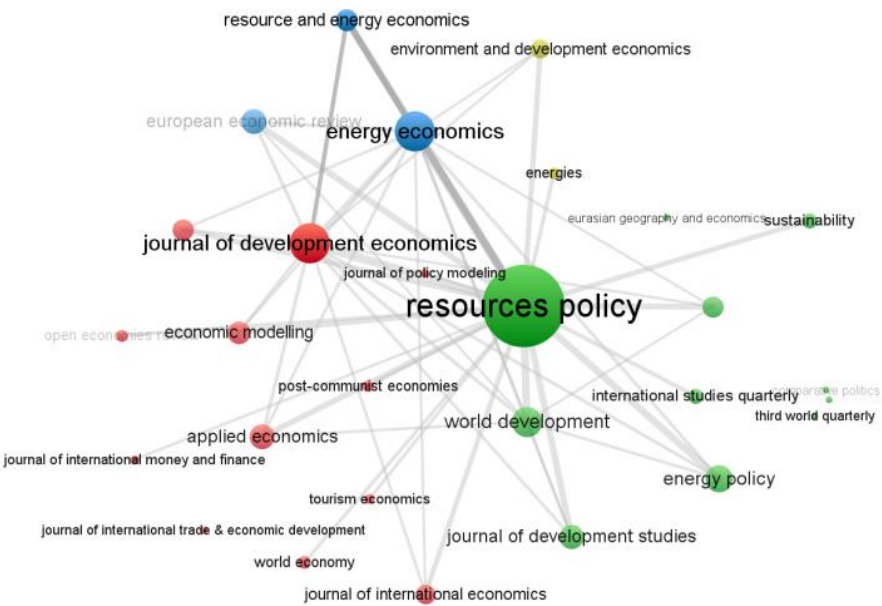

Figure A2. Network of prominent journals on Dutch disease. 


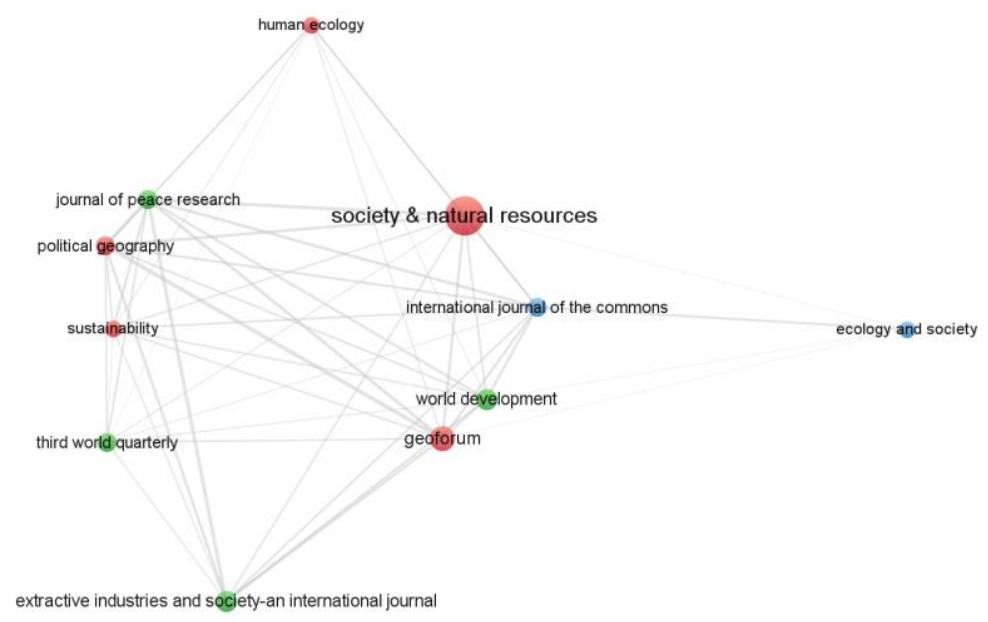

Figure A3. Network of prominent journals on resource conflict.

Table A1. Mainstream journals converging in the three strings of literature.

\begin{tabular}{|c|c|c|c|}
\hline $\begin{array}{l}\text { Resource Curse and Dutch } \\
\text { Disease }\end{array}$ & $\begin{array}{l}\text { Resource Curse and } \\
\text { Resource Conflict }\end{array}$ & $\begin{array}{l}\text { Dutch Disease and } \\
\text { Resource Conflict }\end{array}$ & All Three \\
\hline $\begin{array}{l}\text { Economic Modelling; Energies; } \\
\text { Energy Economics; Energy } \\
\text { Policy; Environment and } \\
\text { Development Economics; } \\
\text { Extractive Industries and } \\
\text { Society; International Studies } \\
\text { Quarterly; Journal of } \\
\text { Development Economics; } \\
\text { Journal of Development } \\
\text { Studies; Resource and Energy } \\
\text { Economics; Resources Policy; } \\
\text { Sustainability; Third World } \\
\text { Quarterly; World } \\
\text { Development }\end{array}$ & $\begin{array}{c}\text { Journal of Peace } \\
\text { Research; Political } \\
\text { Geography }\end{array}$ & $\begin{array}{l}\text { Extractive Industries } \\
\text { and Society; } \\
\text { Sustainability; Third } \\
\text { World Quarterly; } \\
\text { World Development }\end{array}$ & $\begin{array}{l}\text { Emerging Markets } \\
\text { Finance and Trade; } \\
\text { Journal of } \\
\text { International Money } \\
\text { and Finance; Applied } \\
\text { Economics; Energy } \\
\text { Policy; Resources } \\
\text { Policy; Sustainability }\end{array}$ \\
\hline
\end{tabular}

Table A2. Keywords purely from one string of the literature.

\begin{tabular}{ccc}
\hline Resource Curse Only & Dutch Disease Only & Resource Conflict Only \\
\hline $\begin{array}{c}\text { authoritarianism; world; transparency; } \\
\text { government; globalization; boom; }\end{array}$ & & \\
taxation; sustainable development; & & \\
Ghana; geography; civil conflict; & & \\
survival; sub-Saharan Africa; foreign & aid; shocks; rentier state; & community; conflict diamonds; \\
direct investment; civil war; rents; & exchange rate; foreign aid; & $\begin{array}{c}\text { conservation; management; } \\
\text { natural resource conflict; } \\
\text { puality; political economy; extractive }\end{array}$ \\
industries; democratization; & remittances; foreign-aid; ecology; resource \\
performance; origins; extraction; & $\begin{array}{c}\text { industrialization; real exchange } \\
\text { conflict; resource conflicts; }\end{array}$ & \\
determinants; natural resource curse; & rate exchange-rate; & \\
models; development; mining; & & \\
institutional quality; diamonds; & & \\
impacts; hypothesis; economic & & \\
development; & & \\
\hline
\end{tabular}


Table A3. Cluster 1 high-impact members.

\begin{tabular}{|c|c|c|c|c|c|c|c|c|}
\hline Rank & Freq & Burst & Degree & Author & Year & Source & Half-Life & ID \\
\hline 1 & 53 & 28.2 & 5 & Ross M & 2012 & $\begin{array}{c}\text { The Oil Curse: How } \\
\text { Petroleum Wealth Shapes } \\
\text { the Development of } \\
\text { Nations }\end{array}$ & 3.5 & 1 \\
\hline 2 & 49 & 27.4 & 12 & Haber S & 2011 & $\begin{array}{c}\text { American Political Science } \\
\text { Review }\end{array}$ & 3.5 & 1 \\
\hline 3 & 38 & 19.1 & 10 & Alexeev M & 2009 & $\begin{array}{l}\text { The Review of Economics } \\
\text { and Statistics }\end{array}$ & 3.5 & 1 \\
\hline 4 & 32 & 15.3 & 14 & Andersen JJ & 2014 & $\begin{array}{c}\text { Comparative Political } \\
\text { Studies }\end{array}$ & 2.5 & 1 \\
\hline 5 & 29 & 14.1 & 23 & Cotet AM & 2013 & $\begin{array}{l}\text { American Economic } \\
\text { Journal: Macroeconomics }\end{array}$ & 2.5 & 1 \\
\hline 6 & 24 & 12 & 4 & Dunning $\mathrm{T}$ & 2008 & $\begin{array}{l}\text { Crude democracy: } \\
\text { Natural resource wealth } \\
\text { and political regimes }\end{array}$ & 3.5 & 1 \\
\hline 7 & 24 & 10.4 & 13 & Wright J & 2015 & $\begin{array}{l}\text { British Journal of Political } \\
\text { Science }\end{array}$ & 2.5 & 1 \\
\hline 8 & 19 & 11.4 & 16 & van der Ploeg F & 2010 & $\begin{array}{l}\text { Journal of Environmental } \\
\text { Economics and } \\
\text { Management }\end{array}$ & 3.5 & 1 \\
\hline 9 & 18 & 10.2 & 11 & Bhattacharyya S & 2010 & $\begin{array}{l}\text { European Economic } \\
\text { Review }\end{array}$ & 3.5 & 1 \\
\hline 10 & 18 & 8.78 & 15 & Morrison KM & 2009 & International Organization & 3.5 & 1 \\
\hline
\end{tabular}

Table A4. Citing articles in Cluster 1.

\begin{tabular}{|c|c|c|c|c|c|}
\hline Rank & Coverage & GCS & Author & Time & Title \\
\hline 1 & 30 & 196 & Ross, Michael L & 2015 & $\begin{array}{c}\text { What have we learned about the } \\
\text { resource curse? }\end{array}$ \\
\hline 2 & 17 & 11 & Boos, Adrian & 2012 & $\begin{array}{l}\text { A theoretical overview of the } \\
\text { relationship between the resource } \\
\text { curse and genuine savings as an } \\
\text { indicator for "weak" sustainability }\end{array}$ \\
\hline 3 & 17 & 68 & Koubi, Vally & 2014 & $\begin{array}{l}\text { Do natural resources matter for } \\
\text { interstate and intrastate armed } \\
\text { conflict? }\end{array}$ \\
\hline 4 & 15 & 12 & Wiens, David & 2014 & $\begin{array}{c}\text { Natural resources and institutional } \\
\text { development }\end{array}$ \\
\hline 5 & 15 & 12 & $\begin{array}{l}\text { Venables, } \\
\text { Anthony J }\end{array}$ & 2010 & $\begin{array}{l}\text { Resource rents: when to spend and } \\
\text { how to save }\end{array}$ \\
\hline 6 & 14 & 27 & Blanco, Luisa & 2012 & $\begin{array}{l}\text { Natural resource dependence and } \\
\text { the accumulation of physical and } \\
\text { human capital in Latin America }\end{array}$ \\
\hline 7 & 12 & 12 & $\begin{array}{l}\text { Morrison, Kevin } \\
\mathrm{M}\end{array}$ & 2013 & Whither the resource curse? \\
\hline 8 & 12 & 19 & Tsui, Kevin K & 2010 & $\begin{array}{l}\text { Resource curse, political entry, and } \\
\text { deadweight costs }\end{array}$ \\
\hline 9 & 11 & 9 & Ansari, Dawud & 2016 & $\begin{array}{l}\text { Resource curse contagion in the } \\
\text { case of Yemen }\end{array}$ \\
\hline 10 & 10 & 606 & $\begin{array}{l}\text { van der Ploeg, } \\
\text { Frederick }\end{array}$ & 2011 & $\begin{array}{l}\text { Natural resources: curse or } \\
\text { blessing? }\end{array}$ \\
\hline
\end{tabular}


Table A5. Cluster 5 high-impact members.

\begin{tabular}{|c|c|c|c|c|c|c|c|c|}
\hline Rank & Freq & Burst & Degree & Author & Year & Source & Half-Life & ID \\
\hline 1 & 81 & 46 & 4 & van der Ploeg F & 2011 & $\begin{array}{l}\text { Journal of Economic } \\
\text { Literature }\end{array}$ & 3.5 & 5 \\
\hline 2 & 31 & 16 & 6 & Van Der Ploeg F & 2017 & $\begin{array}{c}\text { Journal of Development } \\
\text { Studies }\end{array}$ & 2.5 & 5 \\
\hline 3 & 30 & 14 & 3 & Smith B & 2015 & $\begin{array}{c}\text { Journal of Development } \\
\text { Economics }\end{array}$ & 3.5 & 5 \\
\hline 4 & 29 & 13 & 10 & James A & 2015 & $\begin{array}{c}\text { Journal of Development } \\
\text { Economics }\end{array}$ & 3.5 & 5 \\
\hline 5 & 29 & 14 & 3 & Venables AJ & 2016 & $\begin{array}{l}\text { Journal of Economic } \\
\text { Perspectives }\end{array}$ & 2.5 & 5 \\
\hline 6 & 26 & 14 & 15 & Caselli F & 2013 & $\begin{array}{l}\text { American Economic } \\
\text { Journal: Applied } \\
\text { Economics }\end{array}$ & 2.5 & 5 \\
\hline 7 & 21 & 10 & 4 & Cockx L & 2016 & Energy Policy & 2.5 & 5 \\
\hline 8 & 20 & 9.1 & 8 & Betz MR & 2015 & Energy Economics & 3.5 & 5 \\
\hline 9 & 20 & 11 & 3 & Papyrakis E & 2017 & $\begin{array}{l}\text { Journal of Development } \\
\text { Studies }\end{array}$ & 2.5 & 5 \\
\hline 10 & 20 & 9.9 & 12 & Cust J & 2015 & $\begin{array}{l}\text { Annual Review of } \\
\text { Resource Economics }\end{array}$ & 3.5 & 5 \\
\hline
\end{tabular}

Table A6. Citing articles in Cluster 5.

\begin{tabular}{|c|c|c|c|c|c|}
\hline Rank & Coverage & GCS & Author & Time & Title \\
\hline 1 & 15 & 115 & $\begin{array}{l}\text { Badeeb, Ramez } \\
\text { Abubakr }\end{array}$ & 2017 & $\begin{array}{l}\text { The evolution of the natural } \\
\text { resource curse thesis: a critical } \\
\text { literature survey }\end{array}$ \\
\hline 2 & 13 & 38 & Fleming, David A & 2015 & $\begin{array}{l}\text { Understanding the resource curse } \\
\text { (or blessing) across national and } \\
\text { regional scales: theory, empirical } \\
\text { challenges and an application }\end{array}$ \\
\hline 3 & 12 & 6 & Morck, Randall & 2018 & $\begin{array}{l}\text { Japan's ultimately unaccursed } \\
\text { natural resources-financed } \\
\text { industrialization }\end{array}$ \\
\hline 4 & 11 & 41 & Cust, James & 2015 & $\begin{array}{l}\text { The local economic impacts of } \\
\text { natural resource extraction }\end{array}$ \\
\hline 5 & 11 & 16 & Mayer, Adam & 2018 & $\begin{array}{l}\text { Fracking fortunes: economic } \\
\text { well-being and oil and gas } \\
\text { development along the urban-rural } \\
\text { continuum }\end{array}$ \\
\hline 6 & 10 & 36 & $\begin{array}{c}\text { Komarek, Timothy } \\
\text { M }\end{array}$ & 2016 & $\begin{array}{l}\text { Labor market dynamics and the } \\
\text { unconventional natural gas boom: } \\
\text { evidence from the Marcellus region }\end{array}$ \\
\hline 7 & 10 & 20 & Kelsey, Timothy W & 2016 & $\begin{array}{l}\text { Unconventional gas and oil } \\
\text { development in the united states: } \\
\text { economic experience and policy } \\
\text { issues }\end{array}$ \\
\hline 8 & 10 & 1 & Bildirici, Melike E & 2020 & $\begin{array}{l}\text { Precious metal abundance and } \\
\text { economic growth: evidence from } \\
\text { top precious metal producer } \\
\text { countries }\end{array}$ \\
\hline 9 & 10 & 9 & Miljkovic, Dragan & 2016 & $\begin{array}{c}\text { Labor market impacts of us tight oil } \\
\text { development: the case of the } \\
\text { Bakken }\end{array}$ \\
\hline 10 & 10 & 4 & Hilmawan, Rian & 2019 & $\begin{array}{l}\text { An investigation of the resource } \\
\text { curse in Indonesia }\end{array}$ \\
\hline
\end{tabular}


Table A7. Cluster 7 high-impact members.

\begin{tabular}{ccccccccc}
\hline Rank & Freq & Burst & Degree & Author & Year & Source & Half-Life & ID \\
\hline 1 & 38 & 15 & 6 & Robinson JA & 2006 & Journal of Development & 3.5 & 7 \\
2 & 27 & 9.5 & 1 & Bulte EH & 2005 & World Development & 2.5 & 7 \\
3 & 15 & 5.9 & 2 & Papyrakis E & 2004 & Journal of Comparative & 3.5 & 7 \\
4 & 15 & 5.6 & 2 & Stijns JPC & 2005 & Resources Policy & 2.5 & 7 \\
5 & 11 & 5 & 7 & Ding N & 2005 & Land Economics & 3.5 & 7 \\
6 & 9 & 4 & 8 & Atkinson G & 2003 & World Development & 4.5 & 7 \\
7 & 8 & 3.7 & 8 & Neumayer E & 2004 & World Development & 3.5 & 7 \\
8 & 8 & 3.7 & 9 & Wright G & 2004 & World Development & 1.5 & 7 \\
\hline
\end{tabular}

Table A8. Citing articles in Cluster 7.

\begin{tabular}{|c|c|c|c|c|c|}
\hline Rank & Coverage & GCS & Author & Time & Title \\
\hline 1 & 53 & 74 & Ewers, Robert M & 2006 & $\begin{array}{l}\text { Interaction effects between } \\
\text { economic development and forest } \\
\text { cover determine deforestation rates }\end{array}$ \\
\hline 2 & 23 & 44 & Wick, Katharina & 2009 & The curse of natural resources \\
\hline 3 & 19 & 202 & Papyrakis, Elissaios & 2007 & $\begin{array}{l}\text { Resource abundance and economic } \\
\text { growth in the united states }\end{array}$ \\
\hline 4 & 15 & 127 & Le Billon, Philippe & 2008 & $\begin{array}{l}\text { Diamond wars? conflict diamonds } \\
\text { and geographies of resource war }\end{array}$ \\
\hline 5 & 12 & 346 & $\begin{array}{l}\text { Brunnschweiler, } \\
\text { Christa N }\end{array}$ & 2008 & $\begin{array}{c}\text { The resource curse revisited and } \\
\text { revised: a tale of paradoxes and red } \\
\text { herrings }\end{array}$ \\
\hline 6 & 11 & 108 & Kolstad, Ivar & 2009 & $\begin{array}{l}\text { Corruption in natural resource } \\
\text { management: implications for } \\
\text { policy makers }\end{array}$ \\
\hline 7 & 11 & 207 & $\begin{array}{l}\text { Brunnschweiler, } \\
\text { Christa N }\end{array}$ & 2008 & $\begin{array}{l}\text { Cursing the blessings? natural } \\
\text { resource abundance, institutions, } \\
\text { and economic growth }\end{array}$ \\
\hline 8 & 8 & 41 & Barbier, EB & 2004 & $\begin{array}{l}\text { Agricultural, expansion, resource } \\
\text { booms and growth in Latin } \\
\text { America: implications for economic } \\
\text { development }\end{array}$ \\
\hline 9 & 5 & 22 & Butkiewicz, James L & 2010 & $\begin{array}{l}\text { institutions, openness, and growth: } \\
\text { an empirical analysis }\end{array}$ \\
\hline 10 & 4 & 20 & Sovacool, Benjamin K & 2010 & $\begin{array}{c}\text { The political economy of oil and gas } \\
\text { in southeast Asia: heading toward } \\
\text { the natural resource curse? }\end{array}$ \\
\hline
\end{tabular}

\section{References}

1. Guan, J.; Kirikkaleli, D.; Bibi, A.; Zhang, W. Natural resources rents nexus with financial development in the presence of globalization: Is the "resource curse" exist or myth? Resour. Policy 2020, 66, 101641. [CrossRef]

2. Leite, C.; Weidmann, J. Does Mother Nature Corrupt: Natural Resources, Corruption, and Economic Growth. IMF Work. Pap. 1999, 99, 1. [CrossRef]

3. Sachs, J.D.; Warner, A.M. The curse of natural resources. Eur. Econ. Rev. 2001, 45, 827-838. [CrossRef]

4. Stijns, J.-P.C. Natural resource abundance and economic growth revisited. Resour. Policy 2005, 30, 107-130. [CrossRef]

5. Van der Ploeg, F. Natural resources: Curse or blessing? J. Econ. Lit. 2011, 49, 366-420. [CrossRef]

6. Lashitew, A.; Werker, E. Are Natural Resources a Curse, a Blessing, or a Double-Edged Sword? Brookings. 2020. Available online: https: / / www.brookings.edu/blog/future-development/2020/07/16/are-natural-resources-a-curse-a-blessing-or-adouble-edged-sword/ (accessed on 26 March 2021).

7. Collins, D.; Morduch, J.; Rutherford, S.; Ruthven, O. Portfolios of the Poor: How the World's Poor Live on \$2 A Day; Princeton University Press: Princeton, NJ, USA, 2009.

8. Sachs, J.; McArthur, J.W.; Schmidt-Traub, G.; Kruk, M.; Bahadur, C.; Faye, M.; McCord, G. Ending Africa's poverty trap. Brook. Pap. Econ. Act. 2004, 2004, 117-240. [CrossRef] 
9. Page, J. Strategies for pro-Poor growth: Pro-Poor, pro-growth or Both? J. Afr. Econ. 2006, 15, 510-516, 518-522, 524-535, 537-542. [CrossRef]

10. Arieff, I. If Africa Is So Rich, Why Is It So Poor? PassBlue 2015. Available online: https:/ www.passblue.com/2015/05/18/ifafrica-is-so-rich-why-is-it-so-poor/ (accessed on 3 March 2021).

11. Ayelazuno, J. Oil wealth and the well-being of the subaltern classes in Sub-Saharan Africa: A critical analysis of the resource curse in Ghana. Resour. Policy 2014, 40, 66-73. [CrossRef]

12. Gupta, S.; Pattillo, C.A.; Wagh, S. Effect of Remittances on Poverty and Financial Development in Sub-Saharan Africa. World Dev. 2009, 37, 104-115. [CrossRef]

13. McGee, J.A.; Greiner, P.T. Renewable energy injustice: The socio-environmental implications of renewable energy consumption Energy Res. Soc. Sci. 2019, 56, 101214. [CrossRef]

14. Odedra, M.; Bennett, M.; Goodman, S.; Lawrie, M. Sub-Saharan Africa: A technological desert. Commun. ACM 1993, 36, 25-29. [CrossRef]

15. Rowley, C.K. Political culture and economic performance in sub-Saharan Africa. In Public Choice Essays in Honor of a Maverick Scholar: Gordon Tullock; Fishback, P.V., Libecap, G.D., Zajac, E., Eds.; Springer: New York, NY, USA, 2000; pp. $29-51$.

16. Langan, M. Neo-Colonialism and the Poverty of'Development'in Africa; Palgrave Macmillan: Basingstoke, Hampshire, 2017.

17. An, Z.; Shen, Z.; Zhou, J.; Wu, J.; Fan, Y.; Wang, Y.; Stanley, H.E. The science of science: From the perspective of complex systems. Phys. Rep. 2017, 714, 1-73.

18. Auty, R.; Warhurst, A. Sustainable development in mineral exporting economies. Resour. Policy 1993, 19, 14-29. [CrossRef]

19. Mittelman, M. The Resource Curse. Bloomberg. 2014. Available online: https://www.bloomberg.com/quicktake/resource-curse (accessed on 2 April 2021).

20. Shaxson, N. Oil, corruption and the resource curse. Int. Aff. 2007, 83, 1123-1140. [CrossRef]

21. Myint, U. Corruption: Causes, consequences and cures. Asia Pac. Dev. J. 2020, 7, 33-58.

22. Fernando, J. Resource Curse. Investopedia. 2011. Available online: https://www.investopedia.com/terms/r/resource-curse.asp (accessed on 2 April 2021).

23. Neumayer, E. Does the "resource curse" hold for growth in genuine income as well? World Dev. 2004, 32, 1627-1640. [CrossRef]

24. Sandbu, M.E. Natural wealth accounts: A proposal for alleviating the natural resource curse. World Dev. 2006, 34, 1153-1170. [CrossRef]

25. Sierra Leone Telegraph. Is Sierra Leone Richly Poor or Poorly Rich? 2021. Available online: https:/ /www.thesierraleonetelegraph. com/is-sierra-leone-richly-poor-or-poorly-rich/ (accessed on 3 May 2021).

26. Sachs, J.D.; Warner, A.M. Natural resource abundance and economic growth. Natl. Bur. Econ. Res. 1995. Available online: https: / / www.proquest.com/reports/natural-resource-abundance-economic-growth/docview/1820715529/se-2?accountid=14426 (accessed on 2 April 2021).

27. Ianchovichina, E.; Onder, H. Dutch Disease: An Economic Illness Easy to Catch, Difficult to Cure. Brookings. 2017. Available online: https: / www.brookings.edu/blog/future-development/2017/10/31/dutch-disease-an-economic-illness-easy-to-catchdifficult-to-cure/ (accessed on 2 April 2021).

28. The Economist. What Dutch Disease Is, and Why It's Bad. 2021. Available online: https:/ /www.economist.com/the-economistexplains /2014/11/05/what-dutch-disease-is-and-why-its-bad (accessed on 2 April 2021).

29. Behzadan, N.; Chisik, R.; Onder, H.; Battaile, B. Does inequality drive the Dutch disease? Theory and evidence. J. Int. Econ. 2017, 106, 104-118. [CrossRef]

30. Larsen, E.R. Escaping the resource curse and the Dutch disease? When and why Norway caught up with and forged ahead of its neighbors. Am. J. Econ. Sociol. 2006, 65, 605-640. [CrossRef]

31. Atkinson, G.; Hamilton, K. Savings, Growth and the Resource Curse Hypothesis. World Dev. 2003, 31, 1793-1807. [CrossRef]

32. Frankel, J. The Natural Resource Curse. In Beyond the Resource Curse; Shaffer, B., Ziyadov, T., Eds.; University of Pennsylvania Press: Philadelphia, PA, USA, 2010; pp. 17-57.

33. Mehlum, H.; Moene, K.O.; Torvik, R. Institutions and the Resource Curse. Econ. J. 2006, 116, 1-20. [CrossRef]

34. Paul, S. Resource impact: Curse or blessing? A literature survey. J. Energy Lit. 2003, 9, 3-42.

35. Gershoni, Y. War without End and an End to a War: The Prolonged Wars in Liberia and Sierra Leone. Afr. Stud. Rev. 1997, 40, 55. [CrossRef]

36. Nagel, J.; Whorton, B. Ethnic conflict and the world system: International competition in Iraq (1961-1991) and Angola (1974-1991) J. Political Mil. Sociol. 1992, 20, 1-35.

37. Howe, H. Lessons of Liberia: ECOMOG and regional peacekeeping. Int. Secur. 1996, 21, 145-176. [CrossRef]

38. Le Billon, P. Power is Consuming the Forest: The Political Ecology of Conflict and Reconstruction in Cambodia; University of Oxford: Oxford, UK, 1999.

39. Earthworks, Conflict Minerals-Earthworks. 2018. Available online: https://www.earthworks.org/issues/conflict_minerals/ (accessed on 2 April 2021).

40. Global Witness, Conflict Resources Undermine Peacebuilding as War in Congo Looms. 2021. Available online: https:/ /www. globalwitness.org/en/archive/conflict-resources-undermine-peacebuilding-war-congo-looms/ (accessed on 2 April 2021).

41. Grant, J.A. The Kimberley Process at Ten: Reflections on a Decade of Efforts to End the Trade in Conflict Diamonds. In The Global Diamond Industry; Springer Science and Business Media LLC: London, UK, 2012; pp. 119-142. 
42. Howard, A. Blood Diamonds: The Successes and Failures of the Kimberley Process Certification Scheme in Agnola, Sierra Leone and Zimbabwe. Wash. U. Glob. Stud. L. Rev. 2016, 15, 137.

43. Le Billon, P. Diamond wars? Conflict diamonds and geographies of resource wars. Ann. Assoc. Am. Geogr. 2008, 98, 345-372. [CrossRef]

44. Wick, K.; Bulte, E.H. Contesting resources-Rent seeking, conflict and the natural resource curse. Public Choice 2006, 128, 457-476. [CrossRef]

45. Andrews-Speed, P.; Bleischwitz, R.; Boersma, T.; Johnson, C.; Kemp, G.; VanDeveer, S.D. The Global Resource Nexus: The Struggles for Land, Energy, Food, Water, and Minerals; Taylor \& Francis Group: London, UK, 2014.

46. Chen, C. Science Mapping: A Systematic Review of the Literature. J. Data Inf. Sci. 2017, 2, 1-40. [CrossRef]

47. Powell, T.H.; Kouropalatis, Y.; Morgan, R.E.; Karhu, P. Mapping knowledge and innovation research themes: Using bibliometrics for classification, evolution, proliferation and determinism. Int. J. Entrep. Innov. Manag. 2016, 20, 174-199. [CrossRef]

48. What Is Social Network Analysis? Available online: https:/ / www.insna.org/ (accessed on 23 July 2021).

49. Ware, M.; Mabe, M. The STM Report: An Overview of Scientific and Scholarly Journal Publishing; International Association of Scientific, Technical and Medical Publishers: Hague, The Netherlands, 2015.

50. Yi, Y.; Luo, J.; Wübbenhorst, M. Research on political instability, uncertainty and risk during 1953-2019: A scientometric review. Science 2020, 123, 1051-1076. [CrossRef]

51. Jiang, W.; Martek, I.; Hosseini, M.R.; Chen, C. Political risk management of foreign direct investment in infrastructure projects. Eng. Constr. Arch. Manag. 2019, 28, 125-153. [CrossRef]

52. Reale, E.; Avramov, D.; Canhial, K.; Donovan, C.; Flecha, R.; Holm, P.; Larkin, C.; Lepori, B.; Mosoni-Fried, J.; Oliver, E.; et al. A review of literature on evaluating the scientific, social and political impact of social sciences and humanities research. Res. Eval. 2018, 27, 298-308. [CrossRef]

53. Bin, C.; Weiqi, C.; Shaoling, C.; Chunxia, H. Visual Analysis of Research Hot Spots, Characteristics, and Dynamic Evolution of International Competitive Basketball Based on Knowledge Mapping. SAGE Open 2021, 11. [CrossRef]

54. Caputo, A.; Pizzi, S.; Pellegrini, M.M.; Dabić, M. Digitalization and business models: Where are we going? A science map of the field. J. Bus. Res. 2021, 123, 489-501. [CrossRef]

55. Celik, E.; Durmus, A.; Adizel, O.; Uyar, H.N. A bibliometric analysis: What do we know about metals(loids) accumulation in wild birds? Environ. Sci. Pollut. Res. 2021, 28, 10302-10334. [CrossRef]

56. Chen, C.; Li, C.; Reniers, G.; Yang, F. Safety and security of oil and gas pipeline transportation: A systematic analysis of research trends and future needs using WoS. J. Clean. Prod. 2021, 279, 123583. [CrossRef]

57. Chen, S.; Lin, N. Culture, productivity and competitiveness: Disentangling the concepts. Cross Cult. Strat. Manag. 2020, 28, 52-75. [CrossRef]

58. Chen, R.; Zhang, R.; Han, H. Where has carbon footprint research gone? Ecol. Indic. 2021, 120, 106882. [CrossRef]

59. Dardonville, M.; Bockstaller, C.; Therond, O. Review of quantitative evaluations of the resilience, vulnerability, robustness and adaptive capacity of temperate agricultural systems. J. Clean. Prod. 2021, 286, 125456. [CrossRef]

60. Donthu, N.; Kumar, S.; Pandey, N. A retrospective evaluation of Marketing Intelligence and Planning: 1983-2019. Mark. Intell. Plan. 2020, 39, 48-73. [CrossRef]

61. Feng, Y.; Cui, S. A review of emergency response in disasters: Present and future perspectives. Nat. Hazards 2021, 105, 1109-1138 [CrossRef]

62. Ferreira, F.A.F.; Santos, S.P. Two decades on the MACBETH approach: A bibliometric analysis. Ann. Oper. Res. 2021, 296, 901-925. [CrossRef]

63. Fu, J.; Jiang, Z.; Hong, Y.; Liu, S.; Kong, D.; Zhong, Z.; Luo, Y. Global scientific research on social participation of older people from 2000 to 2019: A bibliometric analysis. Int. J. Older People Nurs. 2021, 16. [CrossRef] [PubMed]

64. Gao, J.; Wu, X.; Luo, X.; Guan, S. Scientometric Analysis of Safety Sign Research: 1990-2019. Int. J. Environ. Res. Public Health 2021, 18, 273. [CrossRef]

65. Goksu, I. Bibliometric mapping of mobile learning. Telemat. Inform. 2021, 56, 101491. [CrossRef]

66. Guan, G.; Jiang, Z.; Gong, Y.; Huang, Z.; Jamalnia, A. A Bibliometric Review of Two Decades' Research on Closed-Loop Supply Chain: 2001-2020. IEEE Access 2021, 9, 3679-3695. [CrossRef]

67. Guo, Y.-M.; Huang, Z.-L.; Guo, J.; Guo, X.-R.; Li, H.; Liu, M.-Y.; Ezzeddine, S.; Nkeli, M.J. A bibliometric analysis and visualization of blockchain. Futur. Gener. Comput. Syst. 2021, 116, 316-332. [CrossRef]

68. Flórez-Martínez, D.H.; Contreras-Pedraza, C.A.; Rodríguez, J. A systematic analysis of non-centrifugal sugar cane processing: Research and new trends. Trends Food Sci. Technol. 2021, 107, 415-428. [CrossRef]

69. Herrera-Franco, G.; Montalván-Burbano, N.; Carrión-Mero, P.; Jaya-Montalvo, M.; Gurumendi-Noriega, M. Worldwide Research on Geoparks through Bibliometric Analysis. Sustainability 2021, 13, 1175. [CrossRef]

70. Hou, L.; Chen, H.; Zhang, G.K.; Wang, X. Deep Learning-Based Applications for Safety Management in the AEC Industry: A Review. Appl. Sci. 2021, 11, 821. [CrossRef]

71. Hou, L.-X.; Liu, R.; Liu, H.-C.; Jiang, S. Two decades on human reliability analysis: A bibliometric analysis and literature review. Ann. Nucl. Energy 2021, 151, 107969. [CrossRef]

72. Hui, J.; Wang, L.; Liu, R.; Yang, C.; Zhang, H.; He, S.; Chen, Z.; Wei, A. A bibliometric analysis of international publication trends in premature ejaculation research (2008-2018). Int. J. Impot. Res. 2021, 33, 86-95. [CrossRef] [PubMed] 
73. Kolstad, I.; Wiig, A. What determines Chinese outward FDI? J. World Bus. 2012, 47, 26-34. [CrossRef]

74. Blondel, V.D.; Guillaume, J.-L.; Lambiotte, R.; Lefebvre, E. Fast unfolding of communities in large networks. J. Stat. Mech. Theory Exp. 2008, 10, P10008. [CrossRef]

75. Chen, C. CiteSpace II: Detecting and visualizing emerging trends and transient patterns in scientific literature. J. Am. Soc. Inf. Sci. Technol. 2006, 57, 359-377. [CrossRef]

76. Carley, S.; Porter, A.L.; Rafols, I.; Leydesdorff, L. Visualization of disciplinary profiles: Enhanced science overlay maps. J. Data Inf. Sci. 2017, 2, 68-111. [CrossRef]

77. Kim, M.C.; Zhu, Y.; Chen, C. How are they different? A quantitative domain comparison of information visualization and data visualization (2000-2014). Science 2016, 107, 123-165. [CrossRef]

78. Nasir, A.; Shaukat, K.; Hameed, I.A.; Luo, S.; Mahboob, T.; Iqbal, F. A Bibliometric Analysis of Corona Pandemic in Social Sciences: A Review of Influential Aspects and Conceptual Structure. IEEE Access 2020, 8, 133377-133402. [CrossRef]

79. World Development The Multi-Disciplinary International Journal Devoted to the Study and Promotion of World Development, Elsevier. 2021. Available online: https:/ / www.journals.elsevier.com/world-development (accessed on 19 July 2021).

80. Van Eck, N.J.; Waltman, L. VOSviewer manual. Leiden Univ. Leiden 2013, 1, 1-53.

81. Li, H.; An, H.; Wang, Y.; Huang, J.; Gao, X. Evolutionary features of academic articles co-keyword network and keywords co-occurrence network: Based on two-mode affiliation network. Phys. A Stat. Mech. Its Appl. 2016, 450, 657-669. [CrossRef]

82. Pinto, M.; Pulgarín, A.; Escalona, M.I. Viewing information literacy concepts: A comparison of two branches of knowledge. Scientometrics 2014, 98, 2311-2329. [CrossRef]

83. Jin, Y.; Ji, S.; Li, X.; Yu, J. A scientometric review of hotspots and emerging trends in additive manufacturing. J. Manuf. Technol. Manag. 2017, 28, 18-38. [CrossRef]

84. Li, X.; Qiao, H.; Wang, S. Exploring evolution and emerging trends in business model study: A co-citation analysis. Science 2017, 111, 869-887. [CrossRef]

85. Williams, A. Shining a Light on the Resource Curse: An Empirical Analysis of the Relationship Between Natural Resources, Transparency, and Economic Growth. World Dev. 2011, 39, 490-505. [CrossRef]

86. Boyce, J.R.; Emery, J.H.C. Is a negative correlation between resource abundance and growth sufficient evidence that there is a "resource curse"? Resour. Policy 2011, 36, 1-13. [CrossRef]

87. Michaels, G. The Long Term Consequences of Resource-Based Specialisation. Econ. J. 2010, 121, 31-57. [CrossRef]

88. Beine, M.; Bos, C.; Coulombe, S. Does the Canadian economy suffer from Dutch disease? Resour. Energy Econ. 2012, 34, 468-492. [CrossRef]

89. Weber, J.G. The effects of a natural gas boom on employment and income in Colorado, Texas, and Wyoming. Energy Econ. 2012, 34, 1580-1588. [CrossRef]

90. Bjorvatn, K.; Farzanegan, M.R.; Schneider, F. Resource Curse and Power Balance: Evidence from Oil-Rich Countries. World Dev. 2012, 40, 1308-1316. [CrossRef]

91. Caselli, F.; Michaels, G. Do Oil Windfalls Improve Living Standards? Evidence from Brazil. Am. Econ. J. Appl. Econ. 2013, 5, 208-238. [CrossRef]

92. Boschini, A.; Pettersson, J.; Roine, J. The Resource Curse and its Potential Reversal. World Dev. 2013, 43, 19-41. [CrossRef]

93. Sala-I-Martin, X.; Subramanian, A. Addressing the Natural Resource Curse: An Illustration from Nigeria. J. Afr. Econ. 2013, 22, 570-615. [CrossRef]

94. Aragón, F.M.; Rud, J.P. Natural resources and local communities: Evidence from a Peruvian gold mine. Am. Econ. J. Econ. Policy 2013, 5, 1-25. [CrossRef]

95. Bhattacharyya, S.; Hodler, R. Do Natural Resource Revenues Hinder Financial Development? The Role of Political Institutions. World Dev. 2014, 57, 101-113. [CrossRef]

96. Shao, S.; Yang, L. Natural resource dependence, human capital accumulation, and economic growth: A combined explanation for the resource curse and the resource blessing. Energy Policy 2014, 74, 632-642. [CrossRef]

97. Weber, J.G. A decade of natural gas development: The makings of a resource curse? Resour. Energy Econ. 2014, 37, 168-183. [CrossRef]

98. James, A. The resource curse: A statistical mirage? J. Dev. Econ. 2015, 114, 55-63. [CrossRef]

99. Fleming, D.A.; Measham, T.G.; Paredes, D. Understanding the resource curse (or blessing) across national and regional scales: Theory, empirical challenges and an application. Aust. J. Agric. Resour. Econ. 2015, 59, 624-639. [CrossRef]

100. Venables, A.J. Using natural resources for development: Why has it proven so difficult? J. Econ. Perspect. 2016, 30, 161-184. [CrossRef]

101. Cockx, L.; Francken, N. Natural resources: A curse on education spending? Energy Policy 2016, 92, 394-408. [CrossRef]

102. Papyrakis, E. The resource curse-what have we learned from two decades of intensive research: Introduction to the special issue. J. Dev. Stud. 2017, 53, 175-185. [CrossRef]

103. Papyrakis, E.; Gerlagh, R. Resource abundance and economic growth in the United States. Eur. Econ. Rev. 2007, 51, 1011-1039. [CrossRef]

104. Van der Ploeg, F.; Poelhekke, S. The pungent smell of "red herrings": Subsoil assets, rents, volatility and the resource curse. J. Environ. Econ. Manag. 2010, 60, 44-55. [CrossRef]

105. Bulte, E.; Damania, R.; Deacon, R.T. Resource intensity, institutions, and development. World Dev. 2005, 33, 1029-1044. [CrossRef] 
106. Isham, J.; Woolcock, M.; Pritchett, L.; Busby, G. The Varieties of Resource Experience: Natural Resource Export Structures and the Political Economy of Economic Growth. World Bank Econ. Rev. 2005, 19, 141-174. [CrossRef]

107. Mehlum, H.; Moene, K.; Torvik, R. Cursed by resources or institutions? World Econ. 2006, 29, 1117-1131. [CrossRef]

108. Robinson, J.A.; Torvik, R.; Verdier, T. Political foundations of the resource curse. J. Dev. Econ. 2006, 79, 447-468. [CrossRef]

109. Hodler, R. The curse of natural resources in fractionalized countries. Eur. Econ. Rev. 2006, 50, 1367-1386. [CrossRef]

110. Boschini, A.D.; Pettersson, J.; Roine, J. Resource curse or not: A question of appropriability. Scand. J. Econ. 2007, 109, 593-617. [CrossRef]

111. Brunnschweiler, C.N. Cursing the Blessings? Natural Resource Abundance, Institutions, and Economic Growth. World Dev. 2008, 36, 399-419. [CrossRef]

112. Dunning, T. Crude Democracy: Natural Resource Wealth and Political Regimes; Cambridge University Press: Cambridge, UK, 2008.

113. Alexeev, M.; Conrad, R. The Elusive Curse of Oil. Rev. Econ. Stat. 2009, 91, 586-598. [CrossRef]

114. Collier, P.; Hoeffler, A. Testing the neocon agenda: Democracy in resource-rich societies. Eur. Econ. Rev. 2009, 53, 293-308. [CrossRef]

115. Kolstad, I.; Wiig, A. Is Transparency the Key to Reducing Corruption in Resource-Rich Countries? World Dev. 2009, 37, 521-532. [CrossRef]

116. James, A.; Aadland, D. The curse of natural resources: An empirical investigation of U.S. counties. Resour. Energy Econ. 2011, 33, 440-453. [CrossRef]

117. Humphreys, M.; Sachs, J.; Stiglitz, J.E. Escaping the Resource Curse; Columbia University Press: New York, NY, USA; Chichester, UK, 2007.

118. Morrison, K.M. Oil, nontax revenue, and the redistributional foundations of regime stability. Int. Organ. 2009, 63, 107-138. [CrossRef]

119. Bhattacharyya, S.; Hodler, R. Natural resources, democracy and corruption. Eur. Econ. Rev. 2010, 54, 608-621. [CrossRef]

120. Aslaksen, S. Oil and democracy: More than a cross-country correlation? J. Peace Res. 2010, 47, 421-431. [CrossRef]

121. Bayulgen, O. Oil Is Not a Curse: Ownership Structure and Institutions in Soviet Successor States. Political Sci. Q. 2012, 127, 178-180. [CrossRef]

122. Haber, S.H.; Menaldo, V. Do natural resources fuel authoritarianism? A reappraisal of the resource curse: Na. Am. Pol. Sci. Rev. 2011, 105, 1-26. [CrossRef]

123. Tsui, K.K. More oil, less democracy: Evidence from worldwide crude oil discoveries. Econ. J. 2011, 121, 89-115. [CrossRef]

124. Rajan, R.G.; Subramanian, A. Aid, Dutch disease, and manufacturing growth. J. Dev. Econ. 2011, 94, 106-118. [CrossRef]

125. Ramsay, K.W. Revisiting the Resource Curse: Natural Disasters, the Price of Oil, and Democracy. Int. Organ. 2011, 65, 507-529. [CrossRef]

126. Busse, M.; Gröning, S. The resource curse revisited: Governance and natural resources. Public Choice 2013, 154, 1-20. [CrossRef]

127. Dube, O.; Vargas, J.F. Commodity Price Shocks and Civil Conflict: Evidence from Colombia. Rev. Econ. Stud. 2013, 80, 1384-1421. [CrossRef]

128. Andersen, J.J.; Aslaksen, S. Oil and political survival. J. Dev. Econ. 2013, 100, 89-106. [CrossRef]

129. Andersen, J.J.; Ross, M.L. The Big Oil Change. Comp. Polit. Stud. 2014, 47, 993-1021. [CrossRef]

130. Wiens, D. Natural resources and institutional development. J. Theor. Pol. 2013, 26, 197-221. [CrossRef]

131. Ahmadov, A.K. Oil, Democracy, and Context. Comp. Polit. Stud. 2014, 47, 1238-1267. [CrossRef]

132. Wright, J.; Frantz, E.; Geddes, B. Oil and Autocratic Regime Survival. Br. J. Pol. Sci. 2015, 45, 287-306. [CrossRef]

133. Brooks, S.M.; Kurtz, M.J. Oil and Democracy: Endogenous Natural Resources and the Political "Resource Curse". Int. Organ. 2016, 70, 279-311. [CrossRef]

134. Le Billon, P. The political ecology of war: Natural resources and armed conflicts. Pol. Geogr. 2001, 20, 561-584. [CrossRef]

135. De Soysa, I. Paradise is a Bazaar? Greed, Creed, and Governance in Civil War, 1989-1999. J. Peace Res. 2002, $39,395-416$. [CrossRef]

136. Collier, P. Breaking the Conflict Trap: Civil War and Development Policy; World Bank Publications: Washington, DC, USA, 2003.

137. Ross, M.L. What do we know about natural resources and civil war? J. Peace Res. 2004, 41, 337-356. [CrossRef]

138. Collier, P. Greed and grievance in civil war. Oxf. Econ. Pap. 2004, 56, 563-595. [CrossRef]

139. Jensen, N.; Wantchekon, L. Resource Wealth and Political Regimes in Africa. Comp. Pol. Stud. 2004, 37, 816-841. [CrossRef]

140. Ross, M. How does natural resource wealth influence civil war? Evidence from Thirteen Cases. Int. Org. 2004, 58, 35-67. [CrossRef]

141. Smith, B. Oil wealth and regime survival in the developing world, 1960-1999. Am. J. Political Sci. 2004, 48, 232-246. [CrossRef]

142. Collier, P.; Hoeffler, A.; Söderbom, M. On the Duration of Civil War. J. Peace Res. 2004, 41, 253-273. [CrossRef]

143. Ross, M. A Closer Look at Oil, Diamonds, and Civil War. Annu. Rev. Political Sci. 2006, 9, 265-300. [CrossRef]

144. Badeeb, R.; Lean, H.H.; Clark, J. The evolution of the natural resource curse thesis: A critical literature survey. Resour. Policy 2017, 51, 123-134. [CrossRef]

145. Ross, M. What Have We Learned about the Resource Curse? Annu. Rev. Pol. Sci. 2015, 18, 239-259. [CrossRef]

146. Hutchins, B.I.; Yuan, X.; Anderson, J.M.; Santangelo, G.M. Relative Citation Ratio (RCR): A New Metric That Uses Citation Rates to Measure Influence at the Article Level. PLoS Biol. 2016, 14, e1002541. [CrossRef] 
147. Kleinberg, J.; Tardos, É. Approximation algorithms for classification problems with pairwise relationships: Metric labeling and markov random fields. JACM 2002, 49, 616-639. [CrossRef]

148. Brunnschweiler, C.N.; Bulte, E.H. The resource curse revisited and revised: A tale of paradoxes and red herrings. J. Environ. Econ. Manag. 2008, 55, 248-264. [CrossRef]

149. Ross, M.L. The Oil Curse; Princeton University Press: Princeton, NJ, USA, 2012.

150. Le Billon, P. Natural resources and corruption in post-war transitions: Matters of trust. Third World Q. 2014, 35, 770-786. [CrossRef]

151. Apergis, N.; Payne, J.E. The oil curse, institutional quality, and growth in MENA countries: Evidence from time-varying cointegration. Energy Econ. 2014, 46, 1-9. [CrossRef]

152. Bhattacharyya, S.; Collier, P. Public capital in resource rich economies: Is there a curse? Oxf. Econ. Pap. 2014, 66, 1-24. [CrossRef]

153. Anser, M.K.; Yousaf, Z.; Nassani, A.A.; Vo, X.V.; Zaman, K. Evaluating 'natural resource curse' hypothesis under sustainable information technologies: A case study of Saudi Arabia. Resour. Policy 2020, 68, 101699. [CrossRef]

154. Cockx, L.; Francken, N. Extending the concept of the resource curse: Natural resources and public spending on health. Ecol. Econ. 2014, 108, 136-149. [CrossRef]

155. Koubi, V.; Spilker, G.; Böhmelt, T.; Bernauer, T. Do natural resources matter for interstate and intrastate armed conflict? J. Peace Res. 2013, 51, 227-243. [CrossRef]

156. Hilmawan, R.; Clark, J. An investigation of the resource curse in Indonesia. Resour. Policy 2019, 64, 101483. [CrossRef]

157. Ampofo, G.K.M.; Cheng, J.; Asante, D.A.; Bosah, P. Total natural resource rents, trade openness and economic growth in the top mineral-rich countries: New evidence from nonlinear and asymmetric analysis. Resour. Policy 2020, 68, 101710. [CrossRef]

158. Deng, W.; Liang, Q.; Li, J.; Wang, W. Science mapping: A bibliometric analysis of female entrepreneurship studies. Gend. Manag. Int. J. 2021, 36, 61-86. [CrossRef]

159. Goerlandt, F.; Li, J.; Reniers, G. The Landscape of Risk Communication Research: A Scientometric Analysis. Int. J. Environ. Res. Public Heal. 2020, 17, 3255. [CrossRef] [PubMed]

160. Fong, E.A.; Wilhite, A.W. Authorship and citation manipulation in academic research. PLoS ONE 2017, 12, e0187394. [CrossRef]

161. Garfield, E. Is citation analysis a legitimate evaluation tool? Science 1979, 1, 359-375. [CrossRef] 